\title{
GEOLOGIA DA REGIÃO DO DOMO DO SUCUNDURI
}

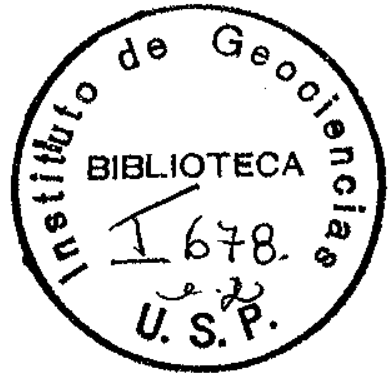

WOLDEMAR IWANUCH

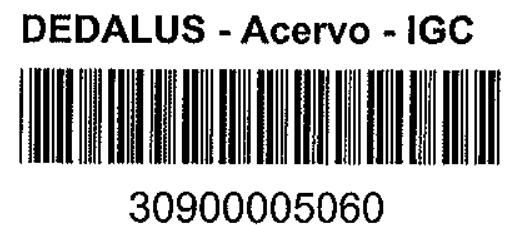

DISSERTAÇÃO DE MESTRADO

APRESENTADA AO INSTITUTO DE GEOCIENCIAS DA

UNIVERSIDADE DE SAO PAULO

ORIENTADOR

Prof. Dr. UMBERTO G. CORDANI 
I. INTRODU'ÇAO

I.1. Apresentação e objetivos

I.2. Localização da ärea

I.3. Acesso

I.4. População

I.5. Fisiografia

I.5.1. C1 ima

I.5.2. Vegetação

I.5.3. Drenagem

I.5.4. Geomorfologia

II. METODOLOGIA

II.1. Levantamento Geológico de Superfície

II.2. Petrografia

II.3. Geocronologia

I I $: 3.1$. Mētodo Potāssio-Argônio

II.3.2. Mêtodo Rubĩdio-Estrôncio

III. HISTORICO E TRABALHOS PREVIOS

IV. GEOLOGIA REGIONAL E ESTRATIGRAFIA

V. GÉOLOGIA DA REGIAO DO DOMO DO SUCUNDURI

V.1. Complexo Xingu

V.1.1. Generalidades

V.1.2. Petrografia

V.1.3. Geocronologia

v.2. Grupo Vatumã

V.2.1. Generalidades

V.2.2. Petrografia

V.2.3. Geocronologia

V.3. Grupo Beneficente 
V.3.2. Petrografia $\quad 55$

V.3.3. Geocronologia 58

V.4. Suite Intrusiva Cinco Ithas $\quad \ldots 6$

V.4.1. Generalidades 61

V.4.2. Petrografia $\quad 64$

V.4.3. Geocronologia 64

V.5. Formação Prosperança $\cdots$

V.5.1. Generalidades 68

V:5.2. Petrografia 68

V.5.3. Idade ${ }^{\circ} 68$

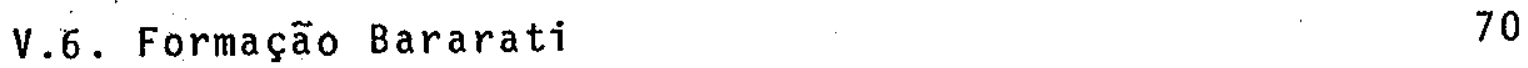

V.6.1. Generalidades $\quad 70$

$\begin{array}{ll}\text { V.6.2. Idade } & 70\end{array}$

$\begin{array}{ll}\text { V.7 : Magmatismo Bāsico } & 70\end{array}$

V.7.1. Generalidades $\quad 70$

V.7.2. Petrografia 71

V.7.3. Geocronologia 71

VI. COMPARTIMENTAÇACO TECTONICA DA REGIAO DO DOMO DO SUCUN DURI

VI.1. Generalidades 75

VI.1.T. Bloco Camaiü $\quad 75$

VI.1.2. Bloco Acari 77

VI.1.3. Bloco Aripuanā 77

VI.1.4. Bloco Matrinchão 79

VI.1.5. Bloco Juruena 79

VI.1.5.1. Domo do Sucunduri 80

VI.1.5.2. Sinclinal Sucunduri-Bararati 81

VI.1.5.3. Anticlinal do Juruena 81

VI.1.5.4. Sinclinal do São Tomë 81

VIT 1.5.5. Anticlinal Mundurucus 82

VII. CONSIDERAÇOES FINAIS E CONCLUSOES 
BIBLIOGRAF IA CITADA

BIBL IOGRAFIA CONSULTADA

ANEXOS - DESCRIÇOES PETROGRAFICAS 


\section{TABELAS}

Tabela 1 - Dados analîticos Rb/Sr das rochas graniticas e granodioriticas do embasamento, bloco Matrinchão.

Tabela 2 - Dados anaifticos Rb/Sr das rochas gnaissicas do embasamento, bloco Aripuanã.

Tabela 3 - Dados analiticos K/Ar de rochas do embasamen to, bloco Aripuanã.

Tabela 4 - Dados analiticos Rb/Sr das rochas vulcānicas do rio Juruena.

Tabela 5 - Dados analiticos Rb/Sr dos granitos da região de Capivara, rio Juruena.

Tabela 6 - Dados analiticos Rb/Sr das rochas graniticas e vulcánicas da bacìa do rio Acari (bloco Acari).

Tabela 7 - Dados analiticos Rb/Sr das rochas graniticas e vulcânicas do domo do Sucunduri (bloco Juruena).

Tabela 8 - Dados analiticos $\mathrm{Rb} / \mathrm{Sr}$ em rocha total de ardō sias do Grupo Beneficente.

Tabela 9 - Dados analiticos K/Ar em rocha total de peli tos do Grupo Beneficente.

Tabela 10- Dados analiticos Rb/Sr das rochas ataalinas do domo do sucunduri.

Tabela 11 - Dados analiticos K/Ar das rochas alcalinas do domo do Sucunduri.

Tabela 12 - Dados analiticos K/Ar das rochas básicas.

\section{FIGURAS}

Figura 1 - Localização da ārea de estudo.

Figura 2 - Coluna estratigräfica regional. 
Figura 3 - Isōcrona de referência em rocha total dos granitos e granodioritos do embasamento do bloco Matrinchão.

Figura 4 - Isōcrona de referência em rocha total dos gnaisses do embasamento do bloco Aripuanã.

Figura 5 - Isōcrona de referēncia em rocha total das vulcânicas do rio juruena.

Figura 6 - Isōcrona de referência em granitos da região de Capivara, rio Juruena, bloco Matrinchão.

Figura 7 - Isōcrona de referéncia em rocha total das vulcânicas do bloco Acari.

Figura 8 - Isōcrona de referência em rocha total das vulcānicas do domo do Sucunduri.

Figura 9. - Isōcrona de referēncia em rocha total em ardósias do Grupo Beneficente.

Figura 10 - Isōcrona de referēncia em rocha total para as alcalinas do domo do Sucunduri.

Figura 11 - Compartimentação tectônica da região do domo do Sucunduri.

Figura 12 - Coluna éstratigrāfica da região do domo do sucunduri.

Figura 13 - Mapa de idades radiométricas

Figura 14 - Esboço geológico-estrutural da região do domo do Sucunduri. 
I. INTRODUÇAOO

I.1. Apresentação e objetivos

0 presente estudo deve ser considerado como uma contribuição adicional ao conthecimento da geologia da região ama zônica brasileira, ainda muito carente de dados geológicos,quando comparada às demais regiões do territörio nacional.

Com base nos dados de campo, dados bibliogräfi cos, trabalhos de laboratōrio, anālises geocronológicas e interpretação de imagens de radar procurou-se neste estudo estabele cer a sequéncia dos maiores eventos temporais com objetivo de esboçar a evolução geológica da ārea situada entre o domo do Sucunduri (sudeste do estado do Amazonas) e a região do baixo e médio rio Juruena (centro-norte do estado de Mato Grosso).

Para a consecução do objetivo acima exposto, foi realizado um mapeamento de carāter regional que permitiu definir os principais traços geológico-estruturais da região. Com os tra balhos auxiliares de petrografia microscópica foi possīvel carac terizar os principais tipos litológicos e selecionar as amostras que foram analisadas geocronologicamente.

A apresentação da sīntese dessas informações é a finalidade do presente trabalho, que teve injcio no ano de 1974, com as primeiras viagens do autor à região.

\section{I.2. Localização da ārea}

A ārea objeto deste estudo situa-se na porção centro-sul da Amazōnia brasileira e compreende terras dos munici pios de Borba, Nova Aripuanã e Aripuanä (Figura 1).

Os dois primeiros localizam-se no sudeste do Estado do Amazonas,e o ūitimo no centro-norte do Estado de : Mato Grosso. 


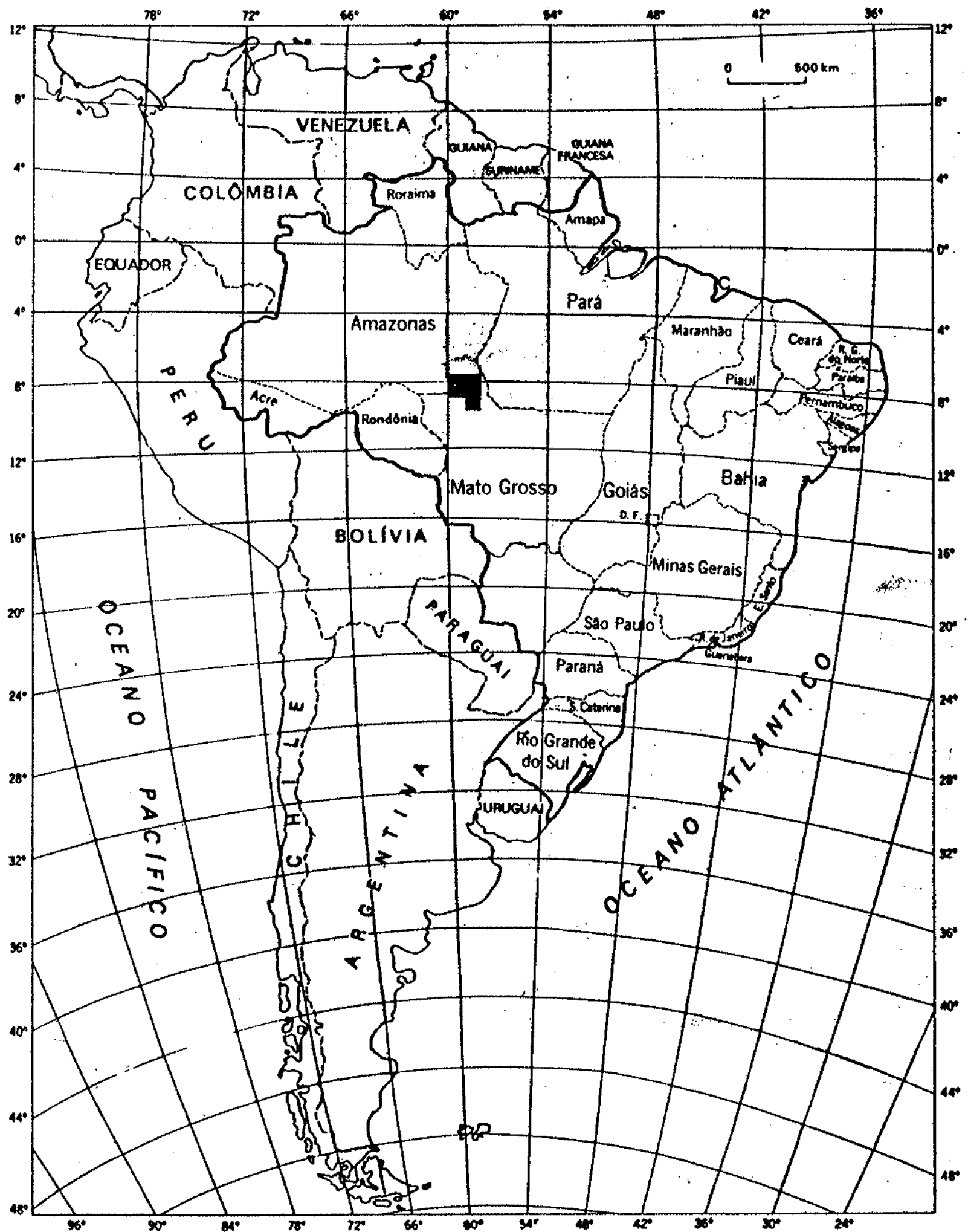

Figura 1́: Localizacão da Área de Estudo. 
1.3. Acesso

0 acesso à ārea em geral ē muito difícil, devido a sua localização em região invia e remota.

o setor norte e central é alcançado a partir do lugarejo de Santarenzinho que se situa no cruzamento do rio su cunduri com a rodovia Transamazónica. De Santarenzinho atinge-se a alta bacia do rio Sucunduri, atravēs do próprio rio, utilizando-se barcos de pequeno porte $(1,0$ a 1,5 toneladas $)$ com motor de popa, isto devido às inūmeras cachoeiras, rápidos e pedrais exís tentes no seu mëdio e alto curso.

o setor leste e sudeste da ārea, que corresponde ao curso inferior e mëdio do rio juruena, è alcançado por via fluvial em barcos de pequeno porte (com motor de popa), a partir da localidade de Porto dos Gauchos, situada na margem direita no rio Arinos que ē um dos tributários da margem direita do mëdio rio Juruena.

\section{I.4. População}

A ārea ē um verdadeiro vazio demogrāfico, habita da somente por diminutos, raros e esparsos nūcleos de população ribeirinha dedicada ao extrativismo vegetal e animal. Como núcleos populacionais sedentārios aparecem o de Terra Preta no rio Sucunduri e o de Jacaretinga no rio Aripuanã. Aparecem ainda con tingentês flutuantes de garimpeiros nas äreas interiorizadas junto aos garimpos de ouro do Arquimedes e Moreru.

\section{I.5. Fisiografia}

I.5.1. Clima

0 clima da região ē o quente e úmido de monções da Hilēia Amazōnica (IBGE, 1972), correspondendo na classificação de Koeppen, ao tipo de Am (Liberatore et al., 1972) caracterīstico de toda região do Alto Tapajós. Aparecem duas estações 
climáticas bem distintas, ou seja, seca de inverno-primavera (verão amazōnico) e chuvas de verão-outono (inverno amazōnico), com máximo em fevereiro ou março.

0 pérīodo mais quente corresponde aos meses de se tembro-outubro com valores absolutos máximos de $390 \mathrm{C}$, enquanto que a temperatura mēdia anual è de $250 \mathrm{C}$. As temperaturas minimas absolutas descem atē valores de $80 \mathrm{C}$ no perīodo de inverno, por ocasião das invasões de ventos frios de massa polar (.anticiclones de origem polar) com trajetōria continental (IBGE, 1977a) causando o fenōmeno da friagem, caracterizado por bruscas quedas de temperatura, que perduram em mēdia quatro dias.

0 clima, de uma maneira gera 1 è extremamente. ümido, apresentando umidade relativa do ar superior a $80 \%$ durante 0 ano todo, enquanto as precipitações pluviomētricas apresentam valores mëdios anuais de $2570 \mathrm{~mm}$ (IBGE, 1977b).

0 regime dos rios estā intimamente ligado à incidência de chuvas. No período do inverno amazōnico, ou seja ēpoca das chuvas, o nīvel dos rios sobe consideravelmente, provocando a nualmente inundações de extensas āreas ribeirinhas. No verão amazônico o nîvel baixa gradualmente, atingido pontos mïnimos em outubro-novembro, ocasião em que o transporte fluvial em alguns rios $\vec{e}$ extremamente dificil.

\section{I.5.2. Vegetação}

A cobertura vegetal da ārea tem como unidades pre dominantes a floresta tropical aberta no setor norte, floresta densa no setor sul. Sobre a chapada do Cachimbo aparece a floresta de transição reunindo os diversos tipos de cerrados, floresta densa e aberta ( Silva et a1, 1974, Terezo et a 1., 1975).

$\mathrm{Na}$ floresta aberta, que ocorre na bacia do rio Sucunduri, aparecem no estrato emergente as seguintes espēcies vegetais: Jutaî (Hymenaea), abiorana (Pouteria sp), itaūba (Mazilaurus itauba), e castanheira (Bertholletia excelsa). Na sinūsia codominanté com cerca de $20 \mathrm{~m}$ de altura, encontramos matamatá (E 
schweilera coriäcea, Mart., Schlerolobium gaeldianum, Hub.).

Na floresta densa as espëcies mais comuns são: a seringueira (Hevea brasiliensis), a maçaranduba (Manilkara sp), a barriguda (Bombax sp), a castanheira (Bertholletia excelsa), o ce dro (Cedrela adorata) e o mogno (Swietenia macrophyle, Ducke).

No campo cerrado aparecem vegetais :pertencentes às famīlias das gramīneas, bromeliāceas e cyperāceas (Silva et a1., op.cit:). Finalmente, nas depressões fluviais, inundäveis pe riodicamente, aparece a floresta ciliar onde são comuns o aça $\vec{i}$ (Eu térpe sp.), a samaūma (Ceiba pentandra, L.Gaertn.), e a maparajuba (Mimusops amazônica, Hub,).

\section{I.5.3. Drenagem}

A ārea abrange parte das bacias dos rios Aripuanã, Sucunduri e Juruena. São três grandes rios, com cursos, em maior parte dirigidos de sul para o norte.

0 rio Aripuanã tem seus manadouros na serra Norte. E o maior afluente pela margem direita em territörio brasilej ro do rio Madeira. Seus principais afluentes na ärea pela margem direita são: igarapē Pacutinga, rio Moreru, rio Jacaretinga e o rio Maracanã.

0 rio Sucunduri nasce na ärea, nos confins meridionais do estado do Amazonas, prōximo aos seus limites com o de Mato Grosso. Apōs juntar-se ao rio Acari toma o nome de Canumã, indo desaguar no rio Amazonas. A alta bacia do rio Sucunduri tem forma alongada no sentido norte-sul, onde se destacam como afluen tes, pela margem direita o igarape do Assunção e pela esquerda o rio Urucu. De acordo com a divisão estabelecida para o rio sucunduri em termos de navegabilidade, o alto. Sucunduri vai da cachoei ra do Inferno atē as nascentes, trecho em que è navegāvel somente com pequenos barcos a motor de popa.

O rio Juruena nasce no bordo oriental de chapada dos Parecis no oeste do estado de Mato Grosso. No seu baixo curso 
ao se juntar com o rio Teles Pires, toma o nome de Tapajōs. Na ärea que compreende o trecho inferior do mëdio e baixo curso do rio Juruena tem como principais afluentes os rios São João da Barra (Matrinchão) e São Tomë pela margem direita, e o igarapē (rio) Bararati pela' margem esquerda.

\section{I.5.4. Geomorfologia}

De acordo com os dados de "Silva et al.(1974) e Ventura et al (1975), a região apresenta de uma maneira geral duas grandes expressões geomorfolōgicas. A primeira delas compreende uma extensa ārea dissecada com pequenas altitudes, situada ao sul e sudoeste da chapada do Cachimbo. Nesta ärea arrasada,constituida predominantemente de rochas do embasamento o relevo è representado por colinas suavemente abauladas, recobertas por espesso manto de intemperismo. Quebram a monotonia da paisagem raros morros sem vegetação, prōprios da alteração por exfoliação de rochas graniticas.

A segunda grande "expressão geomorfolögica a cha pada do Cachimbo, caracteriza-se por uma região elevada de serras, chapadas, mesas e cuestas. Constitui um conjunto de relevos dissimētricos, englobando duas partes morfologicamente distintas, serras e chapadas, que se desenvolvem sobre rochas sedimentares do Grupo Beneficente, Formação Prosperança e pōs-Prosperança. As chapadas que constituem a forma de relevo dominante na ārea, aparecem com altitudes variando de 150 a 400 m. e com caimento na direção NW-SE. As serras aparecem na região do rio sucunduri, in cluindo relevos dissecados em cristas, colinas de topo aplainado, vales encaixados e ravinas.

$\mathrm{Na}$ região do igarapē Bararati, que se superimpōs a sinclinal homōnima, aparecem relevos estruturais, que se ressaltam pelo alinhamento dos "hogbacks" e residuais tabuliformes escarpados.

No baixo rio Juruena a chapada do Cachimbo e caracterizada por uma extensa superficie de aplainamento. 
Surgem ainda com destaque morfológico-topogrāfico diques de diabāsio, formando relevo de cristas com direções pre ferenciais NE-SW e NW-SE. 
II. METODOLOGIA

II.1. Levantamento Geolögico de Superfície

Os trabalhos de geologia de superfície foram reali zados consoante a metodologia usual para levantamentos dessa natu reza.

os seguintes elementos cartogräficos foram utiliza dos como base dos trabalhos:

- Cartas planimétricas em escala 1:250.000 do Projeto RADAM/DNPM-MME, folhas SB.21-V-C Rio Sucunduri, SB.21-V-D Rio Juruena, SC.21-V-A Aripuanã, SC.21-V-B Rio Teles Pires, SC. 21-V-C Bom Sucesso, SC-21-V-D Rio Apiacā.

- Mosäicos semi-controlados de Radar em escala 1.250.000 do Projeto RADAM/DNPM-MME folhas SB.21-Y-C Rio Sucundu $r i, S B .21-Y-D$ Rio Juruena, SC.21-V $\div$ A Aripuanã, SC.21-V-B Rio Teles Pires, SC.21-V-C. Bom Sucesso e SC.21-V-D Rio Apiacā.

- Mosäicos semi-controlados de Radar em escala $1: 1.000 .000$ do Projeto RADAM/ONPM-MME, folhas SC.21.Juruena e SB. 21 Tapajōs.

- Mosaicos semi-controlados de Radar ampliados para escala 1:700.000, Folhas SB.21-Y-C, SB.21-Y-D, SC.21-V-A, SC. $21-V-B, S C .21-V-C$ e SC.21-V-D.

- Mapa Geológico do Projeto RADAM/DNPM-MME Folha SB.21 Tapajōs, em escala 1:1.000.000.

As observações de campo foram feitas em vārias eta pas ao longo de rios e em piques abertos na mata, e sempre durante o fim do verão amazônico (perīodo da seca) quando as àguas nos rios descem aos nīveis minnimos propiciando assim estudo de um nūmero maior de afloramentos.

Em gera1, os afloramentos rochosos nos rios são 
esparsos e descontīnuos, formam lajedos e blocos,sãos ou parcialmente intemperizados. Jä os de terra firme, alêm de raros, formam matacões arredondados, soltos e profundamente alterados, havendo portanto, grande dificuldade para se obter amostra fres ca.

Durante a fase de campo, como mapa-base foram em pregados mosáicos ampliados semi-controlados de radar na esca la de 1:100.000, que permitiram uma boa identificação e controle dos pontos amostrados nos levantamentos a tempo e büssola nos rios, trena e büssola em terra, efetuados conforme a metodologia descrita em Rosa et a1: (1966).

Os dados geolögicos de campo obtidos somados aos de Almeida e Nogueira (1959), Liberatore et al (1972), Silva et al (1974) e os fornecidos pela Cia. Administradora Morro VermeTho, e pela Mineração Itaiba S/A juntamente com os de interpreta ção de mosäicos semi-controlados na escala de 1:250.000, permiti ram elaborar um mapa (esboço geolögico estrutural) na escala de $1: 500.000$.

A toponimia citada no texto e apresentada nos mapas, baseia-se nos nomes constantes na carta do Brasil ao Mi lionēsimo; folhas SB.21 Tapajōs e SC.21 Juruena do Instituto Bra sileiro Geografia e Estatīstica (IBGE, 1972) e nas cartas planimëtricas SB.21-Y-C, SB.21-Y-D, SC.21-V-A, SC.21-V-B, SC.21-V-C e SC.21-V-D do Projeto Radam (1974).

\section{II $\div 2$. Petrografia}

Foram estudadas petrograficamente cerca de 230 secções delgadas de rochas representativas da região, bem como descritas megascopicamente as amostras coletadas.

As anālises petrogrāficas foram efetuadas consoante tēcnicas convencionais. São semiquantitativas, posto que não foram executadas as anälises modais, atravēs de contagem de pontos com platina integradora ou equipamento similar. 
dados minerajógicos e estruturais, tanto de campo quanto de secções delgadas. A classificação quanto aos aspectos estruturais baseou-se na nomenclatura de Mehnert (1971), no entanto sem cono tações genēticas.

Para a classificação das rochas alcalinas utịizou-se a nomenclatura de Johannsen $(1931$, 1938) e para as demais rochas igneas a terminologia de Streckeisen (1967, 1976).

As rochas cataciästicas foram descritas de acordo com Higgins (1971).

A terminologia das rochas sedimentares baseou-se na encontrada em Pettijohn et al (1972), enquanto das bioclásticas deve-se a classificação de Folk (1959).

\section{II.3. Geocronologia}

Durante os trabalhos de campo efetuou-se uma :amostragem adequada das diversas litologias pertencentes as unida des maiores da região com vistas aos trabalhos de geocronologia.

As determinações geocronolōgicas foram efetuadas pelo mētodos Potāssio-Argōnio (em minerais separados e rocha tota1) e Rubĩdio-Estrōncio(em rocha total com amostras cogenēticas para interpretações em diagramas isocrōnicos).

\section{II.3.1. Mētodo Potāssio-Argônio}

As tëcnicas analīticas e a precisão experimentaldo mētodo potāssio-argōnio utilizado no Centro de Pesquisas Geocronolögicas, foram descritas com minudências por Amaral . et:al. (1966), e por Cordani (1970).

As amostras que apresentavam textura fina e gran de imbricamento dos grãos, nas quais a separação dos minerais não era viāvel, foram preparadas em rocha total (gabro, olivina diabāsios, fonōititos, traquitos e latitos) por britagem, moagem 
e separação por peneiramento dos grãos retidos entre as malhas de 60 - 100 meshes. 0s concentrados monominerälicos, (biotita e anfibōlio) foram preparados a partir de frações granulométricas homogēneas obtidas por britagem, moagem e peneiramento, que foram beneficiados por mëtodos físicos utilizando-se separador ele tromagnētico Franz, lĩquidos pesados e placa vibratōria.

As dosagens de potāssio foram realizadas em duplicata por fotometria de chama com padrão interno de lítio, e por espectroscopia de absorção atômica.

As extrações de argônio foram realizadas em $1 i$ nhas de ultra-alto vācuo com pressões da ordem de $10^{-8} \mathrm{~mm} \mathrm{Hg}$. 0 gās extraĩdo apōs a fusão da amostra em forno de indução,a tempe raturas da ordem de $12000 \mathrm{C}$, era purificado em fornos de cobre e titânio. A cada extração foi adicionada uma quantidade conbecida do isōtopo $\mathrm{Ar}^{38}$. A anāilise isotōpica da mistura gasosa purificada foi efetuada em espectrōmetro de massa tipo Reynolds.

As constantes utilizadas no cálculo de idade fo ram:

$$
\begin{aligned}
& \lambda \beta=0,496 \times 10^{-9} \operatorname{anos}^{-1} \\
& \lambda \varepsilon=0,581 \times 10^{-10} \text { anos }^{-1} \\
& \% \text { atômica de } K^{40} \text { em } K \text { total }=0,1167 \\
& \% \text { atōmica de } K^{39} \text { em } K \text { total }=93,258 \\
& \mathrm{Ar}^{40} / \mathrm{Ar}^{36}=295,5
\end{aligned}
$$

As idades foram calculadas em computador eletrōnico Burroughs 3500 do Centro de Computação Eletrônica da Univer sidade de São Paulo, utilizando-se o programa DARGON (Kawashita, 1972), que fornece os erros analiticos das datações, baseado na Teoria de Propagação dos Erros.

Os erros experimentais foram calculados em cada. caso, e no geral situam-se abaixo de $3 \%$, vide tabelas $3,9,11$ e 12 . 
-se em Dalrymple e Lamphere (1969).

\section{II.3.2. Mētodo Rubĩdio-Estrôncio}

0s procedimentos analīticos do mētodo rubïdio-es trôncio foram descritos por Torquato (1974) enquanto seus fundamentos teöricos podem ser vistos em Faure e Powell (1972) e Powe11. (1977).

Apōs o estudo petrográfico e eliminação das rochas alteradas (intemperizadas), as amostras escolhidas passaram por uma nova seleção baseada nas relações $\mathrm{Rb}^{\text {tot }} / \mathrm{Sr}^{\text {tot }}$ obtidas a partir de anālises semi-quantitativas de Rb e $\mathrm{Sr}$ por fluorescência de raios-X.

As amostras que apresentaram valores $\mathrm{Rb}^{\text {tot }}$ ou srtot inferiores a $40 \mathrm{ppm}$ nas dosagens quantitativas por fluores cência de raios-x, foram reanalisadas por diluição isotópica.

As anāitises isotópicas dos elementos Rb e $\mathrm{Sr}$ fo ram realizadas no espectrōmetro de massa, de fonte sōilida, TH-5 da Varian-Mat, cujas características encontram-se descritas em Torquato (op.cit.). Os valores de $5 r^{87} / \mathrm{sr}^{86}$ foram normalizados para $5 r^{86} / \mathrm{sr}^{88}=0,1194$.

As demais constantes utilizadas nos cālculos fo-

ram :

$$
\begin{aligned}
& \lambda_{R b}=1,42 \times 10^{-11} \text { anos }^{-1} \\
& \left(R b^{85} / R^{87}\right)_{N}=2,6039 \pm 0,0047 \\
& \left(R b^{85} / R^{87}\right)_{S}=0,01861 \pm 0,00003 \\
& \mathrm{gS}^{87}=0,03198 \pm 0,00004 \mathrm{kmoles} / \mathrm{g}
\end{aligned}
$$

Os cálculos de idades foram efetuadas por meio de computador eletrōnico Burroughs 3500 do Centro de Computação Eletrónica da Universidade de São Paulo. 
As determinações $\mathrm{Rb} / \mathrm{Sr}$ convencionais foram realiza das mediante a utilização dos programas DRBSR, quando analisados por diluição isotōpica, e DRSRN quando tratava-se de anālises de Sr normal, ambos desenvolvidos no CPGeo. E na elaboração de isócronas pelo mëtodo Nicolaysen (1961) foi empregado o programa Pisody de York (1966) modificado por Kawashita (1972), que permite o traçado da melhor reta, considerando-se os mīnimos quadrados cübi cos, bem como, calcula a variança mëdia quadrática ponderada ou MSWD (mean square weighted desviates), que dā o grau de colineari dade das amostras analisadas. Os erros apresentados, foram calculados considerando-se o desvio dos pontos analiticos em relação à melhor reta calculada.

De modo a uniformizar os dados radiométricos, para fins de interpretação, os valores analiticos de trabalhos anterio res que utilizaram a constante $\lambda_{R b}=1,47 \times 10^{-11}$ anos $^{-1}$, foram recalculados empregando-se a constante $\lambda_{\mathrm{Rb}}=1,42 \times 10^{-11}$ anos ${ }^{-1}$ conforme proposta de Steiger e Jüger (1978), o que acarreta um incremento de $3 \%$ no valor da idade..

A interpretação dos dados radiomētricos de rochas igneas e metamōrficas baseou-se em Faure e Powell (op.cit.), Faure (op.cit.), e de rochas sedimentares em Gebauer e Grunenfelder (1974) e Cordani et al (1978), que discutem amplamente todos problemas relacionados.

Com os dados geocronológicos obtidos foi elaborado um mapa de idades radiométricas baseado em Wanless (1969). 
III. HISTORICO E TRABALHOS PREVIOS

0 primeiro trabalho na ārea remonta a primeira me tade do sēculo XIX, sendo atribuĩdo a expedição Langsdorff, que entre 1828 e 1829, desceu os rios Preto, Arinos, Juruena e. Tapa jōs,com o. fito de estudar a sua flora, fauna, etnografia, geogra fia e geologia (Florence, 1875a e 1875b; Manizer, 1967). Seguem -se os estudos do explorador inglês Witliam Chandles (1862), que tambēm desceu os rios Arinos, Juruena e Tapajōs, fazendo vārias determinações astronōmicas e algumas observações geolōgicas. No fim do século passado Henri Coudreau (1897) fez o levantamento do rio Tapajōs e dos seus acidentes, desde Itaituba até o Salto Augusto no rio Juruena. De um modo geral estes trabalhos apresentam poucas referências geológicas.

Em 1926, Moura (1932) investigando o médio e alto rio Tapajōs, subiu o rio Juruena desde a sua foz atē a barra do rio são Tomé, descrevendo nesse trecho calcārios associados a arenitos. Dessa época, atē o final dos anos sessenta a região esteve totalmente abandonada.

Em 1972 Liberatore et al. apresentou o relatōrio final do Projeto Aripuanã-Sucunduri, descrevendo a geologia, es tratigrafia e recursos minerais das bacias dos rios Aripuanã e Sucunduri. Posteriormente Silva, Leal et al. (1974) e Santos et a1. (1975) publicam respectivamente os resultados do mapeamento das Folhas SC.21 Juruena e SB.21 Tapajös.

Ao lado desses trabalhos de carāter regional que incluem a ārea, cabe ressaltar ainda,os efetuados em āreas vizinhas, e que são de interesse para a estratigrafia e evolução geo lógica regional. Assim, Almeida e Nogueira Filho (1959) reconhecem o rio Aripuanã desde a sua foz atê a cachoeira de Dardanelos, descrevem e sua geologia, e definem o Grupo Beneficente, a Formação Dardanelos e a Formação Prainha.

Caputo et a1. (1972) apresentam uma revisão da es tratigrafia da Sinēclise do Amazonas, discutindo a posição e no- 
menclatura das rochas sedimentares e vulcānicas prē-cambrianas.

Silva, Lima et al. (1974) dividem o Grupo Uatumã proposto por Caputo et al (op.cit.) em trēs unidades defini das na ārea das Folhas SB.22 Araquaia e SE.22 Tocantins (Formação Iriri, Brasi1, Sudam, 1972; Formação Sobreiro, Parā, IDESP, 1972 e Formação Rio Fresco, Barbosa et al. 1966).

Dentre os vārios trabalhos de sintese apresenta dos nos ültimos anos para a região Amazônica cabe citar os de:

Suszczynski (1970) que apresenta um esquema da evolução tectōnica da Amazōnia, e define a Plataforma Amazōnica.

Almeida (1974 e 1976) e Almeida et al (1976)con sidera que o processo de consolidação do Cräton Amazônjco (Guaporé) apōs o Ciclo Transamazōnico foi progressivo, demorado e acompanhado de um vulcanismo äcido a intermediärio com plutonis mo cō-magmätico e relaciona as coberturas sedimentares à fase final e posterior do vulcano-plutonismo do Grupo Uatumã.

Amaral (1974) apresenta um trabalho sobre evolu ção tectōnica prē-cambriana da região Amazōnica, e descreve três eventos vulcano-plutōnicos denominados Paraense (1700 m.a.), Madeirense $(1300 \mathrm{~m} . \mathrm{a}$.$) e Rondoniense (1000 \mathrm{m.a.})$, relacionados a reativações da plataforma apōs o Ciçlo Transamazōnico:

Issler (1977) publica um trabalho de sintese da geologia e tectônica do Cräton Amazônico (Guaporé), e descreve detalhadamente os granitos do Grupo Uatumã, os quais define como corpos intrusivos, subvulcānicos, circulares e cratogèni cos.

Basei (1977, 1978) no seu vasto estudo geocrono lögico do vulcanismo ācido intermediārio da região amazōnica, de fine quatro eventos vulcānicos: Surumu-Iricoume $(1859 \pm 24 \mathrm{~m} . \mathrm{a})$, Uatumä-Iriri $(1715 \pm 32 \mathrm{m.a.})$, Teles Pires-Trā̄ra $(15 \overline{6} 1 \pm 38$

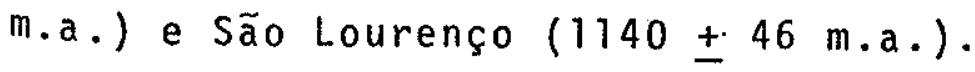


Cordani et al. (1978) apresentam um modelo de evolução do prē-cambriano da região amazōnica, segundo o qual, o desenvolvimento geodināmico da crosta continental è devido a atuação em ēpocas sucessivas de três cinturões mōveis "mobile belts" perifēricos (Maroni-Itacaiunas, 2200-1800 m.a.; Rio Negro -Juruena, 1700-1400 m.a. e Rondoniano, 1400-1100 m.a.) a uma mega-região de vocação cratōnica de idade transamazônica ou mais antiga (Provincia Amazônia Central).

Tassinari et.al. (1978) descrevem a cronoestrati grafia da região das chapadas do Cachimbo e Dardanelos, baseando - se em dados geocronológicos.

Montalvão et al. (1979) vinculam as rochas plutô nicas ācidas, intermediärias e alcalinas das folhas SB.20, SC. 20 e SC.21 e estāgios de semi-estabilização, estabilização e pōsestabilização da Plataforma Amazōnica.

Montalvão e Bezerra (1980) reavaliam e sinteti zam os dados de geologia e tectōnica da Plataforma Amazōnica obtidos pelo Projeto Radam afirmando que a partir de 1900-1800 m.a. não hā registros de formação de cinturões metamōrficos, e relacionam o vulcano-plutonismo final do Grupo Uatumã a reativação da plataforma.

Tassinari (1981) caracteriza geocronologicamente a Provincia Rio Negro-Juruena de Cordani et.al. (op.cit.) propondo uma evolução geotectōnica, baseada no desenvolvimento de "mobile belt" apoiada na Tectónica de Placas. 
IV. GEOLOGIA REGIONAL E ESTRATIGRAFIA

0 esbôço da geologia regional abaixo apresentado refere-se a porção territorial situada entre os paralelos 05000' a 11000' Lat.S e meridianos de 56000' a 60000' W.Gr. Segundo A1meida et al. (1974) o referido trato, situa-se bem no interior da Plataforma Sul Americana, mais especificamente no segmento sul do Cräton Amazónico, denominado de Escudo Brasil Central ou ainda no segmento sul da Plataforma Amazónica de acordo com a acepção de Suszczynski (1970).

0 embasamento é genericamente englobado no Complexo Xingu, definido por Silva, Lima et al. (1974), que aparece em duas āreas distintas, uma ao norte e outra ao sul da chapada do Cachimbo, que os separa geograficamente e que serão apresentados separadamente.

0 que ocupa a porção norte, estende-se de SE a NW, desde as cabeceiras dos rios Novo, Crepori, e o das Tropas, bordejando ao sul as faldas da chapada do Cachimbo atē os manadouros do rio Curuai, afluente da margem direita do rio Abacaxis, onde desaparece sob os sedimentos da Formação Prosperança.Santos et a1.(1975) descrevem o Complexo Xingu na Folha SB.21 Tapajós como constituĩdo por uma associação petrotectōnica granītico-ada melitica, com variações a granodioritos, gnaisses, migmatitos, di oritos, anfibolitos, enclaves de xistos, cataclasitos e possivel mente rochas granuliticas. Idades radiométricas obtidas nessas rochas tem fornecido valores superiores a $2000 \mathrm{~m} . \mathrm{a}$.

Juntam-se a esta associação petrotectōnica, que se apresenta no fäcies almandina-anfibolitica no sentido de Winkler (1967), corpos de granitos de remobilização reomörfica denominadas de Granito Parauari, que constituem estruturas zonadas com lineamentos anelares concēntricos, nem sempre circulares, elipsoidais ou fusóides, descritos por silva e Santos (1966) in Santos et al. (op.cit.), como granito pörfiro ou alcali granito leucocrático com textura porfiritica. Estes granitos aparecem na bacia do alto rio Parauari e no interflúvio dos rios pacue das Tropas. Ainda, segundo Santos et al. (op.cit.) o Granito Parauari 
estaria sucedendo estratigraficamente o Complexo Xingu, e perten ceria a fase tardia do Ciclo Transamazónico, definido por Hurley et a 1 . (1967).

Colocando-se estratigraficamente acima temos a sequência vulcānica-sedimentar da Formação Iriri, denominação proposta por BRASIL/SUDAM (1972), que constitui a unidade supe rior do Grupo Uatumã, segundo a definição de Silva, Lima et al. (op.cit.). A Formação Iriri inclui rochas vuicānicas de carāter äcido-intermediärio, bem como rochas sedimentares associadas. Seus principais tipos petrogräficos são: riolitos, riodacitos, daci tos, andesitos, granófiros, tufos, ignimbritos e rochas sedimentares, grauvacas e subgrauvacas. Suas maiores exposições loca lizam-se no flanco leste da ärea analisada, na calha do mēdio rio Novo. Segundo Basei (1977) os vulcanitos da Formação Iriri apresentam idades $\mathrm{Rb} / \mathrm{Sr}$ em isōcronas de referēncia de $1756 \pm 72$ m.a.

Associados e sucedendo o paroxismo äcido fissural ocorrem corpos granitticos intrusivos, subvulcānicos, cratogêni cos, com feições aneliformes, circulares e elipsōides, que foram denominados de Granito Maloquinha por Santos et al. (op.cit.). Issler (1977) relata que são em geral granitos pörfiros e porfi ríticos grosseiros, com pequena porcentagem de mäficos, em geral biotita, de tendência alasquîtica atē composição granodiorîtica.. Idade radiomētrica obtida em isōcrona de referéncia $R b /$ Sr em rocha total, acusou idade de $1708 \mathrm{m.a}$. (Basei, 1974a, in̈ Issler, op:cit.). Esse valor, aliado aos dados de campo e data ções däs vulcānicas da Formação Iriri, permite supor que ambos estão em estreita associação vulcanomplutōnica (Santos op.cit.).

Todas unidades anteriores são recobertas,

em não conformidade, pelos sedimentos do Grupo Beneficente, que cobrem transversalmente toda parte central da ārea analisada. A unidade foi originatmente definida por Almeida e Nogueira Filho (1959), nas proximidades do povoado de Beneficente no rio Aripuanã. Os mencionados autores, reconheceram duas litofácies, uma inferior de natureza psamītica,constituida de quartzitos e ortoquartzitos, e uma superior de carāter pelitico,representada por 
ardōsias cinzentas e quartzitos. Liberatoré et al., (1972, in Issler, 1977), durante o Projeto Aripuanã - Sucunduri reconheceram no rio Sucunduri, no litofäcies inferior, representado por quartzitos e ortoquartzitos a presença de Itabiritos e siltitos de cor creme, cinza-escura, vermelha, bordó, finamente laminados e no litofácies superior, alēm das ardósias identificaram argili tos, desde cinza-escuro a preto, siltitos ardosianos cinza-escuro e folhelhos. A melhor exposição apresenta uma espessura de. $6 \mathrm{~m}$, onde predomina a ardósia sîtica, intensamente fraturada e perturbada, com os planos de fratura preenchidas com öxido de ferro'e manganēs.

A deposição do Grupo Beneficente parece ter sido inicialmente continental, passando depois progressivamente para condições marinhas transgressivas diferentes, como mostram as as sociações litológicas e num ambiente de plataforma. Como estrutu ras primärias de sedimentação apresenta marcas de onda e estrati ficação cruzada,que atestam um ambiente subaquätico de àguas rasas.

o sinclinörio Sucunduri-Bararati e o domo do Sucunduri, anticlinōrio do Juruena e sinclinörio São Tomē são as feições tectōnicas mais pronunciadas no Grupo Beneficente. Apare cem ainda pequenas estruturas dômicas no interfīuvio Juruena-Teles pires. 0 domo do Sucunduri è uma impressionante estrutura de carāter regional, de forma aproximadamente circular, que apresen ta mais de $75 \mathrm{~km}$ de diāmetro. Sua parte interna encontra-se muito erodida expondo rochas predominantemente vulcānicas.

Segundo Iwanuch (1976) ocorrem ainda a $\bar{\imath}$, rochas alcalinas que constituem "plugs", "necks", diques e pequenos der rames representados petrograficamente por nefelina sienitos, microsienitos, fonolitos, lusitanitos e traquitos.

A Formação Prosperança assenta-se discordantemen te sobre o Complexo Xingu, Grupo Uatumã e o Grupo Beneficente. Sua denominação formal como unidade litoestratigräfica foi proposta por Caputo et al (op.cit.) para representar uma sequéncia sedimentar de arenitos e siltitos, cuja. seção tipo está expos- 
ta no rio Negro, no igarapē Prosperança. Baseando-se em algas fós seis Sommer e Costa (1972, in Santos et al.op.cit.) :considera ram a Formação Prosperança como prē-cambriana superior a eopaleo zóica. Montalvão e Bezerra (1980) redefiniram-na como constituĩ da por arenitos arcoseanos, com intercalações de argilitos e sil titos vermelhos caracteristicos de um ambiente continental de se dimentação. Propondo ainda, a denominação de Prainha,para as coberturas de plataforma anteriormente mapeadas como : Prosperança pelo Projeto Radam nas Folhas SB.21 Tapajōs, SC.20 Porto Velho e SB. 20 purus.

Estes sedimentos afloram predominantemente no flanco NW da ārea, ao norte, a oeste e no centro do domo do Sucunduri, e na forma de remanescentes sobre o Complexo Xingu e Grupo Uatumã nos interflüvios dos rios Amanã e Tapajōs, Crepori, e Pacu, Jamanxim e Novo, nas cabeceiras do rio das Tropas; no flanco $W$ interno do domo do Sucunduri, na chapada do Cachimbo so bre o Grupo Beneficente, e no extremo sudoeste nas cabeceiras do igarapē Agua Branca.

As unidades retrocitadas, são atravessadas por rochas eruptivas de caräter básico, denominadas de diabäsio tipo cu ruru, pertencentes a Formação Penatecaua de Issler et al.(1974, in Santos, et al. 1975). O diabāsio tipo Cururu forma diques, com orientação predominantemente NNE e NNW. Alguns são de pequeria ex tensão, enquanto outros atingem värias dezenas de quilómetros. Sua distribuição $\vec{e}$ bem ampla, notando-se no entanto, uma concentração na região do domo do Sucunduri e nos interfiūvios dos rios Sucun duri-Juruena, e Cururu-Teles Pires, onde cortam o Grupo Beneficen te. Determinações radiomētricas acusam idades Jurässico-cretācicas para a Formação Penatecaua (Santos et al., op.cit.).

0 embasamento cristalino que aparece ao sul da chapada do Cachimbo, e que ocupa a parte central enordeste da Fo Tha SC.21, segundo Silva, Leal et a 1. (1974), Issier (1977), $\overline{\mathrm{e}}$ constituido por polimetamorfitos (gnaisses, migmatitos de composição granītica, granodioritica, tonalitica e sienitica e raros granulitos e granitos), que mantem continuidade fijsica e seme Thança litolögica com os metamorfitos das Folhas SB.21 Tapajōs, SB.22 Araguaia e parte da SC.22. Tocantins, as rochas metamörfi 
cas aparecem na sua maior parte metamorfizadas no fäcies anfibolito de Turner (1968) e se associam a corpos graniticos de remobilização reomōrfica, de conformação geomētrica fusiforme, ou eliptica, orientação NW-SE, e distribuição irregular, que foram denominados por Silva et al (op.cit.) de Granito Juruena.

Souza et al (1979) relatam que os granitos tipo Juruena, apresentam passagens gradacionais em termos de composição e estruturas com as litologias do Complexo Xingu. Portanto eles os consideram como produtos resultantes de fusões parciais em condições atectōnicas.

Tassinari et al (1978) estudaram geocronologicamente pelo método $\mathrm{Rb} / \mathrm{Sr}$ as rochas do embasamento da Folha $\mathrm{SC} .21$ Juruena, e obtiveram dois diagramas isocrōnicos. A isōcrona RbSr de referência formada por amostras procedentes da parte orien tal da ärea indicou idade de $1860 \pm 94 \mathrm{~m} . \mathrm{a}$., para uma razão inicial de $0,704 \pm 0,002$. Por outro lado, a formada por rochas amostradas na parté ocidental apresentou idade de $1728 \mathrm{~m} . \mathrm{a} . \pm 44$ m.a., com razão inicjal de 0,701 $\pm 0,001$. A idade obtida, foi considerada por Tassinari et al (op.cit.) como representativa da época de formação daquelas rochas.

Sobrepõem-se estratigraficamente ao Complexo Xin gu rochas vulcânicas, constituīdas litologicamente por riōijtos, riodacitos, dacitos, andesitos e pirociasticas. Estas rochas dis tribuem-se principalmente ao longo da borda sul da chapada do Cachimbo, numa faixa orientada NE-SW, com largura média de $30 \mathrm{~km}$, bem como no domo do Sucunduri. Dados radiométricos em isōcrona de referēncia acusaram idade de $1676 \pm 36 \mathrm{~m} . \mathrm{a}$. por Basei (1977).

Associam-se ao evento magmätico efusivo corpos granīticos de tendéncia alasquitica, denominados Granito Teles Pires por Silva,leal et a 1. (1974). Estes granitos apresentam-se na forma de corpos circulares, elipsóides e irregulares, com dimensões normalmente de stocks e caracterīsticas principalmente subvulcānicas (Montalvão, 1979). Dentre as variedades petrogräfi cas do Granito Teles Pires, Araujo e Dreher (1974), Montalvão (op.cit.) e Souza et al. (1979) destacam granitos normais, ortocläsio granitos, microgranitos, granitos pörfiros, granöfiros, rie 


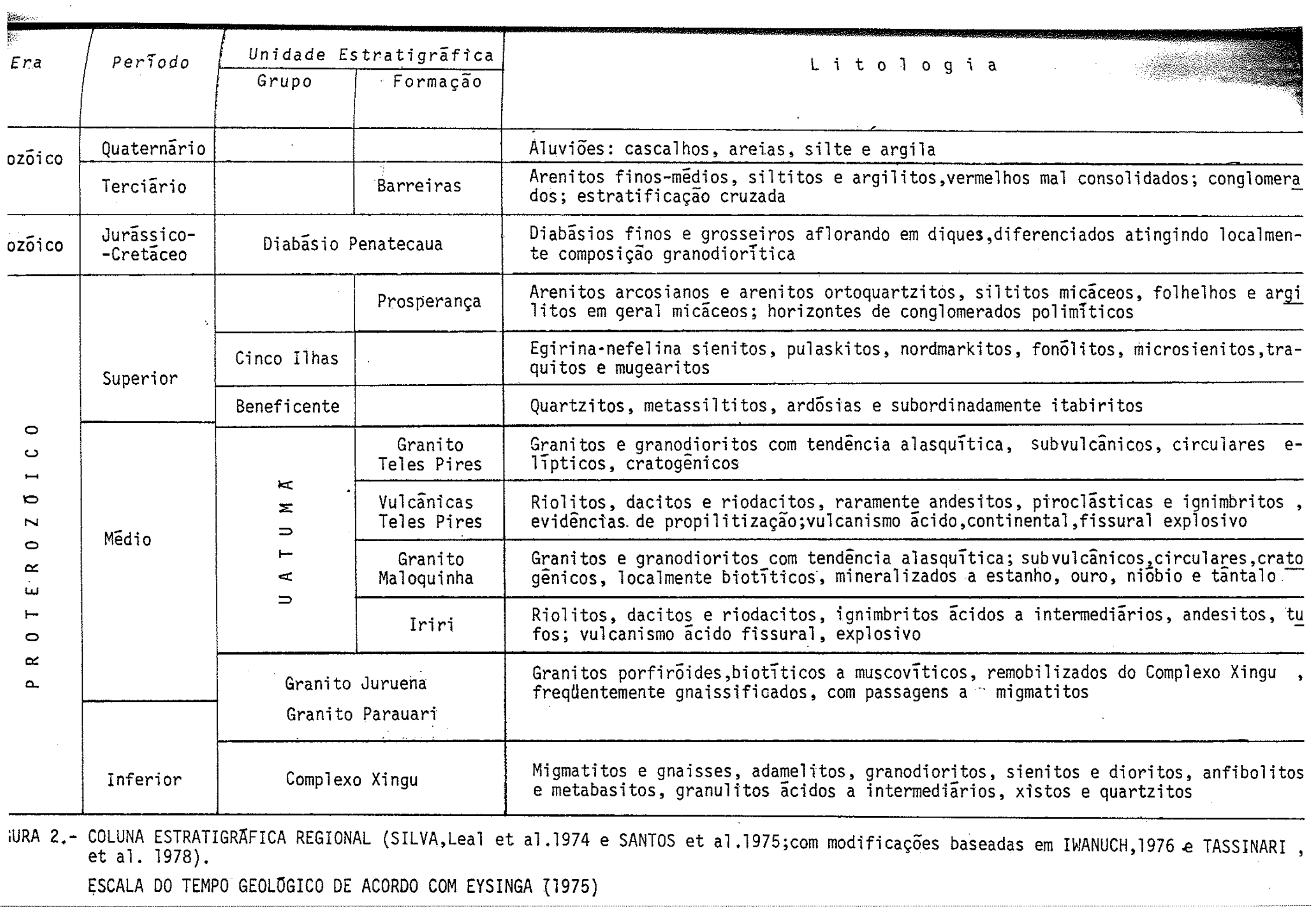


beckita granitos, e granitos com textura rapakivi (viborgitos e peterlitos). Os plutonitos Teles Pires tem larga distribuição geogräfica, aparecendo principalmente ao longo da faixa de rochas vulcānicas ao sul da chapada do Cachimbo, onde formam concentrações. Datações radiométricas efetuadas em granitos intrusi vos por Tassinari et al (op.cit.), pelo método Rb/Sr, acusaram em isōcrona de referēncia idade de $1602 \pm 30 \mathrm{~m} \cdot \mathrm{a}$. 
V. GEOLOGIA DA REGIAO DO DOMO DO SUCUNDURI

\section{V.1. Complexo Xingu}

\section{V.1.1. Generalidades}

A unidade geolögica mais antiga e mais heterogênea e que constitui o embasamento cristalino regional, correspon de ao assim denominado Complexo Xingu de Santos et al (op.cit.). Constitui-se de rochas igneas e metamōrficas de mëdio e alto grau de metamorfismo, que ocorrem sotopostas às demais unidades geológicas da região.

Ocupa predominantemente uma faixa de direção $N \underline{W}$ -SE na porção sul da ärea. Seus limites setentrionais estendem se do ocidente para o oriente, grosso modo paralelamente ao curso do rio Aripuanã até a sua curva na altura da localidade de Jacaretinga, onde segue bordejando o extremo sudoeste na chapada do Cachimbo, daī segue com a mesma direção até a tapera dos indios Canoeiros no rio Juruena, limitando-se com rochas vulcâni cas.

Suas exposições no rio Aripuanã, no trecho situa do entre o igarapē Goiabal e a cachoeira do Quebra Remo, segundo Almeida e Nogueira Filho (1959), são representadas por plutoni tos, granitos e granodioritos, com acentuados efeitos cataclásti cos. A montante da supradita cachoeira, aparecem gnaisses de : aspecto migmatitico, ao lado de outros de natureza granitica e granodioritica.

Por vezes, no interior da ärea gnäissica aparecem granodioritos, como na cachoeira do Pimenta. Esse corpo como os demais apresentam nitidas estruturas cataclästicas e miloniti cas. Ainda segundo os mesmos autores, as rochas metamörficas des sa faixa mostram a foliação com atitudes oscilando entre NW e WNW e mergulhos sempre muito fortes.

Na região do rio Juruena as melhores exposições aparecem ao sul da tapera dos indios Canoeiros. Desse ponto a 
montante atē o trecho norte da ilha Comprida, predominam granitos e granodioritos, secundariamente aparecem tonalitos, dioritos, metanoritos e gnaisses.

Os dioritos e metanoritos identificados constituem corpos provavelmente de pequenas dimensões, os quais devido a baixa frequência dos afloramentos e na ausēncia de feições tĩpi cas, contrastantes com as demais rochas da ārea nas imagens de radar, não foi possîvel isolar no mapa.

Da ilha Comprida para o sul ao longo do rio Juruena atē Ariel, gnaisses constituem a litologia dominante. Esses gnaisses são representados por muscovita e biotita gnaisses e qua se sempre mostram efeitos de cataclase. Tais feições sugerem a existência de uma larga ou de vārias zonas de falha pröximas. e subparalelas.

Ainda, no extremo meridional da ārea,prōximo a Ariel ocorrem biotita gnaisses com estrutura bandada e xistosidade bem desenvolvida, gradam para migmatitos que apresentam estruturas dobradas, ptigmāticas, schlieren, e que se acham localmente cortadas por filões aplïticos. Esses migmatitos passam através de nebulitos para um corpo granitico-granodioritico, que apresentá vênulas dobradas subparalelas de mäficos, normalmente de biotị ta.

Nesse trecho da região, a atitude da foliação metamörfica varia de local para local, demonstrando com isso que houve ou dobramentos, ou mais provavelmente um fraturamento mais ou menos intenso, produzindo blocos tectónicos de dimensões variā veis e com consequente basculamento a rotaçāo da foliação.

\section{V.1.2. Petrografia}

\section{Granitos}

Em amostras de mão são predominantemente porfir $\vec{i}-$ ticos com matriz fanerîtica mēdia à fina,e subordinadamente equigranular faneriticos de granulação mëdia e fina, leucocräticos. 
exibindo por vezes uma discreta orientação. Apresentam normalmente: cor cinza claro, que pode variar do cinza médio ao cinza rosado. os fenocristais são constituídos geralmente por plagioclásio cuja granulação varia de 1,0-3,0 mm. A matriz varia de fanerïtica fina $(0,05-0,2 \mathrm{~mm})$ à fanerītica mëdia $(1,0-3,0 \mathrm{~mm})$ formada norma 1 mente por microcīinio, plagiociásio, quartzo e máficos, como biotita, muscovita, hornblenda.Como acessōrios aparecem zircão, titanita, allanita, granada, apatita e como secundärios-sericita, epidoto, clorita, carbonato e agregados saussuriticos. As texturas da matriz em lâminas delgadas são essencialmente hipiomör ficas, tanto nos granitos equigranulares como nos porfiriticos.

\section{Granodioritos}

São macroscopicamente porfiriticos com matriz fanerïtica de granulação mēdia, leucocrāticos, por vezes exibem discreta orientação, de cor cinza mëdio. os fenocristais são constituīdos por plagioclásio e raramente por biotita. Os fenocristais de plagioclásio sistematicamente exibem zoneamento normal. A matriz apresenta granulação variável, por vezes equigranu lar, e raramente micropegmațtica, formada por plagiocläsio, microclinio, quartzo e biotita. Com acessōrios e secundários apare cem zircão, apatita, titanita, allanita, biotita verde e epidoto:

\section{Tonalitos}

Macroscopicamente são faneriticos, inequigranulares - de granulação mēdia à grossa, leucocrāticos, com máficos orientados e exibem cor cinza mëdio. 0 plagiocläsio presente ē zonado, tendendo a formar fenocristais de atē $1 \mathrm{~cm}$ em matriz granular de quartzo, plagioclásio e raro microclínio. Intersti cialmente acumulam-se muscovita, sericita, apatita e opacos. A composição modal estimada é plagiocläsio $50 \%$, quartzo $30 \%$, micro clînio 5\%, biotita e epidoto $12 \%$, e acessōrios $3 \%$. A textura da matriz è granular hipidiomōrfica. 
Gnaisses e Migmatitos

Estas rochas exibem à nīvel de afloramento estruturas gnaissico-migmatiticas caracteristicas, que podem segundo o seu aspecto ser divididas em dois grupos: migmatitos .. homogèneos (gnaisses Teucocräticos) de bandamento irregular e difuso, ou ausente frequentemente granoblästicos e migmatitos heterogé neos (gnaisses fitados) com estruturas bandadas, fitadas ou 1 istadas. De um modo geral predominam nessas rochas texturas granoblástica, granolepidoblástica, granoblästica interlobada e le pidogranoblästica, bem como flaser, augen-xistosa, blastocimentàda e blastomilonitica.

Quanto à composição mineralógica, as diferentes variedades litolögicas diferem apenas quanto à proporção relativa dos seus constituintes principais, apresentando termos de composição granïtica e granodiorītica.

A maioria das amostras investigadas exibem em lâaminas delgadas em grau variāvel feições de deformação e recrista lização. Assim, o plagiocläsio e o microclīnio aparecem na forma de olhos (porfiroclastos) reliquiares, arredondados ou lenticulares orientados segundo a xistosidade em matriz granular fina, ou formam agregados quartzo-feldspáticos com forma de ilhotas e lentes na outra mais fina; ou o quartzo, o plagioclásio e o microclinio aparecem deformados e lenticulares; ou os porfiroclastos de plagioclásio e microclīnio pertītico aparecem rodeados por fitas de quartzo muito deformado e faixas miloniticas;ou ainda o quartzo, o plagioclásio e microclīnio formam um agregado bastante deformado com grãos redondos ou lenticulares e nos intersticios fiapos bem orientados de muscovita (sericita) e bio tita. Alēm das feições supra mencionados aparecem ainda, intercrescimentos microscōpicos de quartzo vermicular com muscovita, pequenos grãos idiomorfos de plagioclásio nas bordas de cristais maiores com pontos triplos; pequenos grãos intersticiais de feldspato alcalino em volta de microclínio e oligociásio; grãos intercrescidos de plagioclásio e feldspato alcalino com pontos triplos. Cristais maiores de microclīnio incluindo grānulos de quartzo e plagiocläsio. O intercrescimento mirmequítico $\bar{e}$ uma 
constante em todas as amostras.

\section{V.1.3. Geocronologia}

As amostras selecionadas de granitos e granodioritos do embasamento, provenientes do bloco tectónico Matrinchão para estudo geocronolōgico pelo mëtodo Rb/Sr em rocha total cujos dados analiticos aparecem na Tabela 1, permitiram construir um diagrama isocrónico de referēncia (Figura 3 ) de 6 pontos que indicou idade de $1977 \pm 67 \mathrm{~m} . \mathrm{a}(2 \mathrm{o})$, para uma razão inicial $\mathrm{Sr}^{87} /$ $\operatorname{sir}^{86}=0,702 \pm 0,001$. A exceção do ponto analitico referente a amostra de nọ 9 (WI-J-66), que se colocou acima da reta isocrōnica e que não foi computado, os demais aparecem razoavelmente bem distribuĩdos, dispersos e colineares. Embora a reta isocrōnica não tenha nenhum ponto pröximo da origem do sistema de coordenadas $\mathrm{Rb}^{87} / \mathrm{Sr}^{86}-\mathrm{Sr}^{87} / \mathrm{Sr}^{86}$, que controle com maior exatidão à razão inicial, o baixo valor do MSWD 0,3276 confere-lhe significativa precisão. Ao lado desse cālculo de idade, foi efetuado um outro, no qual se incluiu a amostra de nọ 9 (Wi-J-66) e cuja iso crona acusou idade de $1914 \pm 90 \mathrm{~m} . \mathrm{a}$. ( $2 \sigma)$ para uma razão inicial $\mathrm{Sr}^{87} / \mathrm{Sr}^{86}=0,703 \pm 0,001 \mathrm{e}$ MSWD $=0,7038$. Dessa forma esses dois dados permitem sugerir o final do ciclo Transamazoñico como ēpoca de formação dessas rochas. Por outro lado, a amostra de no 11 (PT-07) representada por um gnaisse cataclasado e muito alterado com cerca de $30 \%$ de minerais secundärios, e cujo ponto analitico se coloca bem abaixo da reta isocrónica da Figura 2, apresenta idade convencional muito inferior ao conjunto men cionado, tambēm não foi computado no diagrama para călculo de idade.

As amostras de gnaisses situados no bloco Aripua nã entre a ilha Comprida e a localidade de Ariel no rio Juruena, tambēm foram estudados geocronologicamente e permitiram construir um outro diagrama isocrōnico de referéncia, que se acha representado pela Figura 3 e cujos dados analiticos encontram-se na Tabela 2. A isócrona obtida com 8 pontos analiticos, acusa idade de $1760 \pm 40 \mathrm{~m} . \mathrm{a}$. $(2 \sigma)$ e uma razão inicial de. 0,704 0,001 . Apresenta uma razoāvel dispersão dos pontos ana 7 iticos, sendo a razão inicial $\mathrm{Sr}^{87} / \mathrm{Sr}^{86}$ controlada pelo ponto de no 13 


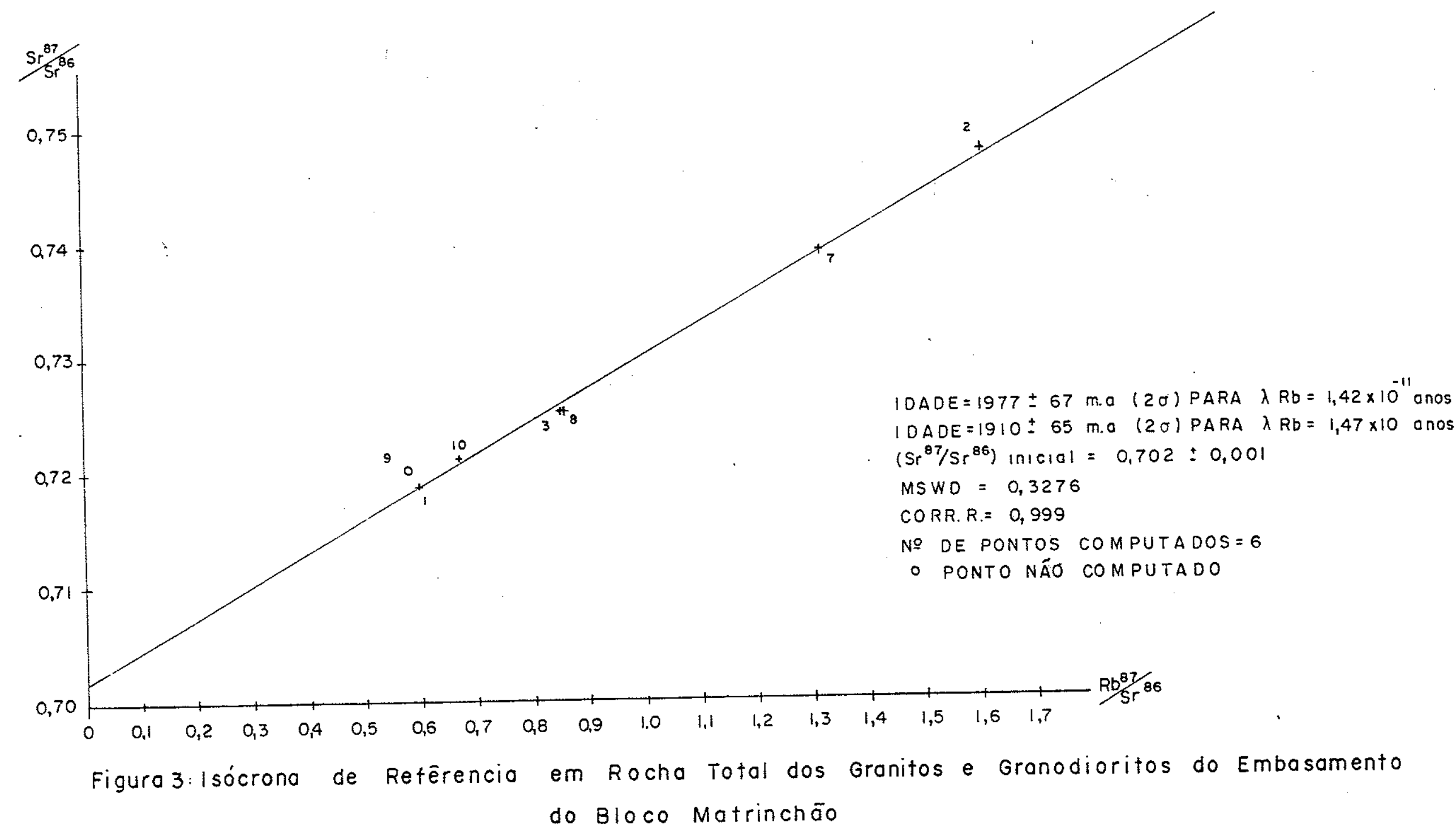


TABELA 1

DADOS ANALITICOS RD/SR DAS ROCHAS GRANITICAS E GRANODIORITICAS DO EMBASAMENTO

\begin{tabular}{|c|c|c|c|c|c|c|c|c|c|c|}
\hline $\begin{array}{l}\text { No de } \\
\text { Ordem }\end{array}$ & $\begin{array}{l}\text { Nọ de } \\
\text { Campo }\end{array}$ & Folha & Litologia & 10 Lab. & $R b(p p m)$ & $\operatorname{Sr}(p p m)$ & $\mathrm{Rb}^{87} / \mathrm{Sr}{ }^{86}$ & $s r^{87} s r^{86}$ & Idade & m.a. * \\
\hline 1 & $W I-J-43$ & $S C-21-V-C$ & Granodiorito & 2996 & 108,0 & 519,0 & 0,600 & 0,7188 & & \\
\hline 2 & $W I-J-44$ & $S C-21-V-C$ & Granito & 2997 & 125,0 & 225,0 & 1,610 & 0,7480 & 7850 & 130 \\
\hline 3 & $W I-J-53$ & $S C-2 T-V-C$ & Granito & 3346 & 139,0 & 476,0 & 0,850 & 0,7254 & 1680 & 190 \\
\hline 7 & $W I-J-64$ & $S C-21-V-D$ & Granito Porf. & 3347 & 135,0 & 296,0 & 1,320 & 0,7394 & 1810 & \pm 130 \\
\hline 8 & $W I-J-65$ & $S C-2 T-V-D$ & Granodiorito Porf. & 3349 & 138,0 & 467,0 & 0,860 & 0,7253 & 1650 & 190 \\
\hline 9 & $W I-J-66$ & $S C-2 T-V-D$ & Granodiorito Porf. & 3916 & 105,4 & 530,4 & 0,580 & 0,7202 & & - \\
\hline 10 & $W I-J-68$ & $S C-21-V-D$ & Granodiorito Porf. & 3344 & 106,2 & 467,5 & 0,670 & 0,7213 & 1700 & 200 \\
\hline
\end{tabular}


(WI-J-71), enquanto a inclinação da reta $\bar{e}$ devida aos pontos de nos 21 (Wi-J-81A) e $20(W I-J-81)$, que The conferem significativa precisão. 0 ponto analitico de amostra de no 19 (WI-J-80) não foi levado em conta, apesar de se situar mais prōximo que os demais em relação ao ponto de origem das coordenadas no diagrama, devido à sua posição nitidamente acima do traçado da isōcrona,fa to que pode ser interpretado, como devido a razãoinicial $\mathrm{Sr}^{87} / \mathrm{Sr}^{86}$ mais elevada da rocha em questão, ou ainda de se tratar de uma amostra mais antiga que o conjunto analisado.

De acordo com as interpretações de dados geocronotōgicos efetuados por Cordani et al (1979) e Tassinari (1981:) as rochas metamörficas supra mencionadas, que se situam no bloco Aripuanã pertencem à infraestrutura da faixa mōvel Juruena- Rio Nëgro. Ainda segundo os mesmos autores, a idade em torno de 1760 m.a., representa a principal fase de metamorfismo regional.

As anälises K-Ar em amostras de gnaisses do mesmo bloco tectónico, cujos dados analiticos podem ser vistos na Tabela 3, mostram valores mīnimos relativamente aos episödios de sua formação. A amostra de no 12 (WI-J-70) é um biotita gnaisse, no qual foi datada a biotita, que acusou $1373 \pm 34 \mathrm{~m} . \mathrm{a}$. e na 24 (PT-04A) cujos dados foram extraídos do trabalho de Tassinari et al (1978) foi datado o anfibōlio de melanossoma de migmati to que indicou $1369 \mathrm{m.a}$. Embora as idades determinadas apresen tem boa concordāncia, foram efetuadas em minerais com temperaturas cräticas de retenção de argōnio diferente. 0 exame da descri ção petrográfica da amostra de nọ 24 (PT-04A) mostra que esta apresenta parte do anfibólio de origem secundāria (uralita), desenvolvido as expensas de piroxēnio, bem como apresenta altera cão por intemperismo (argilo-minerais), fatores que permitem supor, que a rocha sofreu perda parcial de argōnio, estando portanto com a idade rebaixada. A amostra de no 12 (WI-J-70) não apresenta restrições quanto ä interpretação da idade, sendo considerada indicativa do resfriamento regional. 


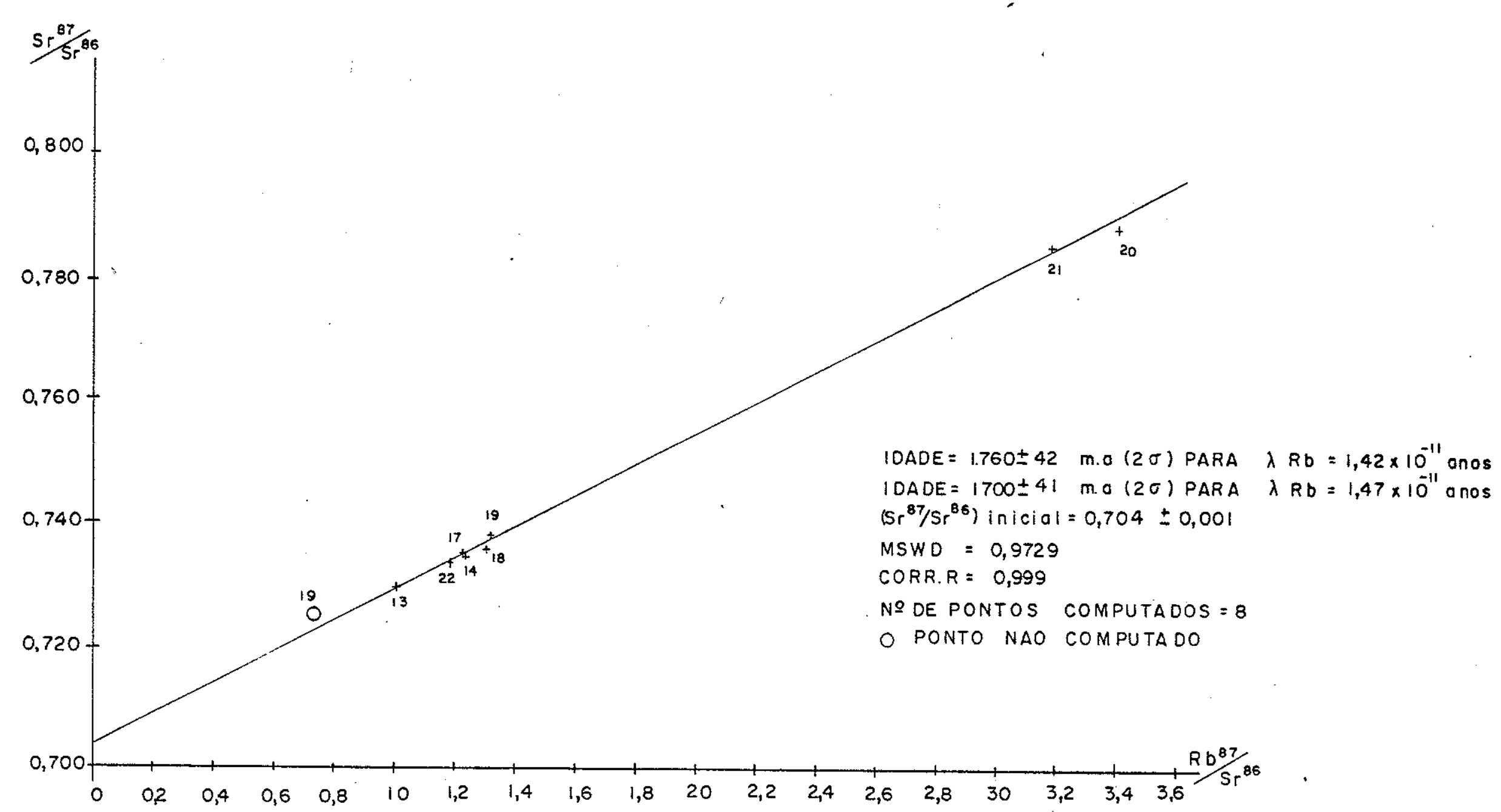

Figura 4: Isócrona de Referêncio em Rocha Total dos Gnasses do Embasamento do Bloco Aripuaná 


\section{TABELA 2}

DADOS ANALITICOS Rb/Sr DAS ROCHAS GNAISSICAS DO EMBASAMENTO

\begin{tabular}{|c|c|c|c|c|c|c|c|c|c|c|c|}
\hline $\begin{array}{l}9 \text { de } \\
\text { rdem }\end{array}$ & $\begin{array}{l}\text { No de } \\
\text { Campo }\end{array}$ & Folha & Litologia & NO Lab.. & $\mathrm{Rb}(\mathrm{ppm})$ & $S r(p p m)$ & $\mathrm{Rb}^{87} / \mathrm{Sr} \mathrm{r}^{86}$ & $s r^{87} / s r^{86}$ & Idade & m.a &.$\star$ \\
\hline $11 * *$ & PT-07 & $S C-2 T-V-D$ & Gnaisse & & 151,7 & 232,5 & 1,987 & 0,7499 & 1650 & \pm & 130 \\
\hline 13 & $W I-j-7]$ & $S C-2 T-V-D$ & $\begin{array}{l}\text { Muscovita } \\
\text { gnaisse }\end{array}$ & 3545 & 132,1 & 372,9 & 1,030 & 0,7296 & 1670 & \pm & 150 \\
\hline 14 & $W I-J-73$ & $S C-2 T-V-D$ & $\begin{array}{l}\text { Muscovita } \\
\text { gnaisse }\end{array}$ & 3446 & 134,8 & 317,4 & 1,230 & 0,7346 & 1620 & \pm & 120 \\
\hline 15 & $W I-J-75$ & $S C-2 T-V-D$ & $\begin{array}{l}\text { Biotita } \\
\text { gnaisse }\end{array}$ & 3917 & 137,3 & 308,7 & 1,290 & 0,7382 & 1790 & \pm & 130 \\
\hline 17 & $W I-J-78$ & $S C-21-V-D$ & $\begin{array}{l}\text { augen-gnaisse } \\
\text { milonitico }\end{array}$ & 3747 & 110,1 & 262,0 & 1,220 & 0,7352 & 1730 & \pm & 130 \\
\hline 18 & $W I-J-79$ & $S C-21-V-D$ & $\begin{array}{l}\text { biotita gnaisse } \\
\text { cataclästico }\end{array}$ & 3548 & 163,5 & 365,2 & 1,300 & 0,7356 & 1640 & \pm & 120 \\
\hline 19 & $W I-J-80$ & $S C-21-V-D$ & $\begin{array}{l}\text { Gnaisse } \\
\text { Granodioritico }\end{array}$ & 3918 & 121,8 & 476,0 & 0,740 & 0,7242 & 1800 & \pm & 190 \\
\hline 20 & $W I-J-81$ & $S C-2 T-V-D$ & $\begin{array}{l}\text { Gnaisse Granitico } \\
\text { cataclasado }\end{array}$ & 3919 & 186,5 & 159,5 & 3,410 & 0,7883 & 1700 & \pm & 64 \\
\hline 27 & $W I-J-81 A$ & $S C-27-V-D$ & $\begin{array}{l}\text { Leuco gnaisse } \\
\text { granitico } \\
\text { cataclasado }\end{array}$ & 3920 & 155,8 & 142,7 & 3,180 & 0,7855 & 1759 & \pm & 67 \\
\hline 22 & $W I-J-82$ & $S C-2 T-V-D$ & Leuco gnaisse & 2927 & 140,9 & 345,6 & 7,180 & 0,7334 & 1670 & \pm & 140 \\
\hline
\end{tabular}




\section{TABELA 3}

DADOS ANALITICOS K-AR DE ROCHAS DO EMBASAMENTO

\begin{tabular}{|c|c|c|c|c|c|c|c|c|c|c|}
\hline $\begin{array}{l}\text { No de } \\
\text { Ordem }\end{array}$ & $\begin{array}{l}\text { Nọ de } \\
\text { Campo }\end{array}$ & Folha & Litologia & NO Lab. (SPK) & Material & $\% \mathrm{~K}$ & $\begin{array}{l}\mathrm{Ar}{ }^{40} \mathrm{rad} .10^{-4} \\
\therefore \operatorname{ccsTP} / 3\end{array}$ & $\% A r^{40} a t m$ & Idade & m. a. \\
\hline 12 & $W I-J-70$ & $S C-2 T-V-D$ & Biotita gnaisse & 3675 & Biotita & 7,723 & 6,171 & 0,76 & $1373=$ & 34 \\
\hline $24 *$ & PT-04A & $S C-21-V-D$ & $\begin{array}{l}\text { Migma ti to } \\
\text { melanossoma }\end{array}$ & 2977 & Anfibōlio & 1,158 & 0,9289 & 1,07 & 1369 & \pm 17 \\
\hline
\end{tabular}




\section{V.2. Grupo Uatumã}

\section{V.2.1. Generalidades}

As rochas vulcano-plutōnicas do Grupo Uatumã aflo ram na região em três faixas distintas que podem ser individualizadas temporal e espacialmente através das associações litolōgi cas presentes, relações de campo e idades radiomëtricas.

Assim, na região do Rio Juruena (bloco. Matrinchão)-as exposições de rochas vuicānicas aparecem numa fajxa orientada $E-W$, com cerca de $30 \mathrm{~km}$. de largura que ladeia o bordo sul da chapada do Cachimbo, a $\vec{i}$ constituida por sedimentos do Grupo Beneficente e com os quais se justapõem lateralmente pela faiha do Cachimbo. Essa faixa estende-se continuamente desde o 1imi te oriental da ārea atē o rio Moreru. Reaparecendo depois entre o rio Aripuanã e o alto rio (igarapē) Agua Branca e no baixo curso do ültimo prōximo à sua foz. Constituj-se predominantemente por riodacitos e secundariamente por riolitos, dacitos, ignimbritos e brechas vulcānicas.

Os granitos, que por vezes são subvulcānicos e associados as efusivas (Silva, Leal, et al., 1974) ocorrem sobretudo acompanhando-as paralelamente pelo sul. No geral estão profundamente erodidos. e raras vezes apresentam feições circulares ou elipticas reconheciveis em imagens de radar, consequentemente nem sempre identificados no mapa. São maiormente alcali granitos de tendēncia alasquītica de granulação fina ā mēdia, que exibem cores claras, variando de branco à rosa mëdio.

Na região das bacias do rio Acari e Urucu, Ino bloco tectónico Acari), as vulcānicas ocupam uma faixa de orienta ção N-S, que se estende alargando-se paulativamente desde o baixo rio Maracanã atē os confins setentrionais da ārea. Limita-se a oeste com o embasamento cristalino e a leste atraves da falha do Maracanã-Urucu, com Formação Prosperança e Grupo Beneficente. Litologicamente predominam nessa ārea riolitos, andesitos pōrfiros e latitos, normalmente afetadas por metamorfismo dinamotermal brando. As rochas graniticas nessa faixa aparecem representadas por corpos subvulcānicos associados às efusivas onde o tipo gra- 
nofïrico é comum, bem como por granitos alasquīticos intrusivos as vezes capeadas por rochas vulcánicas. Ambos os tipos as vezes aparecem afetados por brechação e greisenização tardi-subsequente, onde ao lado dos graisens tipicos, aparecem cornubianitos e peraciditos.

Ainda na mesma faixa, na região do rio Aripuanãna sua margem direita, onde aflui o rio Maracanã, assim como no extremo noroeste da ārea, afloram biotita granitos róseos, de granulação mëdia e grossa, intrusivos no embasamento, às vezes estanîferos, sem associação com rochas vulcānicas, correlacionados aqui aos granitos tipo Maloquinha de Silva et al (1975). Esses corpos graníticos aparecem pröximo ao cruzamento de grandes sistemas de falhas, como o do Maracanã-Urucu, que è o prolongamento SW do lineamento Tapajōs de Silva et al (op.cit.) e a faTha do Aripuanã de direção NW-SE ou entre falhas sub- paralelas como as de Samaūma e Buiuçu.

A ültima faixa ou ārea a considerar corresponde a parte interna domo do Sucunduri (bloco tectônico Juruena) onde melhor se expõem as rochas vulcānicas. Cumpre destacar,que essas rochas no bordo interno leste, se dispõem aparentemente na forma de arcos paralelos concēntricos, mostrando um zoneamento vertical e lateral de rochas vulcânicas efusivas, piroclásticas grossejras (brechas e aglomerados vulcānicos), tufos, ignimbritos e de sedimentos imaturos de origem vulcânica. Litologicamente as rochas vulcānicas ācidas e intermediārias estão representadas por riolitos, riodacitos, dacitos, andesitos na forma de derrames, stocks e possivelmente de diques, associando-se ainda, material piroclástico como lavas brechōides, brechas e aglomerados vulcânicos, tufos de cristais, ignimbritos (welded tufs) e produtos de seu retrabalhamento aquoso, como tufitos psamiticos e psefiticos. Localmente, os riolitos pōrfiros mostram fácies subvulcānicos, gradando para granitos pörfiros como se observa logo a jusante da cachoeira das Cinco Ilhas no alto rio Sucunduri.

Observa-se ainda, como caracteristica

peculiar nas vulcânicas do domo do sucunduri uma intensa atividade hidroterma pōs-magmática, atravēs da transformação autometamōrfica das 
rochas vulcānicas, expressa pela epidotização, propilitização e quartzitificação (silicificação). Esse metamorfismo hidrotermal a parece desde. 0 fácies de alta até o de baixa temperatura. As sim, a ação das soluções ācidas e hidrotermas junto aos pretéri tos aparelhos vulcānicos ou dutos, bem como ao longo de fraturas pröximas, provocou a formação de quartzitos secundārios na acepção de Kumpan (1974), ā partir de lavas, tufo-lavas, tufos e ignimbritos, atravēs da sua quartzitificação (silicificação) re cristalização e substituição seletiva dos minerais fêlsicos pri mários e dos opacos por pirita, calcopirita e hematita. Essas rochas aparecem na forma de promontōrios muito resistentes a eròsão.

Ocorrem ainda amplamente pela ārea manifesta ções hidrotermais tardias, na forma de veeiros de quartzo, da mais variada geometria e dimensão, às vezes com especularita e mais raramente com ouro. Localmente,observa-se fenōmenos metas somäticos, que afetaram rochas vulcānicas ācidas, expressos mormente pela albitização parcial dos feldspatos.

\section{V.2.2. Petrografia}

Nas descrições abaixo apresentadas, quando um determinado tipo litolögico é caracteristico ou exclusivo de uma dada faixa, o nome dessa faixa aparece posposto.

\section{Riolitos}

Estas rochas são representadas sobretudo por riolitos pörfiros, granofīricos e esferulīticos. São geralmente de coloração vermelho amarronzado a rōseo pálido, rōseo arro xeado, marrom-esverdeado e raramente bordó. Possuem textura pórfira, blastoporfirîtica, microgrāfica e mais raramente esferuīitica, a estrutura é fluidal e subordinadamente amigdalóide. o quartzo se apresenta com forma prismätica, subēdrica, arredon dada e quase sempre corroïo, raramente ocorre na forma de bipi rämide, poucas vezes forma fenocristais, mas é constante na matriz. 0 feldspato potässico pode ser microclīnio, ortocläsio, e 
mais raramente sanidina e aparece geralmente na forma de fenocris tais euēdricos, ou então corroĩdos, maclados, frequentemente argi lizados ou seritizados. 0 oligoclásio ou a albita em geral apare cem mal conformados, às vezes zonados e quase sempre em quantidades subordinadas e como regra alterados em zonas sericiticas, carbonāticas ou argilosas. Biotita e muscovita ocorrem em. lamelas euēdricas e normalmente alteradas. Como acessörios e minerais secundärios aparecem sericita, magnetita, clorita, carbonatos, leucoxênio, pistacita, limonita e argilo-minerais. A matriz em geral é cripto e microcristalina, constituida por massa fina quartzosa ou quartzo-feldspätica rica em sericita muito fina, limonita e carbonatos. Muitas vezes observa-se estrutura fluidal, e mais raramente massas de esferulitos e intercrescimentos gräficos entre o quartzo e o feidspato potássico.

\section{Riodacitos e Dacitos}

Estas rochas são em geral pörfiras de cor cinza esverdeada com tons avermelhados e mais raramente de cor vermelha, marrom avermelhado, nas quais se destacam fenocristais ou fragmen tos de plagịocläsio (oligoclāsio ou andesina) às vezes albitiza dos, quartzo e feldspato alcalino (ortoclasio ou microclinio). os fenocristais de plagiocläsio podem ser euëdricos, subēdricos e anëdricos, às vezes zonados e comumente alterados em sericita,clo rita e carbonatos. 0 microclīnio é fortemente pertitizado, de geminação fina, tambēm frequentemente alterado e ocupado por sericita, carbonatos e argilo-minerais. 0 quartzo como fenocristal $\bar{e}$ menos frequente que o plagiocläsio ou ocorre em quantidade subordinada, tem formas subëdricas ou arredondadas e bordas com corrosão magmātica, por vezes restringe-se a matriz. A matriz é geral mente microgranular quartzo-feldspätica, tendendo a formar corpos micro e criptopegmatiticos. Mais raramente criptocristalina em vias de desvitrificação.

\section{Quartzitos Secundärios (domo do Sucunduri)}

Estas rochas geralmente apresentam cor róseo arro xeada a vermelho alaranjado, granulação finissima à fina, às ve- 
zes levemente orientadas, por concentração de poros, molides de sulfetos, fraturas e lentes finas alongadas paralelas de cor cin za, de material piroclástico. A textura é afañ̄tica ou piroclástica, enquanto a estrutura ē maciça ou orientada. A massa princi pal é constituída de quartzo, sericita fina e por pigmentos vermelhos de hematita fina. A composição dessas rochas é inconstante, apresentando as seguintes variações: quartzo $50-80 \%$, sericita 28 $-45 \%$, feldspato $0-2 \%$ e opacos de $1-5 \%$.

\section{Tufos Liticos (domo do Sucunduri)}

São rochas de cor parda alaranjada ou cinza, com manchas irregulares de tons laranja, cinza ou branco, de granula ção fina e estrutura maciça. Ao microscópioseus constituintes principais são os feldspatos, sobretudo plagiocläsio e quartzo em fragmentos algo arredondados. A matriz $\bar{e}$ fina, constituida de quartzo, possivelmente criptopegmatitica e agregados sericiticos muito finos acompanhados de pigmentos ferruginosos.

\section{Ignimbritos (domo do Sucunduri)}

Normalmente são de cor roxa ou avermelhada, afan̄iticos ou de granulação fina quando silicificados, com estrutura maciça e orientada. Ao microscōpio sua textura é vitrociāstica (pirociāstica) com inūmeros fragmentos de vidro (glass shards) normalmente desvitrificados envolvidos por massa de sericita e quartzo secundärio, e poeira ferruginosa finissima. Aparecem ain da como constituintes minoritärios em fragmentos grosseiros feldspatos e quartzo.

\section{Latitos (rio Acari)}

Este tipo de rocha apresenta estrutura maciça, en quanto a textura pode ser pörfira ou porfiritica com matriz afanïtica ou fanerítica fina à mëdia com fenocristais de feldspato. Exibe geralmente cor cinza pardacenta ou cinza avermethado. Ao 
microscōpio os fenocristais são constituĩdos por grãos quebrados e arredondados de plagioclāsio, por grãos idiomörficos de feldspato alcalino, ambos em geral sericitizados e epidotizados, e que podem alcançar 4.0-5,0 $\mathrm{mm}$ e mais raramente 2,0-3,0 cm, e subordinadamente por cristais bipiramidados de quartzo, normalmente arredondados e deformados, e ainda por biotita (parda). A matriz pode ser confusa, quartzo-feldspätica e zeolitica com tex tura fluidal, ou quartzo-feldspätica lineada por agulhas de arfvedsonita,junto à qual aparecem biotitas pardas, ou ainda consti tūida por manchas irregulares de intercrescimentos finissimos de quartzo. Dentre os värios tipos descritos, destacam-se arfvedsoni ta-quartzo latito, quartzo latito. e latito pórfiro.

Albita-Microclinnio Granicos (Alcali Granitos, rio Juruena)

Constituem o tipo petrogräfico que ocorre na região de Capivara no rio Juruena. Apresenta amplas variações quan to ā granulometria desde micro, fina atē grossa, suas cores va riam de cinza claro à rosa. Em lâminas delgadas, apresenta albita idiomörfica que forma fenocristais, que às vezes alcançam até $5 \mathrm{~mm}$, que por vezes aparecem com bordas irregulares e frequentemente encontram-se sericitizados. 0 microclinio ocorre em massa granular fina junto com o quartzo irregular e biotita que apresenta normalmente inclusões de titanita. Como minerais acessō rios apresenta biotita, titanita, apatita, opacos e como secundá rios epidoto, sericita e clorita, que formam aglomerações e saussuritizações. A textura varia de granular hipidiomōrfica à porfiritica.

\section{Granito Porfiritico (rio Juruena)}

E outro tipo assomante na região do rio Juruena, que em amostras de mão é porfiritico, Teucocrático, isōtropo com a matriz fanerītica de granulação fina a média, cuja cor dominan te é cinza mēdio. Em lāminas delgadas apresenta o plagiociásio normalmente na forma de fenocristais retangulares e zonados, que às vezes fazem parte da massa fundamental holocristalina consti- 
tūida por quartzo, microcī̄nio, biotita (pardo esverdeada), hornblenda (verde azulada claro) e muscovita. Como acessōrios e secundārios aparecem titanita, apatita, zircão, magnetita, epídoto e sericita. A textura é hipidiomörfica porfirîtica.

\section{Biotita Granito (rio Arìpuanã)}

E a variedade comum na região do rio Aripuanã, apresenta-se em amostras de mão com cores rosa claro e rosa escuro, fanerītico, inequigranular, de granulação mëdia à grossa e isótropo, leucocrática. Ao microscōpio seu principal constituinte $\bar{e}$ o microciinio, que ocorre em cristais xenomorfos de dimensões milimētricas e comumentemente pertītico. 0 quartzo se apresenta em grãos xenomorfos equigranulares e frequentemente com extinção ondulante. 0 plagioclāsio $\bar{e}$ albita-oligoclāsio que aparece em proporção subordinada e frequentemente com nūcleos saussuritizados. Por vezes, aparecem inclusões de fluorita nos feldspatos na forma de pequenas massas de ate $0,1 \mathrm{~mm}$. A biotita ocorre como constituinte menor em relação aos demais. Como acessōrios e: minerais secundärios aparecem apatita, zircäo, leucoxēnio e opacos.

\section{Granito Alasquītico (rio Acari)}

Em amostras de mão, este tipo è fanerītico e equi granular, de granulação mëdia que varia de 0,5 à $2,0 \mathrm{~mm}$., isótro po, hololeucocrätico, de cor rosa a rosa claro. Em läminas delga das exibe o microcīinio euëdrico, pertītico, maclado segundo lei da Albita, Periclinio, Carlsbad e Baveno, por vezes substitue o plagioclāsio. 0 plagioclāsio aparece em cristais subēdricos, gemi nados polissinteticamente por vezes corroīdos, frequentemente saussuritizados e sempre com dimensão média inferior à do microclīnio. 0 quartzo pode ser euēdrico, 1 impido e sem extinção ondu lante ou anēdrico com extinção ondulante e formar intercrescimen tos com o microclínio. A biotita é rara, ocorre em pequenos cris tais normalmente alterados em argilo-minerais e óxido de ferro. parecem ainda raros opacos e esfeno. A textura é granular hipi diomörfica. 
Granöfiro (rio Acari)

Macroscopicamente esta variedade de granito ē fanerītica de granulação fina, isōtropa, de cor vermelho rōsea, com alguns cristais maiores de quartzo xenomorfo, placas de mus covita e microclinio. Em läminas, exibe fenocristais independentes, de granulação mëdia de quartzo e microclinio imersos em matriz constituida por abundantes intercrescimentos granofïricos (microgräficos) de quartzo e microclīnio, esse ūltimo em parte substituído por albita-oligociásio. A muscovita é aparentemente primāria e encontra-se espalhada, e mais raramente aglomerada. como acessōrios apresenta opacos e zircão.

Greisen (Topāzio-Quartzo Greisen; rio Acari)

Este tipo de rocha desenvolve-se sobre tufos, riolitos pörfiros, granöfiros e granitos alasquīticos mormente em zonas de brechação. Em amostras de mão é compacto, isōtropo, com granulação que varia de grossa ä fina, sendo composto essen cialmente de quartzo, de cor cinza amarelada à cinza avermelhada, por vezes cravejada de numerosos pontos com reflexos metáli cos de pirita. Em seções delgadas, apresenta o seus principais constituintes, o quartzo e o topäzio normalmente anēdricos (este ütimo às vezes tende à idiomorfismo), que formam um agregado pavimentoso à engrenado. Como acessörios apresenta normalmente muscovita ou mica branca (possivelmente litinifera,zinnwaldita), rutilo, fluorita, zircão, plagiocläsio, pirita, cassiterita,molibdenita e magnetita. As micas ocorrem na forma de palhetas es parsas ou constituem agregados. O rutilo e acicular e aparece como inclusão no quartzo. A fluorita é roxa, preenche cavidades e exibe mujto bem suas clivagens octaēdricas. 0 zircão em geral constitui pequenos cristais euēdricos. A molibdenita é lamelar, e ocorre esparsa. 0 plagjoclásio (albita?) quando presente forma pequenos cristais bem geminados. A pirita aparece dispersa sendo constante em todas amostras. 


\section{Peraciditos (rio Acari)}

Megascopicamente essas rochas são compactas isōtro pas, de cor cinza röseo a vermelho, com manchas de tons mais cla ros, normalmente amarelados, de granulação mëdia ā fina, com frequentes cavidades cübicas de atē $2,0 \mathrm{~mm}$., que por vezes aparecem com pontos de massa escura provenientes da a 1 teração da pirita. Por vezes ainda apresentam visīculas. Em läminas foram reconhecidos essencialmente dois tipos de peraciditos ambos com textura granular xenomörfica. 0 primeiro, apresenta um mosāico granular de quartzo e topäzio, de tamanho e forma muito variāieis, com bordas reèntrantes, por vezes intercrescidas com pelīculas de ōxido de ferro, que limitam o contato dos grãos. Em quantidade subordinada apresenta palhetas pouco desenvolvidas de muscovita, por vezes reunidas em pequenos aglomerados ao lado da ilmenita e magnetita. o outro tipo $\bar{e}$ essencialmente constiturido de cristais xenomōrfi cos de quartzo, que apresenta abundantes e diminutas jnclusões, principalmente de plagiociásio, zircão e carbonatos, e como acessōrios exibe opacos (molibdenita e pirita).

\section{V.2.3. Geocronologia}

Conforme exposto acima as rochas do Grupo Uatumã foram divididas em três grupos de acordo com sua localização geogräfica, sendo que cada um desses grupos individualiza-se perfeitamente do ponto de vista petrográfico atravēs de seus produtos vulcānicos e plutōnicos, bem como geocronologicamente como se verä abaìxo.

Com as amostras de rochas vulcānicas do rio Juruena, foi construido um diagrama isocrōnico de referência de cinco pontos em rocha total, que aparece na figura 5 e cujos dados anaTiticos localizam-se na Tabela 4, sendo obtida idade de $1688 \pm 23$

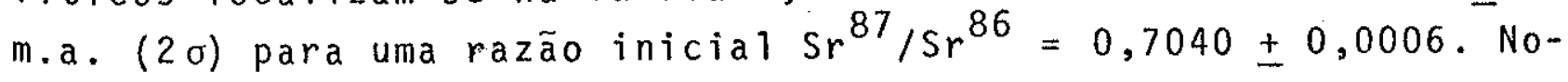
ta-se,que os pontos analiticos computados no cálculo de idade, apresentam um bom alinhamento e distribuição em relação à reta iso crônica. 


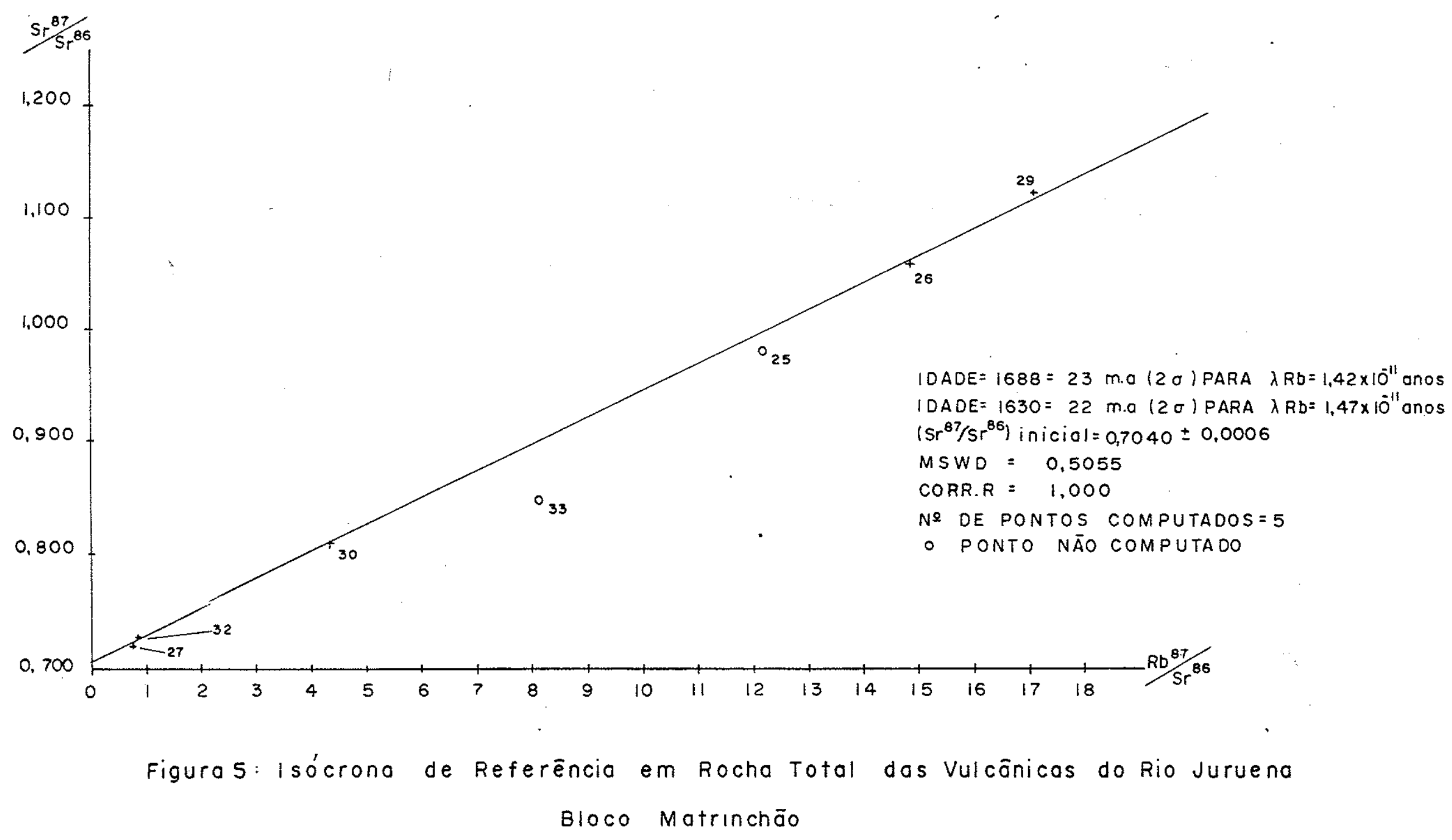


TABELA 4

DADOS ANALITICOS RB/SR DAS ROCHAS YULCANICAS DO RIO JURUENA

\begin{tabular}{|c|c|c|c|c|c|c|c|c|c|c|}
\hline $\begin{array}{l}\text { No de } \\
\text { Ordem }\end{array}$ & $\begin{array}{l}\text { No de } \\
\text { Campo }\end{array}$ & Folha & Litologia & Nọ Lab. & $R b(p p m)$ & $\operatorname{Sr}(p p m)$ & $\mathrm{Rb}^{87} / \mathrm{Sr}^{86}$ & $s r^{87} / s r^{86}$ & Idade & m.a.* \\
\hline $25^{\star \star \prime}$ & PT-21AA & $S C-27-V-D$ & Riolito & 630 & 159,5 & 19,7 & 12,19 & 0,9810 & 1550 & $\pm \quad 39$ \\
\hline $26^{* *}$ & PT-21AB & $S C-27-V-D$ & Riolito & 631 & 156,5 & 31,2 & 14,89 & 1,059 & 1656 & 46 \\
\hline $27 * \star$ & PT-59 & $S C-27-V-C$ & Riodacito & 2987 & 141,7 & 527,9 & 0,7800 & 0,7224 & 1560 & \pm 190 \\
\hline 29 & $W I-J-01$ & $S C-2]-V-C$ & Riolito & 3379 & $13.9,0$ & 24,4 & 17,14 & 1,123 & 1658 & 48 \\
\hline 30 & $W I-J-21$ & $S C-2 T-V-C$ & Riodacito & 2995 & 165,0 & 111,0 & 4,350 & 0,8090 & 1666 & \\
\hline $32^{\circ}$ & $W I-J-60$ & $S C-21-V-D$ & Dacito pörfiro & 3542 & 128,5 & 441,0 & 0,8400 & 0,7256 & 1700 & $\pm 190^{\circ}$ \\
\hline 33 & WI-J-62 & $S C-21-V-D$ & Riolito & 3348 & 170,0 & 67,0 & 8,780 & 0,8462 & 1165 & \\
\hline
\end{tabular}

* $\left(5 r^{87} / \mathrm{sr}^{86}\right)$ inicial $=0,705$

** Tassinari et al (1978) 
se situa bem abaixo da isōcrona, e que apresentou idade convencio nal de $1165 \pm 37 \mathrm{~m} . \mathrm{a}$, ē considerada com representante de uma mani festação vulcānica mais nova, pois que em secção delgada não apre senta nenhuma transformação secundāria, que pudesse causar rebaixamento de idade atravēs da saīda de Sr radiogênico do sistema.

0 outro ponto analitico que apresenta idade in ferior e anōmalo a esse conjunto vulcânico,corresponde a amostra de nọ 25 (PT-21AA) extrā̄do do trabalho de Basei (1977), com ida de $\mathrm{Rb} / \mathrm{Sr}$ convencional de $1550 \pm 39 \mathrm{~m} . \mathrm{a}$.. Verifica-se na descrição petrogräfica apresentada, que a amostra está recristalizada e alterada, fatos que devem ter propiciado a abertura do sistema e escape dosr radiogênico e consequentemente provocado rebaixamento da idade.

os dados analiticos de sete amostras "constitui das por albitamicroclinio granitos (alcali granitos) e granitos porfirīticos (Tabela 5) de uma ärea relativamente restrita em re1 ação à ponta da Capivara no rio Juruena foram tratados atravēs de diagrama isocrōnico em rocha total (Figura 6 ), sendo obtida a idade de $1676 \pm 19 \mathrm{m.a}$. (20) para uma razāo inicial de $0,7052 \pm$ 0,0004 . O diagrama apresenta os pontos analïticos extremamente bem alinhados e distribuĩdos, possibilitando um bom controle da razão inicial e atravēs das amostras com alta relação $\mathrm{Sr}^{87} / \mathrm{Sr}^{86}$, uma boá precisão quanto a idade. A sua variação média quadrātica ponderada (MSWD) de 0,1433 , considerada baixa, indica alto grau de colinearidade das amostras na isōcrona. A ünica amostra plotada,mas que não integra a isōcrona è a de nọ 34 (WI-J-0), cujo ponto analitico coloca-se um pouco abaixo ao seu traçado. A rejeição desse ponto, deve-se à considerāvel estágio de alteração deutérica expressa pela epidotização.

Tendo em vista que não havia dados anteriores para a região da bacia do rio Acari, (bioco tectōnico Acari), foram escolhidas adequadamente três amostras: 69 (YRA-774), 55 (M-336)e 68 (YRA-12) para determinações pelo mëtodo Rb/Sr em rocha total. A isōcrona obtida (Figura 7 ), embora com apenas três pontos ana $\bar{I}$ ticos (Tabela 6), mostra que eles apresencam adequada dispersão no diagrama, o que permite sugerir a idade obtida de $1675 \pm 12 \mathrm{~m} . \mathrm{a}$. $(2 \sigma)$ como ēpoca da formação dessas vulcānicas. A brecha latītica 


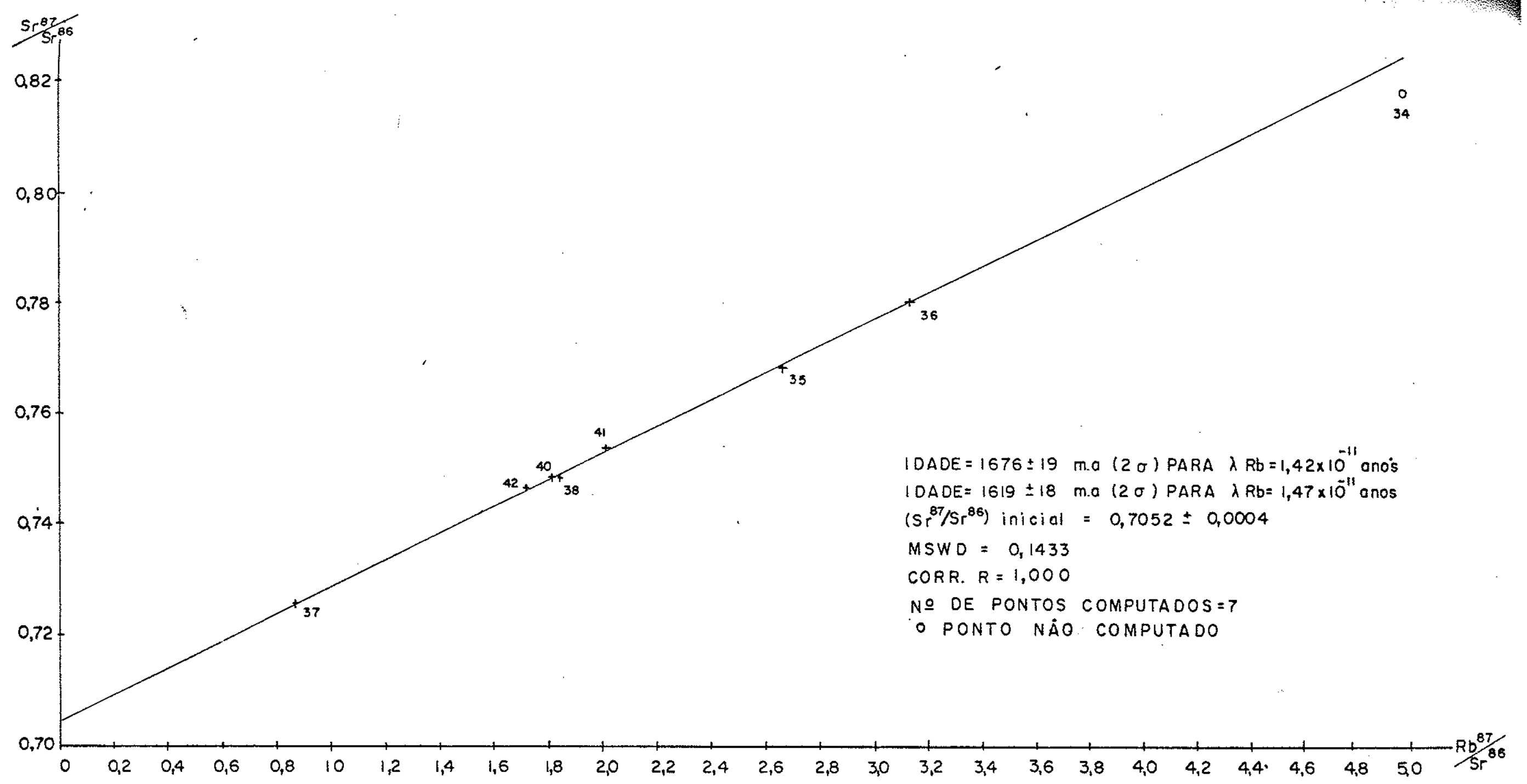

Figura 6: Isócrona de Referência em Granitos da Regiāo de Capivara, Rio Juruena, Bloco Matrinchão. 
TABELA 5

DADOS ANALITICOS RB/SR DE GRANITOS DO RIO JURUENA

\begin{tabular}{|c|c|c|c|c|c|c|c|c|c|c|}
\hline $\begin{array}{l}\text { Nọ de } \\
\text { Ordem }\end{array}$ & $\begin{array}{l}\text { Nọ de } \\
\text { Campo }\end{array}$ & Folha & Litologia & No Lab. & $R b(p p m)$ & $S r(p p m)$ & $\mathrm{RB}^{87} / \mathrm{Sr}^{86}$ & $S r^{87} / S r^{86}$ & Idade & $\mathrm{m} . \mathrm{a}$. \\
\hline 34 & $W I-3-0$ & $S C-27-V-C$ & Alcali granito & 4130 & 183,4 & 109,8 & 4,890 & 0,8185 & $1617 \pm$ & \pm \\
\hline 35 & $W I-J-12$ & $S C-21-V-C$ & Alcali granito & 2993 & 192,7 & 192,7 & 2,650 & 0,7684 & $1666 \pm$ & \pm \\
\hline 36 & $W I-J-15$ & $S C-21-V-C$ & Alcali granito & 2994 & 170,0 & 159,0 & 3,120 & 0,7807 & $1690=$ & \pm \\
\hline 37 & $W I-J-40$ & $S C-2 T-V-C$ & Granito & 3538 & 108,7 & 364,8 & 0,860 & 0,7258 & 1620 & 17 \\
\hline 38 & $W I-J-41$ & $S C-27-V-C$ & Alcali granito & 3539 & 138,5 & 220,0 & 1,830 & 0,7488 & 1668 & \pm \\
\hline 40 & $W I-J-48$ & $S C-27-V-C$ & Granito & 3000 & 177,0 & 285,0 & 1,800 & 0,7487 & $1684=$ & \pm \\
\hline 41 & $W I-J-49$ & $S C-27-V-C$ & Granito & 3001 & 178,0 & 258,0 & 2,010 & 0,7540 & 1698 & \pm \\
\hline 42 & $W I-J=50$ & $S C-21-V-C$ & Granito & 3345 & 185,0 & 315,0 & 1,710 & 0,7469 & 1708 & \pm \\
\hline
\end{tabular}

* $\left(s r^{87} / s r^{86}\right)$ inicial $=0,705$ 
amostra de nọ 69 (YRA-774) controla a razão inicial $\mathrm{Sr}^{87} / \mathrm{Sr}^{86}=$ $=0,7080 \mathrm{da}$ isōcrona, por outro lado, a amostra do riōijto pörfi ro nọ $55(M-336)$ controla a inclinação da reta, outorgando- The significativa precisão.

Os dados anal̄ticos dos granitos greisenizados a mostras de nọs $46(p-3703)$ e 47 (p-4385), tambēm foram plotadas no mesmo diagrama com fito de cotejo, e se colocaram abaixo da isocrona, bem como, apresentaram idades Rb/Sr convencionais respectivamente de $1503 \pm 35 \mathrm{~m} . \mathrm{a}$. e $1608 \pm 47 \mathrm{~m}$.a. inferiores as das vulcānicas nas quais se intrudem. Embora essas idades represèntam corretamente a sucessão dos eventos magmáticos, como ates tam os dados de campo,na opinião do autor devem estar rejuvenescidas diferencialmente, pelo processo de greisenização tardi subsequente, que provocou profundas transformações metassomäticas tanto no granito em questão (recristalização,neoformação de mine rais), como nas rochas vulcānicas encaixantes, pelo desenvolvimen to de expressivos corpos de greisens, peraciditos e cornubiani tos.

Foram analisadas ainda 6 amostras de rochas vulcano-plutônicas do domo do Sucunduri, cujos resultados foram interpretados em diagrama isocrōnico junto com 2 datações extra $\vec{i}$ das do trabalho de Tassinari et al, (1978) amostras de nos.: 43, 65 (Tabela 7). A isōcrona de referência obtida apresentou idade de $1641 \pm 14 \mathrm{~m} . \mathrm{a} .(2 \sigma)$ e razão inicial de $0,7080 \pm 0,1335$. A ida de ē praticamente a mesma do vulcano-plutonismo Teles pires anteriormente obtida por Basei (1977), fato que permite apoiar a idēia,que ambas as āreas tenham passado pelo mesmo episödio vulcānico. Na Figura 8 observa-se essa isōcrona, que apresenta bom $\underline{a}$ 7 inhamento de 6 pontos analiticos, constituidos exclusivamente de rochas vuicānicas. Enquanto que, os pontos de nos 43 (M-05), $48(S-682)$ representados por granitos, estão colocados abaixo da reta isocrônica, bem como apresentam idades convencionais infe riores à das vulcānjicas, respectivamente $1586 \pm 50 \mathrm{~m} . \mathrm{a}$. e $1624 \pm$ $48 \mathrm{m.a} . ;$ de sorte que esses dados permitem considerā-los como posteriores ao paroxismo vulcãnico da ārea. 


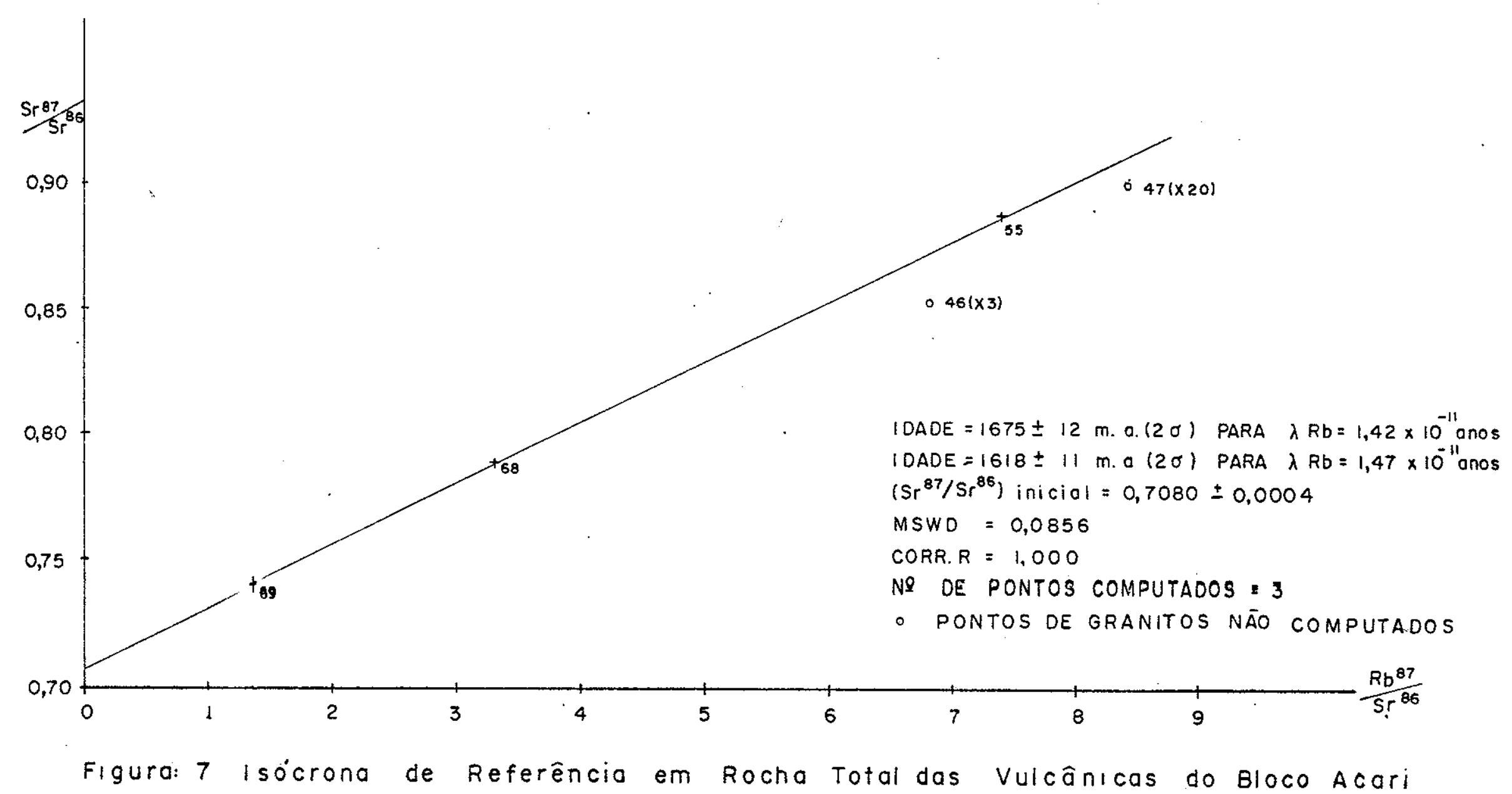




\section{TABELA 6}

DADOS ANALITICOS RB/SR DAS ROCHAS GRANITICAS E VULCANICAS DA BACIA DO RIO ACARI (BLOCO ACARI)

\begin{tabular}{|c|c|c|c|c|c|c|c|c|c|c|}
\hline$Q$ de Ordem & No de Campo & Folha & Litologia & Nọ de tab. & $\mathrm{Rb}(\mathrm{ppm})$ & $S r(p p m)$ & $\mathrm{Rb}^{87} / \mathrm{Sr}^{86}$ & $s r^{87} / s r^{86}$ & Idade & m. a \\
\hline 46 & $P-3703$ & $S B-27-Y-A$ & Granito & 3971 & 493,4 & 11,7 & 168,4 & 4,596 & 1608 & \pm 4 \\
\hline 47 & $P-4385$ & $S B-21-Y-A$ & Granito & 3912 & 228,3 & 33,6 & 20,49 & 1,147 & 1503 & \pm 3 \\
\hline 55 & $M-336$ & $S C-21-V-A$ & Riolito Pörfiro & 3439 & 158,6 & 63,3 & 7,38 & 0,8852 & 1700 & \pm 5 \\
\hline 68 & YRA- 12 & $S B-2 I-Y-A$ & Dacito Pörfiro & 3913 & 202,3 & 178,1 & 3,314 & 0,7884 & 1751 & \pm 6 \\
\hline 69 & YRA- 774 & $S B-2]-Y-C$ & Brecha Latîtica & 3437 & 157,6 & 335,3 & 1,36 & 0,7407 & 1820 & \pm 1 \\
\hline
\end{tabular}

$\left(s r^{87} / s r^{86}\right)$ inicial $=0,705$ 


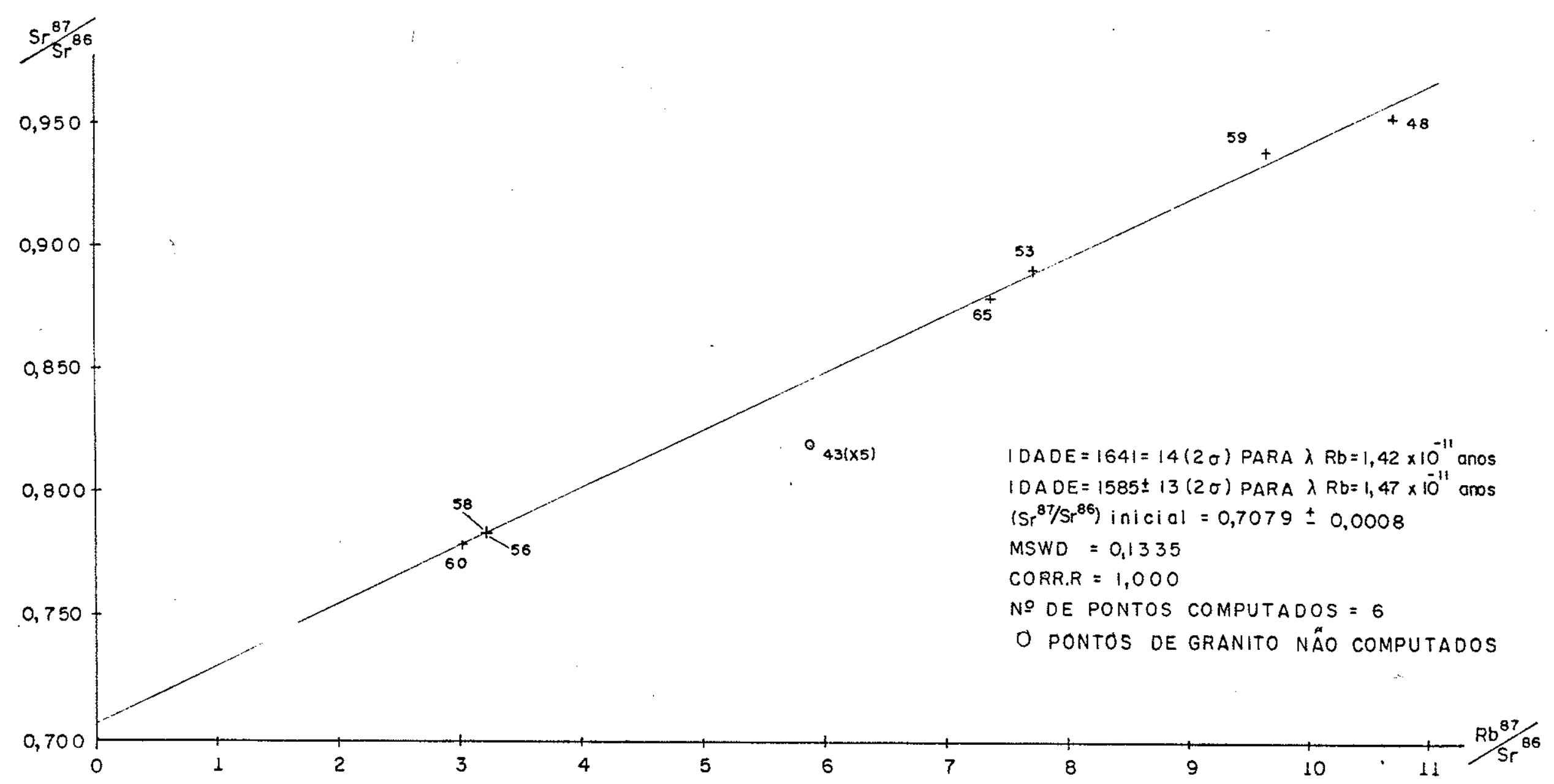

Figura 8: Isócrona de Referēncia em Rocha Total das Vulcânıcas do Domo do Sucunduri 
TABELA 7

DADOS ANALITICOS RD/SR DAS ROCHAS GRANITICAS E VULCANICAS DO DOOMO DO SUCUNDURI (BLOCO JURUENA)

\begin{tabular}{|c|c|c|c|c|c|c|c|c|c|}
\hline 9 de Ordem & NO de Campo & Folha & Litologia & NO Lab. & $\mathrm{Rb}(p p m)$ & $S r(p p m)$ & $\mathrm{Rb}^{87} / \mathrm{Sr}^{87}$ & $s r^{87} / s r^{86}$ & Idade $\mathrm{m}$. \\
\hline $43 * \star *$ & $M-05$ & $S C-21-V-A$ & Granito & 259 & $289 ; 6$ & 35,1 & $\cdot 25,24$ & 1,280 & $1586 \pm$ \\
\hline 48 & $S-682^{\prime}$ & $S C-2 T-V-A$ & $\begin{array}{l}\text { Granito } \\
\text { Porfiro }\end{array}$ & 3436 & 200,7 & 55,5 & 10,72 & 0,9552 & $1624 \pm$ \\
\hline 53 & $k-1359 /$ & $S C-2 T-V-C$ & Riolito Pörfiro & 3458 & 149,7 & 57,2 & 7,71 & 0,8909 & $.1678 \pm$ \\
\hline $56 \star \star$ & $\mathrm{PT}-04 \mathrm{~A}$ & $S C-21-Y-A$ & Dacito. & 642 & 204,4 & 177,9 & 3,350 & 0,7844 & $1640 \pm 1$ \\
\hline 58 & $s-642$ & $S C-21-V-A$ & Brecha Andesitica & 3434 & 121,6 & 110,6 & 3,21 & 0,7840 & $1715 \pm$ \\
\hline 59 & $S-683$ & $S C-21-V-A$ & Brecha Riolitica & 3432 & 152,0 & 46,7 & 9,63 & 0,9339 & $1654 \pm$ \\
\hline 60 & $5-692$ & $S C-2 T-V-A$ & Riolito & 3433 & 123,4 & 119,0 & 3,02 & 0,7783 & $1688 \pm$ \\
\hline $65 * *$ & $W-251$ & $S C-21-V-A$ & Riolito & 1254 & 227,4 & 91,4 & 7,326 & 0,8792 & $1655 \pm$ \\
\hline
\end{tabular}

$\left(s r^{87} / s r^{86}\right)$ inicial $=0,705$

- Basei (1977)

**Tassinari et al (1978) 


\section{V.3. Grupo Beneficente}

\section{V.3.1. Generalidades}

os sedimentos do Grupo Beneficente sobrepõem- se estratigraficamente por não conformidade as rochas vulcano-plutōnicas do Grupo Uatumã, sendo por sua vez recobertos por sequéncias sedimentares mais novas como a Formação Prosperança e Forma ção Bararati, e cortados pelas rochas alcalinas da Suite Intrusiva Cinco Ilhas. Compreendem sedimentos continentais e marinhos epicontinentais (praiais,distais e de talude) que de acordo com os modelos tectó nicos de sedimentação apresentados em Petri (1975), teriam sido depositados em ambiente de plataforma estāvel. Os primeiros constituem a base da sequéncia sedimentar, sendo representados por blocos e seixos de vulcânicas mormente de hialodacitos, no geral intemperizados, que alcançam até 80 metros de espessura, de acordo com as descrições do furo estratigräfico 1-B0-01 -AM, apresentadas em Moura (1980). A sequência marinha caracteriza-se por vários ciclos sedimentares aparentemente assimétricos, representados por camadas clásticas finas de arenitos ortoquartzíticos, arcōseos, subgrauvacas, grauvacas, protoquartzitos, siltitos, foThelhos e de calcārios dolomîticos organögenos com estruturas algais (estramotoliticas), bem como por calcārios bioclásticos, como brechas intraformacionais, dolarenitos, dolosiltitos e dololuti tos. Aparecem ainda no primeiro estrato de pelitos do primeiro ci clo, sedimentos manganesíferos e ferriferos (itabiritos). Assina1 am-se tambēm, ocorrências de fosfatos de origem orgânica como colofana em argilitos de cor verde clara "verdetes", e material pos sivelmente de sua recristalização como apatita, wavellita e varis cita no cimento em alguns nīveis de arenitos ou na forma de nödulos,que chegam a ser centīmetros, encontradiços nos panelóes do rio São Tomē (Coutinho e Svisero, 1975). A espessura da sequéncia marinha do Grupo Beneficente é superior a 1.000 metros.

Excelentes exposições de arenito com estratifica ção cruzada, com nīveis de conglomerados, podem ser vistas, imediatamente a jusante e a direita da foz do rio

São joão da Barra (Matrinchão) no rio Juruena, no paredão do plano de falha que justapõe às rochas do Grupo Beneficente com as vulcānicas do 
Grupo Uatumä, enquanto que as melhores exposiçōes com marcas de onda aparecem nos siltitos,que afloram na margem esquerda, a montante da desembocadura do rio são Carlos.

Ocupa predominantemente a porção centro-norte e centro-leste da ärea onde se estende com direção SW-NE, limitando-se: a oeste e norte com as vulcānicas das bacias dos rios Acari e Urucu atravēs da falha Maracanã-Urucu, a sudoeste com a For mação Prosperança a qual se sotopõe, e a norte-nordeste com as rochas sedimentares da Formação Bararati. A partir das cabeceiras do rio Urucu envolve atravēs de um enorme arco as rochas vul cano-plutónicas da parte interna leste do domo do sucunduri atē o seu segmento sul, que se situa na altura dos nascentes do rio Sucunduri (igarapë do Taxe), onde se limita com o Grupo Uatumã a travës da falha do Cachimbo. A partir desses extremos estende-se com direção W-E atē os confins orientais da ärea.

A anālise morfológica do dobramento do Grupo Beneficente em termos regionais, mostra que este $\vec{e}$ descontínuo ou idiomörfico, sem linearidade, sendo provocado por soerguimentos isolados na forma de domos e braquianticlinais,e entre os quais desenvolvem-se sinclinais de fundo chatolcom camadas em posição horizontal).

\section{V.3.2. Petrografia}

Ortoquartzitos e Protoquartzitos

São em geral de cor branca ou creme, compactos ou bem estratificados, constituĩdos por grãos de quartzo,tamanho areia mëdia, fina ou grossa, geralmente contendo um pouco de matriz caolinitica.o cimento normalmente é sīica,mas localmente predominam öxidos de ferro e exemplos são conhecidos em que suI fetos (pirita e subordinadamente calcopirita) podem atingir ate $50 \%$ do volume da rocha. Ao microscoppio ainda é possivel constatar nos grãos feições superficiais indicativas de boa maturidade. com contatos tangenciados e flutuantes; atualmente devido à sili cificação, todos os espaços vazios foram preenchidos.Por vezes a barita é encontrada como cimento autigênico.fosfatos como wavellita,variscita e apatita ocorrem como nódulos,ou como cimento. A. presença comum de fragmentos de chert parece indicar a existēn - 
cia de calcārio na ärea-fonte ou de extensos falhamentos.

\section{Grauvacas e Arcōsios}

São arenitos geralmente coloridos em vārios tons de cinza, granulação variävel, mal classificados, imaturos mineralogicamente, mas nem tanto texturalmente. As reações diagenēti cas, e consequlentemente o grau relativo de diagênese, se fazem sentir em função da disponibilidade de componentes quĭmico-mineralögicos; assim, o estägio locomörfico e o inîcio do estägio fi lomōrfico de Dapples (1962) é facilmente atingido, caracterizando-se por coroas autigēnicas de quartzo, feldspato e o surgimento de sericita. São comuns localmente fragmentos de silexitos, quartzitos e por vezes de rochas vulcānicas ācidas. Por outro la do, quase todos os grãos de quartzo apresentam evidencias de for te estiramento, fenōmeno não observado no cimento, parecendo pois provir de zonas de grandes falhamentos. Acessōrios incluem sillimanita, andalusita, estaurolita, xenotimio e amianto, o que deixa a antever uma ärea-fonte complexa. Barita como mineral cimentante tambēm è comum.

\section{Dolomitos}

Sob esta designação genērica estão agrupadas rochas clasto-carbonatadas associadas à fäcies e biostromas algais; que variam de dololutitos e brechas sedimentares intraformacio nais grosseiras. Os termos mais comuns são os de granulação intermediāria, isto é, dolarenitos (001̄iticos). A cor em geral é cinza mēdio a escuro. o grau de diagēnese ê um tanto variāvel de ponto para ponto, podendo-se, por recristalização e silicificação, ocorrer a total obliteração das microtexturas sedimentares originais, como se pode observar nos oólitos, pisólitos, oncölitos, e em alguns fragmentos angulosos de rocha carbonätica. 0 grau de impureza tambēm è variāvel, mas é no geral grande, ocorrendo quartzo e feldspato detriticos ao lado de uma suite grande de acessōrios, incluindo zircão, turmalina, muscovita, sericita, chert, anatasio, colofana e possiveimente cassiterita. 0 cimento diagenético, alēm do carbonato, salienta-se pela presença comum de barita, silica, fluorita e suifetos de Cu e Fe. Das estruturas presentes chamam a atenção pelo seu significado as marcas de 
onda, estratificação cruzada, laminações algais, "microvulcões" de lama, bem como estruturas fósseis de algas, perfeitas, tendo sido identificados tentativamente värios gēneros pela equipe de geologia da Cia. Administradora Morro VermeTho, incluindo Colon nella (rifeano inferior a superior), Minjaria e Inzaria (rifeano superior).

\section{Siltitos e Ardósias}

São rochas de cor cinza-mëdio a escuro em geral, eventualmente carbonosas. Os siltitos possuem populações de a reia muito fina a fina e mineralogicamente são semeihantes as grauvacas e arcósios, podendo igualmente transicionar para rochas carbonosas. Comumente apresentam pintas de sulfetos e a ba ritização pode ser localmente importante. Recristalização $\bar{e}$ em geral intensa, observando-se abundante crescimento autigênico ao redor de grãos de quartzo, feldspato, turmalina etc. Por vezes, o feldspato se transforma em massas de sericita e argilominera 1. A estratificação é conferida por variação no tamanho de grão (acamadamento gradacional) e conteüdo de opacos ( óxido de ferro e suifetos).

0 grau mäximo de dìaēnese observado $\bar{e}$ fillo mōrfico de Dappjes (op:cit.), no limite com o. metamorfismo,tendo sido jā observada presença de clorita, zeólita e paragonita. Acessōrios comuns incluem turmalina verde e azul, zircão, anatā sio e leucoxēnio. Silicificação e baritização são comuns, e provavelmente devidos a falhamentos e percolação lateral.

Ainda,importante do ponto de vista petrogenético é o aspecto superficial das partīculas com diametro inferior $\bar{a} 0,15 \mathrm{~mm}$, que apresentam-se muito retrabalhadas, não condizendo com o processo de sedimentação aquoso-marinho. Evidenciando, que se estä em preșença de sedimentos possivelmente retrabalhados, provenientes de erosão e transporte eōlicos, fato também sugerido pela composição mineralógica (quartzo e feldspato) e o tamanho minnimo das partículas arredondadas $(0,04 \mathrm{~mm})$. Este fato, se confirmado, sugere um ambiente vizinho da bacia de sedimentação, de carāter continental, com clima ārido e quente.quạn 
to ao ambiente de deposição dos siltitos, não resta dūvida quanto à sua natureza marinha rasa, de tipo quase praial, como indicam as marcas de onda e a estratificação cruzada.

\section{Argilitos}

Rochas argilosas constituem provavelmente a menor porção em volume no Grupo Beneficente, a julgar pelos poucos afloramentos encontrados.

Como são as mais facilmente decompostas pelo intemperismo, $\bar{e}$ de se supor que sejam mais comuns que o observado atē agora. Em geral possuem cores avermelhadas e arroxeadas, conferidas pela laterização, que pode mascarar muitos aspectos originais. Observa-se ainda, a presença de argilitos muito carbonosos em nīveis pouco espessos.

\section{V.3.3. Geocronologia}

Värias amostras de rochas classificadas macroscopicamente como ardösias, provenientes de furos de sondagem (amostras de nos 73a, 73b, 73c, 73d e 82) foram analisados pelo método Rb/Sr em rocha total e cujos analiticos aparecem na Tabela 8. o diagrama isocrônico representado pela figura 9 mostra que não houve homogeneização isotōpica do $\mathrm{Sr}$ em termos de rocha total, em bora podendo ter ocorrido a nīvel de fração fina. Portanto, a isō crona de referência traçada de $1180 \mathrm{~m} . \mathrm{a}$., não deve refletir o evento de carāter provavelmente pelo menos anquimetamörfico de Har rasowitz (1927, In:Gary et al, 1973) que atingiram as rochas. De qualquer maneira a disposição dos pontos analiticos prenuncia uma razão inicial tão alta quanto $\mathrm{Sr}^{87} / \mathrm{Sr} \mathrm{r}^{86}=0,75$. A dispersão dos pontos, bem como a alta razão inicial, podem ser devidos a pre sença de componentes detriticos, oriundos de uma fonte de rochas muito antigas. Outrossim, foi datado pelo mëtodo K-Ar o argilito 76(MV-01) amostrado nas cercanias de Terra Preta, cujos dados analiticos aparecem na Tabela 9. A idade obtida acusou $1351 \pm 44$ m.a., que pode ser considerada como minnima, expressando a idade da diagênese do pelito ou a idade de fechamento do sistema, apōs 


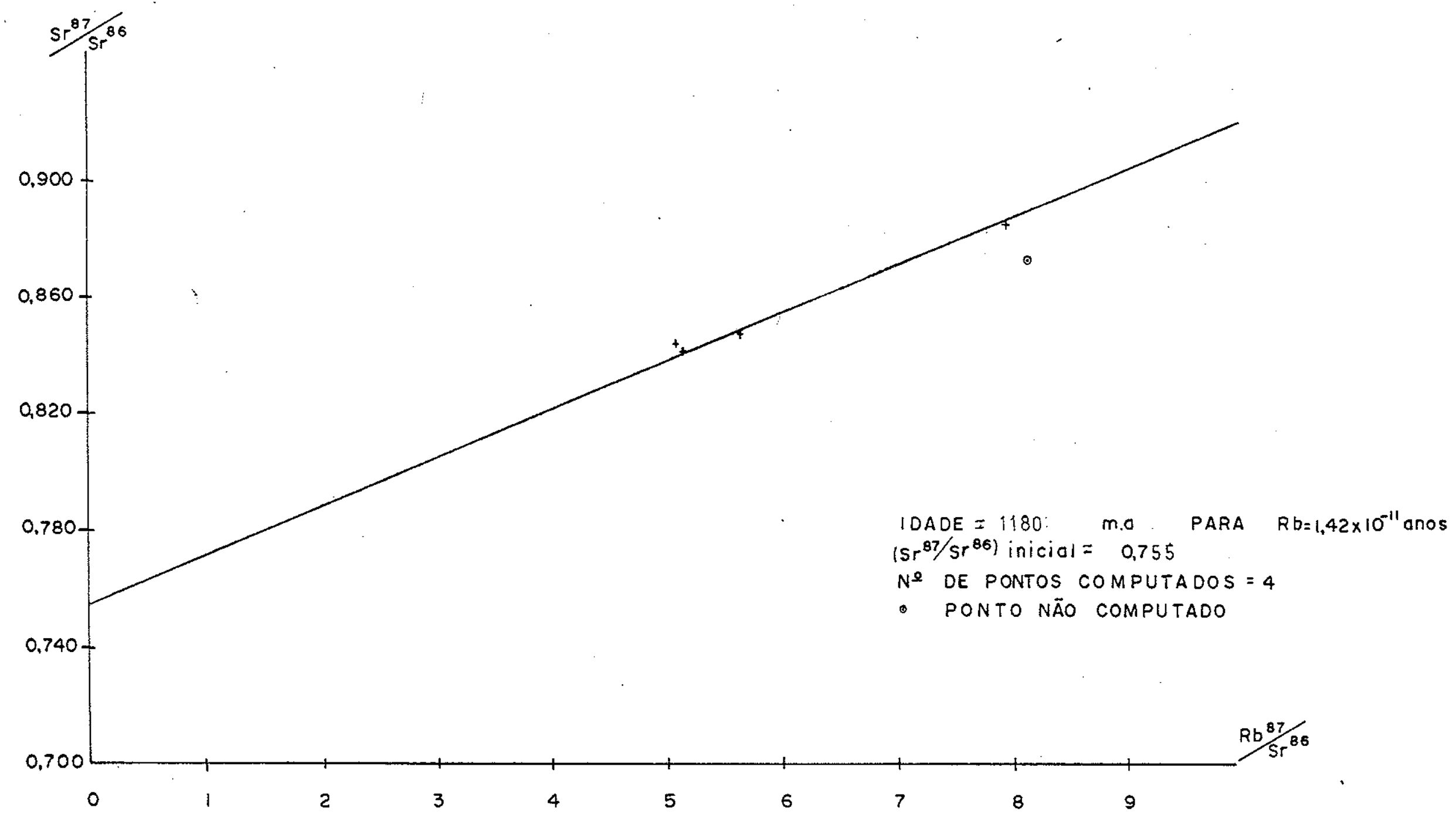

Figuro $9=1$ sócrona de Referēncia em Rocho Totol em Ardósıas do Grupo Beneficente 
TABELA 8

DADOS ANALITICOS RD/SR EM ROCHA TOTAL DE ARDOSIAS DO GRUPO BENEFICENTE

\begin{tabular}{|c|c|c|c|c|c|c|c|c|c|}
\hline 9 de Ordem & No de Campo & Folha & Litologia & $\begin{array}{l}\text { No L Lab. } \\
\text { SPR }\end{array}$ & $\mathrm{Rb}(p p m)$ & $\operatorname{sr}(p p m)$ & $\mathrm{Rb}^{87} / \mathrm{Sr}^{86}$ & $s r^{87} / s r^{86}$ & Idade $\mathrm{m}$. \\
\hline $73 \mathrm{~A}$ & PA3036A & $S B-2 T-Y-C$ & Argilito & 4852 & 171,8 & 99,1 & 5,08 & 0,8433 & 1762 \\
\hline $73 B$ & PA3036C & $S B-21-Y-C$ & Argilito & 4853 & 170,1 & 63,0 & 7,95 & 0,8848 & 1481 \\
\hline $73 C$ & PA3036F & $S B-21-Y-C$ & Argilito & 4854 & 159,5 & 83,0 & 5,64 & 0,8461 & 1623 \\
\hline 730 & PA3036H & $S B-21-Y-C$ & Argilito & 3855 & 245,0 & 89,3 & 8,07 & 0,8733 & 1364 \\
\hline 82 & $S-820 A$ & $S B-21-Y-C$ & Argilito & 4851 & 146,9 & 89,9 & 5,13 & 0,8403 & 1705 \\
\hline
\end{tabular}

TABELA 9

DADOS ANALITICOS K-AR EM ROCHA TOTAL DE PELITOS DO GRUPO BENEFICENTE

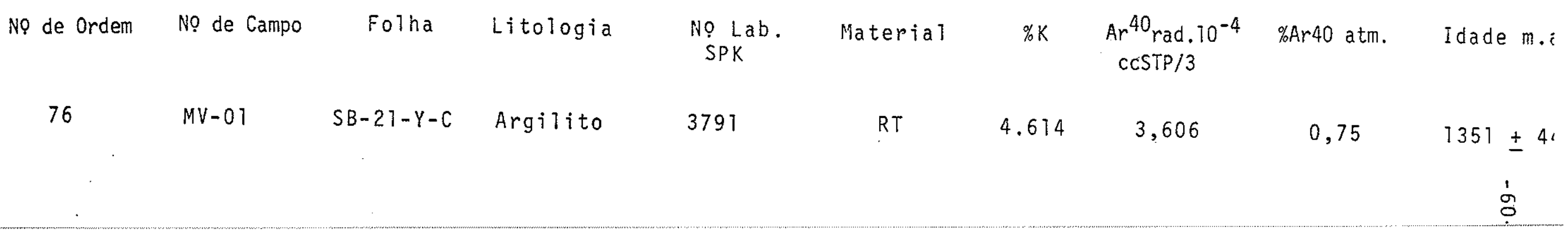


a intrusão do dique de latito que aflora nas proximidades. No entanto, näo pode ser exclü̈da a hipōtese de se tratar de uma idade mista, na qual uma parte do $A r^{40}$ radiogēnico provēm de mate rial detrítico como sugere Hurley (1959) e Hurley et al (1963).

0 posicionamento temporal do Grupo Beneficente $\bar{e}$ obtido indiretamente, pois este, se sobrepõe as vulcānicas āci das e intermediārias mais jovens do Grupo Vatumã e aos diques de rochas bäsicas que as cortam e acusam idades em torno $1640 \mathrm{~m} . \mathrm{a}$. , enquanto o limite superior ē devido tambëm a um dique de diabä sio que o secciona, e que acusa idade de $1493 \pm 22 \mathrm{~m}$. a.

\section{v.4. Suite intrusiva Cinco Il has}

\section{V.4.1. Generalidades}

A Suite Intrusiva Cinco IThas, que $\vec{e}$ aqui apresen tada informalmente, constitui um conjunto pluto-vulcānico alcalino que corta as rochas vulcano-plutōnicas do Grupo Uatumã na parte interna do domo do Sucunduri, e as sedimentares do Grupo Beneficente no mëdio rio São Tomë e que atë o momento não encon tra paralelo com nenhuma outra manifestação magmätica alcalina conhecida no segmento meridional da Plataforma Amazōnica pelo ca räter e idade do magmatismo.

Dentre os vārios corpos alcalinos na ärea do domo do Sucunduri, o denominado aqui de "Maciço Sienītico Cinco Ilhas"fica a alguns quilómetros a oeste da cachoeira das Cinco Ithas e coloca-se paralelamente ao curso geral do rio Sucunduri. Tem forma alongada com eixo maior orientado na direção NWN-SSE e cerca de 21 quilömetros de comprimento por 5 quilömetros de largura mäxima nas suas partes protuberantes.

Apresenta uma grande variedade de rochas alcali nas, entre as quais aparecem alguns tipos petrogräficos "sui generis" (egirina-nefelina sienitos "albiticos") peralcalinos, ricos ou por vezes constituídos exclusivamente por minerais sódicos como albita, nefelina, egirina, riebeckita, arfvedsonita,bar kevickita, e eudialita-eocolita, que segundo a classificação mi- 
neralögico modal de Johannsen (1938) e Sorensen (1974) seriam mariupolitos e litchfielditos, devido ã predomināncia da albita sobre o feldspato potässico, ou como ünico feldspato. Vale frisar ainda, que os dois tipos petrogräficos supraditos são caracterīsticos de rochas miasquiticas, enquanto que algumas dessas rochas do "Maciço Sienítico Cinco Ilhas" são em termos de composição minera $\not \partial g i c a$ tipicamente agpaĩticas. Deprende-se portanto, que as classificaçōes mineralōgico-modais não as tipificam adequadamente.

Aparentemente nas bordas esse maciço apresenta um zoneamento complexo da fenitização do exo para o endocontato do corpo, pela gradativa passagem de riōlitos para anfibólio-feldspa to-quartzo fenito (alcali granito), anfibōlio-piroxēnio-feldspato-quartzo fenito (alcaii sienito com quartzo), piroxênio-feldspa to fenito (alcali sienito). Os fenitos do endocontato, passam para egirina-nefelina sienitos "(mariupolitos e litchfielditos)" às vezes portadores de silicatos complexos de zircōnio como eudialita-eocolita. Entrementes, não pode ser abandonada a possibilidade que uma parte das rochas tomadas camo fenitos seja realmente intrusiva. Assinalam-se ainda na parte central do maciço, eudialita -pegmatitos grosseiros que cortam os egirina-nefelina sienitos.

Outro corpo denominado aqui de "Maciço Sienítico Maracanã, aflora à SW do "Maciço Sienitico Cinco Ilhas", nas nascentes do rio Maracanã. Sua forma è à grosso modo, circular, com cerca de $7 \mathrm{~km}$ de diāmetro. Foi reconhecido apenas no seu flanco leste onde foram amostrados egirina sienitos (alcali sienitos). A travēs de imagens Erts, foram reconhecidas mais duas estruturas mui to semelhantes às anteriores (CAMV, 1980), possiveimente tambëm constituĩdas por rochas alcalinas que ficam a $\mathrm{N}$ e SW do Maciço Si enitico Maracanã; o primeiro provavelmente, constitui o prolongamento setentrional do maciço Maracanã, do qual se separa pela fa Tha Cinco Ilhas, enquanto o segundo com dimensão aparentemente igual forma um corpo isolado.

As demais ocorrēncias constituem diques, pequenos derrames e possivelmente "plugs" e "necks", representados petro graficamente por fonólitos, microsienitos, traquitos, lusitanitos e latitos. Dentre essas rochas, os fonōitos são as mais abundantes. Cortam tanto as rochas vulcānicas como as alcalinas do "Maci 
-ço Sienitico Cinco Ilhas" e provavelmente as do Grupo Beneficente.

São dignos de nota os fonōlitos com disjunção colunar aflorantes entre a cachoeira dos Indios (Areia Branca), e a do Parasita (Saltos) no leito do paranã da margem direita do rio Sucunduri, onde formam um dique com mais de 25 metros de largura e extensão superior a 1,5 quilometros, controlado por estrutura disruptiva com direção $N 350$ W. No interfiūvio do paranã supra mencionado e o rio Sucunduri (na altura da cachoeira dos Indios) os traquitos aparecem no alto de uma crista que ladeia pe10 lado leste uma estrutura aparentemente circular depremida. Ao norte, cerca de 2,5 quilometros a montante da cachoeira da India aflora um dique de fonōlito encaixado em estrutura disruptiva de direção N 35-40ọ E, ao lado de um de microsienito. Além dessas, vale lembrar a ocorrência de um dique de.luzitanito,entre o rio Sucunduri e o Igarape do vermelho, a 2,5 quitōmetros a jusante da cachoeira do Arrependido.

Na região da Terra Preta, a norte do domo do Sucunduri, aparece um dique vertical de latito-lusitanito com dire ção N 450 e, 20 metros de espessura mēdia, e 4 à 5 quilōmetros de extensão e que corta os arenitos do Grupo Beneficente.

As rochas alcalinas do mëdio rio São Tomë, segundo os dados da Mineração Itaiba S/A (1977), que as denominou de Com plexo Alcalino de São Tomē, aqui rebatisadas de Maciço Alcálino Mundurucus, aparecem numa depressão topogräfica, que corresponde a uma estrutura braquianticlinal desventrada e muito erodida. 0 eixo major da depressão tem direção aproximada $N-S$, e mede cerca de $9,5 \mathrm{~km}$, enquanto o menor de direção $E-W$ apresenta em mëdia $2,5 \mathrm{~km}$.

Ainda segundo a mesma fonte, a estrutura. braquian ticlinal foi originada pela intrusão das rochas alcalinas que soergueram, arqueando os ortoquartzitos do Grupo Beneficente(nas bordas a estrutura apresenta mergulhos de 100) sem protrudi-1os, fato inferido pela ausēncia de juntas e diques radiais, bem como pela exposição descontinua das rochas alcalinas. 
Dentre os värios tipos petrogräficos de rochas al: calinas, cabe ressaltar os nefelina sienitos e quartzo bostonitos. o primeiro tipo apresenta nefelina euëdrica,cancrinita, feldspato alcalino, egirina, eudialita (?) e acīculas de rutilo. o segundo tipo apresenta quartzo, biotita, plagioclāsio, apatita,zircão (abundante), vênulas de carbonato e feixes de cristais de rutilo.

\section{V.4.2. Petrografia}

Dentre as inümeras variedades petrogräficas de rochas alcalinas plutōnicas da ärea destacam-se pulasquitos, "mariu politos", "litchfielditos", umptekitos, larvikitos e nordmarkitos, e entre as filonares e vulcānicas aparecem fonōlitos, traquitos, mi crosienitos, lusitanitos, latitos e bostonitos. A descrição dessas rochas, bem como de suas variedades aparecem no anexo, com os nümeros de ordem de 94 a 112 .

\section{V.4.3. Geocronologia}

Dentre as amostras coletadas de rochas alcalinas e intermediärias, 7 foram analisadas pelo método Rb/Sr e 3 pelo mëtodo K/Ar, todas em rocha total e cujos dados analiticos, apa recem nas Tabelas 10 e 11 , e os respectivos pontos da amostragem no mapa de idade radiométricas. Com as amostras que foram analisas pelo mëtodo $\mathrm{Rb} / \mathrm{Sr}$, foi elaborada uma isōcrona de referéncia de 4 pontos (Figura 10), que acusou $1447+15 \mathrm{~m} . \mathrm{a} \cdot(2 \sigma)$,para uma razão.inicial de $0,7051 \pm 0,0001$. O autor considera a idade obti da como indicativa da formação dessas rochas, visto que, ocorre uma boa distribuição e colinearidade dos pontos analiticos (nọs. 94, 110,111 e 105) ao longo da reta isocrōnica. 0 ponto nọ 110 (WI-S-132) controla a razão inicial da isōcrona, por outro lado o ponto nọ 105 (M-02) define a inclinação da reta, outorgando The significativa precisão, dado a sua posição muito afastada do ponto de origem do sistema de coordenadas $\mathrm{Rb}^{87} / \mathrm{Sr}^{86}-\mathrm{Sr}^{87} / \mathrm{Sr}{ }^{86}$.

Com relação às anālises $K / A r$, duas amostras de nọs.107 $(N-9699 A)$ e 111 (WI-S-418) mostraram valores inferiores aos ob tidas pelo método Rb/Sr convencional, enquanto que a terceira 109 


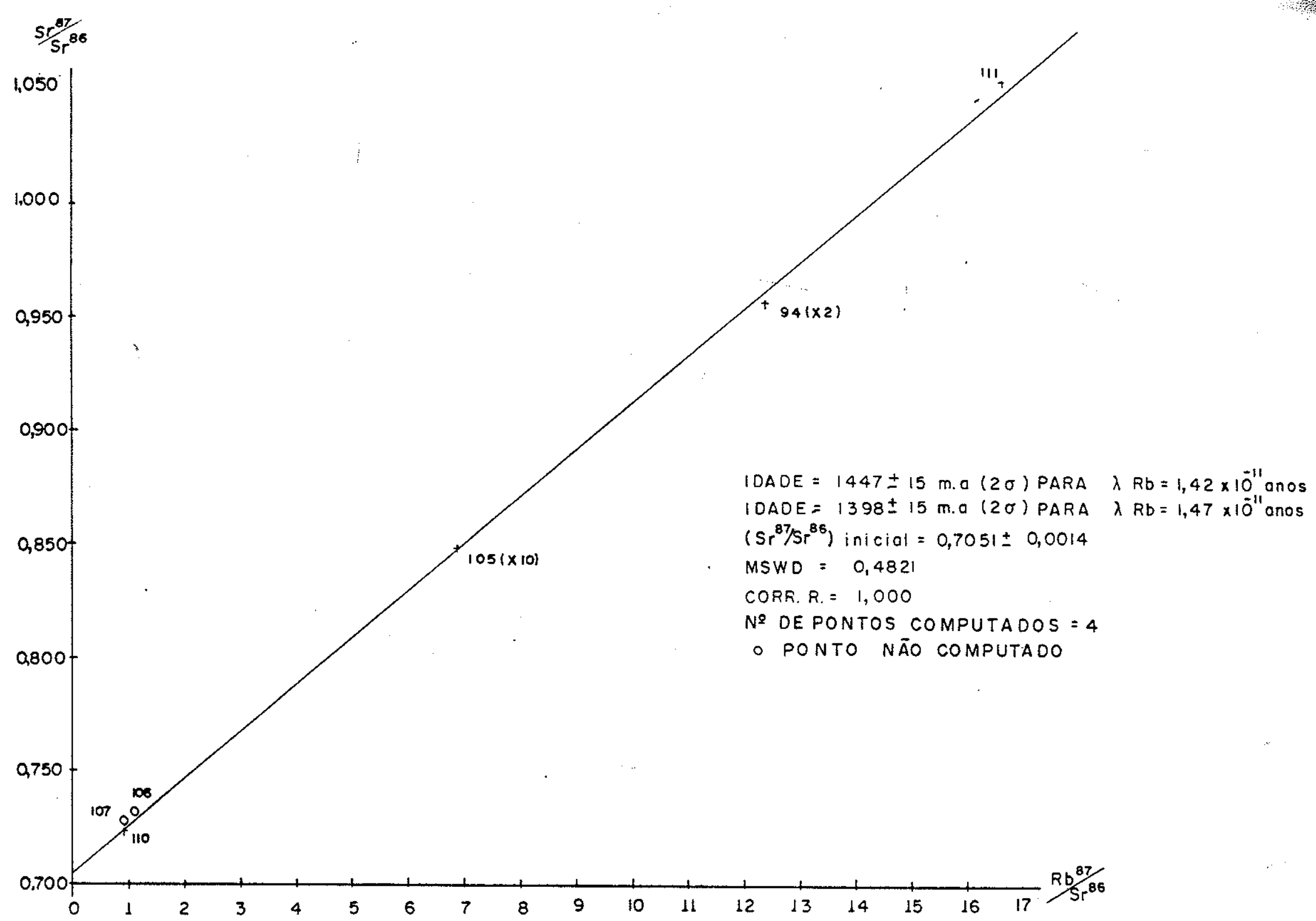

Figura 10: Isócrona de Referência em Rocha Total Para as Alcalinas do Domo do Sucunduri 
DADOS ANALITICOS Rb/SR DAS ROCHAS ALCALINAS DO DOMO DO SUCUNDURI

\begin{tabular}{|c|c|c|c|c|c|c|c|c|c|}
\hline$\because$ de Ordem & Nọ de Campo & Folha & Litologia & NO Lab. & $\mathrm{Rb}(\mathrm{ppm})$ & $S r(p p m)$ & $\mathrm{Rb}^{87} / \mathrm{S}^{86}$ & $s r^{87} / s r^{86}$ & Idade m.a.* \\
\hline 94 & $c-558$ & $S C-21-V-A$ & $\begin{array}{l}\text { egirina-nefelina } \\
\text { sienito }\end{array}$ & 3914 & 63,7 & 7,7 & 24,82 & 1,210 & $1417 \pm 39$ \\
\hline $105 * *$ & $M-02$ & $S C-2 T-V-A$ & $\begin{array}{l}\text { egirina-augita - } \\
\text { nefelinà-sienitn }\end{array}$ & 1089 & 178,2 & 8,4 & 69,22 & 2,138 & $1443 \pm 41$ \\
\hline 106 & $N-9699$ & $S B-21-V-A$ & Latito & 3440 & 80,0 & 209,4 & 1,110 & 0,7319 & $1690 \pm 150$ \\
\hline 107 & $N-9699 A$ & $S B-2 T-V-A$ & Latito & 4173 & 74,2 & 232,9 & 0,920 & 0,7274 & $1690 \pm 160$ \\
\hline 109 & $W I-S-729$ & $S C-21-V-A$ & Fonölito & 1265 & 271,5 & 10,5 & 85,74 & 2,180 & $1201 \pm 31$ \\
\hline 110 & WI-S- 132 & $S C-2 T-V-A$ & Microsienito & 2998 & . $\quad 39,2$ & 179,4 & 0,950 & 0,7247 & $1440 \pm 20$ \\
\hline 711 & $W I-S-418$ & $S C-27-V-A$ & Fonólito & 2999 & 216,0 & 38,8 & 16,66 & 1,055 & $1464 \pm 43$ \\
\hline
\end{tabular}

$*\left(s r^{87} / s r^{86}\right)$ inicial $=0,705$

** Tassinari et al (1980) 
TABELA 11

DADOS ANALITICOS K-AR DAS ROCHAS ALCALINAS DO DOMO DO SUCUNDURI

NQ de Ordem No de Campo

Folha Litologia No Lab.(SPK) Material

107

109

111

$\mathrm{N}-9696 \mathrm{~A}$

WI-S- 129

WI - S -418

$S B-2]-Y-C$

Latito

Fonöito

Fonotito
4220

3764

3674
$\% \mathrm{~K}$

RT

RT

RT
$\operatorname{Ar}^{40} \mathrm{rad} .10^{-4}$

$\% \mathrm{Ar}^{40} \mathrm{~atm}$.

1,817

4,641

2,743

2,417

1,756

1,568

0,54

Idade m.i

$\begin{array}{ll}2,16 & 800 \pm 1 \\ 1,15 & 1171 \pm \vdots \\ 0,54 & 1182 \pm \vdots\end{array}$


(WI-S-129) mostrou valor semelhante. Em todos os casos, resultados K/Ar dessas rochas a principio podem ser considerados como mini mos, pois apresentam ortociásio na sua composição,mineral que no geral exibe baixa retentividade de argōnio. O valor da idade K/Ar da amostra nọ:107 (N-9899A) que é de $800 \pm 18 \mathrm{~m} . \mathrm{a}$. não pode ser cote jado com as idades obtidas pelo método Rb/Sr convencional que se situam em torno de $1690 \pm 160 \mathrm{~m} . \mathrm{a}$., porque são pouco significativas, dado as baixas relaçós $s r^{87} / \mathrm{Sr} 86$, pröximas ä origem do siste ma de coordenadas $\mathrm{Rb}^{87} / \mathrm{Sr}^{86}-\mathrm{Sr}^{87} / \mathrm{Sr}^{86}$, ao grande erro na determinação das idades, bem como não condizem com a situação geológica. Ainda quanto às amostras nọs 109 (WI-S-129) e 111 (WI-S-418), a primèira apresentou a idade $K / A r$ com $1171 \pm 39$ m.a., um pouco infe rior, porēm ainda dentro do limite de erro experimental de determinação da idade pelo mëtodo Rb/Sr convencional, que acusou $1201 \pm$ 31 m.a., portanto a idade obtida pode ser considerada como indica tiva de sua formação. No que tange a segunda amostra, de nọ 111 (WI-S-418) cuja anāiise K/Ar indicou $1182 \pm 37 \mathrm{~m} . \mathrm{a}$. , enquanto a sua determinação pelo mëtodo $\mathrm{Rb} / \mathrm{Sr}$ convencional apresentou $1463 \pm$ $43 \mathrm{m.a.,}$ a diferença à menor da idade $\mathrm{K} / \mathrm{Ar}$ pode ser atribuída $\bar{a}$ perda de argōnio radiogēnico pelo ortoclāsio como explicado acima e à processos de alteração secundāria como zeolitização (desenvol vimento de natrolita e analcima).

\section{V.5. A Formação Prosperança}

\section{V.5.1. Genera 1 idades}

Aflora numa ampla faixa de direção SW-NE que recobre per discordäncia erosiva o Grupo Beneficente no bordo NW do domo do Sucunduri, estendendo-se desde o mëdio rio Maracanã (graben do Maracanã) até os manadouros do rio Urucu, limitando-se a oeste pela falha de Maracanä-Urucu, com rochas vulcānicas da bacia do rio Urucu e a leste com as do domo do sucunduri. A NE do domo, aflora na região do Paneiro, onde preenche um päleo-baixo. No extremo SW nas cabeceiras do igarapē Agua Branca aparentemente se assenta diretamente sobre embasamento cristalino onde consti tui chapadões, que se destacam claramente em imagens radar.Consiste de sedimentos de plataforma pouco ou não dobrados de arenitos lito-feldspäticos vermelhos finos a médios, às vezes conglomeräti cos, intercalados por siltitos e argilitos vermelhos que tem no 
mĩnimo 300 metros de espessura. Na base apresenta conglomerado po limitico com fragmentos de arenito,siltito, argilito, dolarenito, es tromatolitos silicificados, quartzo e rocha vulcānica de acordo. com as descrições encontradas em Moura (op.cit.).

\section{V.5.2. Petrografia}

Descrições petrogräficas de algumas litologias representativas de Formação Prosperança podem ser encontradas no Anexo I sob os nos. 135a, 135b, 135c, 135d e 135e.

\section{V.5.3. Id ade}

A idade da Formação Prosperança é determinada indi retamente. Assim,na parte interna do domo do Sucunduri,ela recobre a extremidade norte da Suite Intrusiva Cinco Ilhas com idade radiomētrica de $1450 \mathrm{~m} . \mathrm{a}$., e como no contato entre ambas, não hä evidëncias de metamorfismo termal (CAMV;1980), por conseguinte, considerase aqui esta idade como sendo o seu limite temporal inferior. Outros sim, na região da serra do Pajura, a oeste,fora,porém contịguamen te a ārea estudada a Formação Prosperança acha-se afetada pela intrusão das Alcalinas Guariba segundo Leal et al (1978), cujas idades radiometricas Rb/Sr convencionais situam-se entre 1100 e $1400 \mathrm{~m} . \mathrm{a}$. , sendo que seus dados analīticos não permitem elaboração de uma isōcrona. Esta variação de idades sugere que se trata de um maciço polifāsico, cuja primeira manifestação magmātica $\bar{e}$ aqui admitida como limite temporal superior da Formação Prosperan ça, embora com reservas.

\section{V.6. Formação Bararati}

\section{V.6.1. Generalidades}

Sobrepõe-se cobrindo parcialmente a formação anterior, em possīvel discordāncia paralela uma sequencia de conglome rados e arenitos horizontais, que aparecem constituindo "Inselbergs" (residuais) e mesas dissecadas, mormente pela margem esquerda do rio Bararati, logo apōs a inflexäo do seu curso geral N-S para NE, a qual ē aqui informalmente denominada de Formąção Bararati. A seção inferior é constituída por conglomerados que a- 
presentam seixos bem arredondados, predominantemente de metareni tos em matriz arenosa grosseira, e a superior por arenitos bem classificados de granulação tamanho areia com pouco cimento cau1inico.(CAMV, 1980).

\section{V.6.2. Idade}

Como a unidade repousa diretamente e em aparente discordancia paralela sobre o Grupo Beneficente e a Formação Pros perança, deve talvez representar uma cobertura sedimentar de ida de fanerozöica.

\section{V.7. Magmatismo Básico}

\section{V.7.1. Generalidades}

As rochas bāsicas aparecem amplamente distribuī das pela ärea, formam corpos discordantes que seccionam indistin tamente o embasamento cristalino, granitos e efusivas do Grupo Uatumã, sedimentares proterozöicas do Grupo Beneficente e da For mação Prosperança, e provavelmente as rochas sedimentares mais jovens representadas pela Formação Bararati.

Dentre os principais, tipos petrogräficos na ärea em apreço, reconhecem-se basaltos, gabros, olivina gabros, diabá sios, olivina diabāsios, metadiabāsios e mugearitos, que aparecem frequentemente alterados deutericamente.Constituem stocks, às vezes estratificados como o Gabro Palhal, que aflora na baixa bacia do igarapé Paxiüba, afluente da margem esquerda do rio Aripuanã, fora dos 1 imites da ārea e diques que muitas vezes se estendem por mais de uma dezena de quilōmetros, ou formam uma sé rie de corpos alinhados descontīnuos na forma de cordão, dentre värios,vale citar os aflorantes na margem direita do alto rio São Tomé e mëdio rio Urucu, entre Jacaretinga e Espirito Santo. Em algumas localidades como na região do rio Acari e no alto rio Sucunduri aparecem corpos com características de efusivas, mas cu jas relações de campo são pouco elucidativas para defini-los decisivamente como derrames. Os corpos filonares apresentam um pro nunciado controle tectónico,alojando-se predominantemente em es- 
truturas disruptivas de direção NE-SW e secundariamente nas com direção NW-SE. Em algumas áreas como no bordo interno do domo do Sucunduri constituem enxames de diques subparalelos de direção NE-SW.

Nos locais onde atravessam rochas sedimentares, mor mente no interfiūvio igarapē Bararati e rio Juruena ostentam aspecto de cristas que são bastante pronunciadas em imagens radar.

\section{V.7.2. Petrografia}

As descrições petrogräficas das rochas bāsicas podem ser vistas no anexo, onde aparecem sequencialmente do nüme ro 113 ao 135 .

\section{V.7.3. Geocronologia}

Dispõe-se para a ārea de 11 determinações radiomë tricas K/Ar, das quais duas, as de nos 118 (PT-31-3A) e 119 (PT-75) foram extraídas do trabalho de Tassinari et al. (op.cit.) e cujos dados analiticos encontram-se na Tabela 12. Duas das amostras estudadas, não aparecem no mapa de idades radiomëtricas, a de no 115 (MV-06) que pertence ao Gabro Palhal e a de $n \varphi \quad 133$ (YRN-2329) amostrado logo ao norte da ärea estudada no rio Acari.

os dados analïticos obtidos são satisfatörios, apresentam em geral erros inferiores a, 3\%. Não havendo nenhuma amostra que apresente restrição interpretativa quanto aos dados analiticos em si.As idades variam num amplo intervalo de tempo, entre 1650 e $205 \mathrm{~m} . \mathrm{a}$.

No caso do magmatismo proterozōico mēdio a superior se dispõe de 8 idades, seis resultados constituem 3 conjun tos de idades cada um de dois membros: nọs 113 (L-1214) e 121 $(\mathrm{S}-753)(900 \mathrm{~m} . \mathrm{a}),. 116(\mathrm{NP}-36)$ e 131 (WI-S-493) (1270 m.a.), 132 (WI-S-511) e $133($ YRN-2329) (1650 m.a.), enquanto outros dois, nos 11.5 e 126 indicaram 1360 e $1490 \mathrm{~m}$.a. respectivamente. As idades 
em torno de 1650 e $1490 \mathrm{~m} . \mathrm{a} .$, são significativas no contexto geo 1ögico regional, pois a primeira corresponde a manifestação de magmātica bäsica pós Grupo Vatumä, que antecede a sedimentação do Grupo Beneficente, fato confirmado por observações de campo por Liberatore (1972) e pelos geölogos da Cia.Adm. Morro Vermelho, enquanto a segunda, corresponde a atividade eruptiva básica pōsGrupo Beneficente. A amostra de no 115 (MV-06) proveniente do Gabro Palhal indicou idade de $1360 \mathrm{~m}$.a., considerada aqui como mīnima, visto que a amostra estudada apresenta alteração hidro terma 1. As idades situadas entre 1240-1290 m.a. (amostras nos.116 e 131 ) são consideradas tambëm como significativas,uma vez que fòram encontrados valores semelhantes nas ärea contīgua a oeste, folhas SB-20 purus e SC-20 Porto Velho por Teixeira (1978).

Para a atividade īgnea básica mais nova do proterozöico superior, tem-se 2 determinações, ambas relacionadas a corpos encaixados na falha do Maracanã-Urucu. Seus resultados são praticamente iguais (não obstante a grande distāncia entre ambos) e concordantes com o padrão de idades obtido por Teixeira (op.cjt.)para a região sudoeste da Plataforma Amazōnica.

Estes fatos, na opinião do autor, são considerados como suficientes para tomar tais resultados como geologicamente significativos.os dois ültimos resultados, devem-se a focos de atividade mágmātica bāsica do paleozōico inferior e do triássico jurässico com 565 e $205 \mathrm{~m}$.a., sendo representados por diques de diabāsio, que cortam sedimentos do Grupo Beneficente e pös-Benefi cente, aflorantes respectivamente no rio Juruena, a montante da foz do rio São Tomē e na região do igarape Assunção,afluente. pela margem direita do rio Sucunduri a jusante da Terra Preta.

A idade da amostra de no 4 (WI-J-8a), referente a um corpo de gabro,que aflora no rio Juruena e que acusou $1070 \pm 13$ m.a., é considerada como minima, visto que esta rocha encontra - se bastante cataclasada e hidrotermalizada, consequentemente de ve ter perdido parte do argōnio radiogēnico.

Baseando-se nos dados geocronolōgicos, petrográfi cos e de campo, cada um dos focos de magmatismo bāsico foi con siderado como unidade estiratigräfica. 
TABELA 12

DADOS ANALITICOS K-AR DAS ROCHAS BASICAS

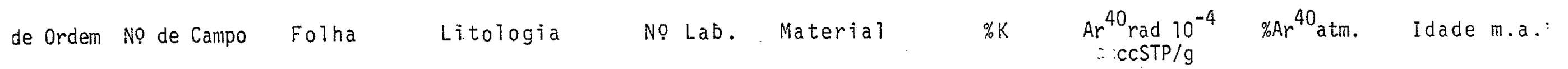

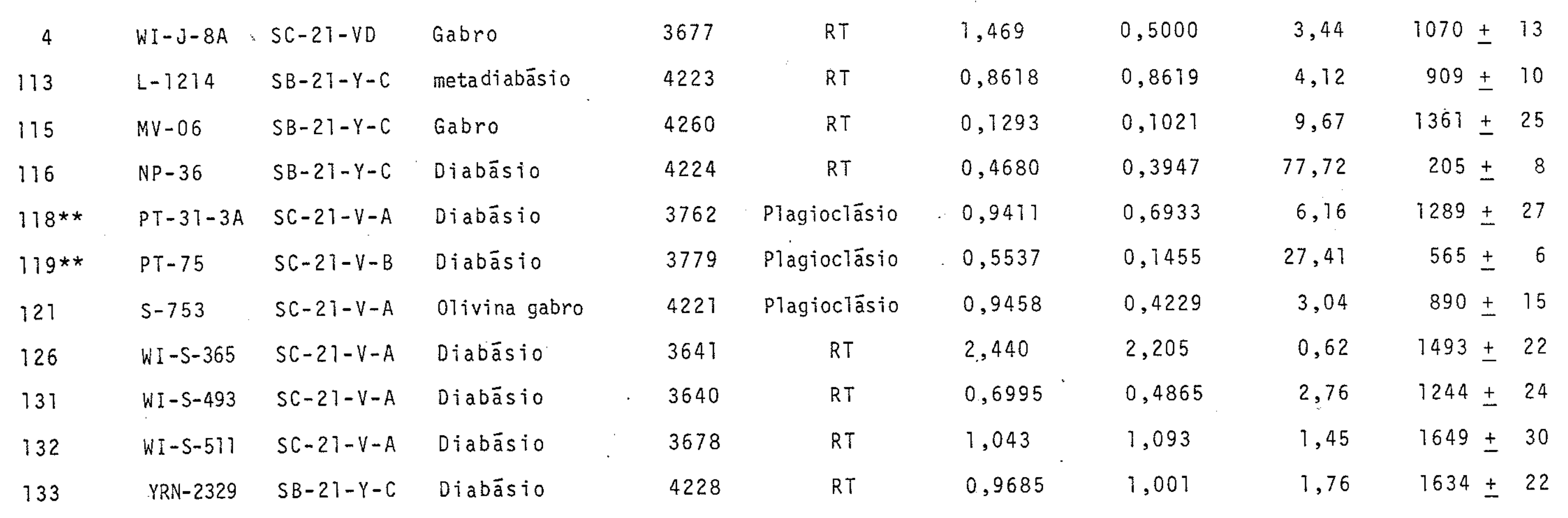

* $\left(s r^{87} / s r^{86}\right)$ inicial $=0,705$

** Tassinari et al (1978) 
Assim temos, o Diabäsio Andorinhàs com $1649 \pm 30 \mathrm{~m} . \mathrm{a}$. que aflora na forma de diques, a jusante da cachoeira das Andori nhas no rio Acarij; o Diabāsio Sucunduri com $1493 \pm 22$ m.a., que corta predominantemente as rochas vulcānicas no leito do rio Su cunduri, cerca de $5 \mathrm{~km}$ a jusante da cachoeira da Areia Branca; Diabásio Bacaba com $1289 \pm 27 \mathrm{~m} . \mathrm{a}$., que aflora cortando o Grupo Uatumã no igarapē Bacaba; Diabāsio Urucu com $909 \pm 10 \mathrm{~m} . \mathrm{a}$. , que aflora ao longo do rio Urucu, na forma de diques alinhados descontinuos, que se intrudem nas rochas vuicâniças do Grupo vatumä, o Diabásio Labiriñto com $565 \pm 6 \mathrm{~m} . \mathrm{a}$., que aflora na forma de dique cortando o Grupo Beneficente, a montante da cachoeira do Labirinto, no baixo rio Juruena, e o Diabāsio Assunção com $205 \pm$ $\pm 8 \mathrm{m.a}$., que corta na forma de diques o Grupo Beneficente pela margem direita do mëdio igarape Assunção. 
VI. COMPARTIMENTAÇAOO TECTÕNICA DA REGIAOO DO DOMO DO SUCUNDURI

VI.1. Generalidades

No aspecto tectónico pelo menos cinco grandes blocos de falha podem ser reconhecìdos na região. Tais blocos, de caräter bem extenso,tem características lito-estruturais e geomor folögicas diferentes, ressaltando-se a simples observação dos mosāicos de radar. São eles: bloco Camaiū, bloco Acari, bloco Aripuanã, bloco Matrinchão e bloco Juruena (Figura 11).

\section{VI.].J.. Bloco Camaiū}

o bloco Camaiū desenvolve-se na porção noroeste da região, estendendo-se sempre em declive para NE, indo perder- se sob sedimentos da Formação Barreiras jă nos mëdios e baixos cursos dos rios Canumã e Abacaxis, fora da ärea considerada. Este broco constitui-se dominantemente por sedimentos do Grupo Beneficente, onde às vezes aparecem restos de vulcānicas Uatumã, em outros locais, sobretudo a oeste, acha-se sotoposto a sedimentos mais recentes.

Delimita-se a SE por um conjunto de fa 1 hamentos normais de direção NE-SW, dos quais o mais importante $\bar{e}$ a falha preliminarmente denominada de Samaūma, que dobra e soergue as vulcānicas Uatumã no seu trecho SW.

A SW e W, tudo leva a crer, Timita-se por falha ao longo do rio Aripuanã (no mapa ela estä em posição apenas apro ximada), imensa sutura de crosta, extensão da falha de Aripuanã, de direção NW-SE, acompanhada desde o NW de Mato Grosso, onde foi identificada por Liberatore et a 1, (1972). Este falhamento teria colocado em contato lateral as litologias do Grupo Beneficente e Com plexo xingu,contato este obscurecido em grande parte pelas coberturas fracamente ou não dobradas da Formação Prosperança. A leste nordeste, o bloco recobre-se tambëm pela Formação Prosperança. 


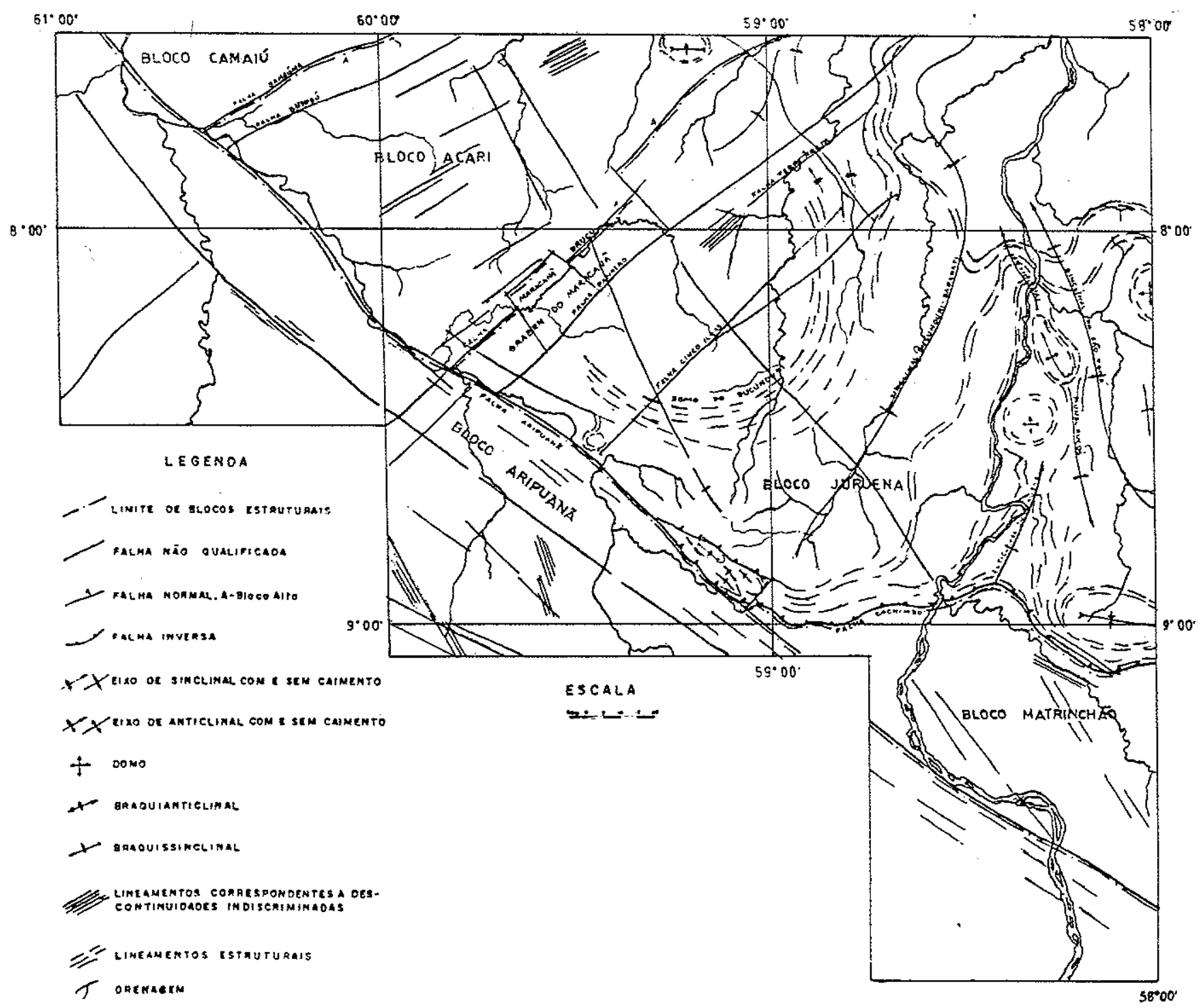

FIGURA :1: COMPARTIMENTAÇÄO TECTONNICA DA REGIÄO DO DOMO DO SUCUNDURI

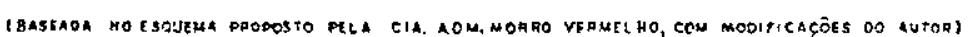




\section{VI.1.2. Bloco Acari}

o bloco Acari juntamente com o biloco Juruena é uma das feições tectōnicas mais evidentes da região. Desenvolvendo-se no sentido geral NE-SW, constitui-se dominantemente de rochas do Grupo Uatumã, e secundariamente pelo Complexo Xingu e pelo Grupo Beneficente. Seus 1 imites são dados por falhamentos extensos regionais, um pelo menos de dimensão continental (a jä citada faTha do Aripuanã).

A NW faz contato com o Grupo Beneficente atravēs dà falha Samaūma, de natureza rotacional normal, onde a porção SW elevou-se mais do que a extremidade NE do bloco. A SE limitase com o bloco juruena através da falha Maracanã-Urucu, pertencente ao lineamento Tapajōs, descrito por Santos et al. (op. cit.). Trata-se aqui tambēm de um falhamento normal, em que o lado NW subiu, mas a característica normal não é tão evidente. A SW este bloco faz limite com gigantesca sutura lou zona de sutura) de direção NW-SE, paralela a qual se alinha o rio Aripuanã. Finalmente a NE, uma sērie de falhas paralelas a do Aripuanã,mas menores, o cortam transversalmente.

São caracteristicas deste bloco,os. Tineamentos bastante conspīcuos nas vuicānicas, com direção NE-SW, alguns de les certamente devidos aos fraturamentos antes descritos, como os que aparecem junto à falha Samaüma. Ainda com relação aos fraturamentos, os mais antigos parecem ser os da direção NW, onde se encaixam diques bäsicos de idade proterozóica. Interessante ainda é a pequena bacia alongada (braquissinclinal do Jatuara na) com sentido geral E-W em sedimentos do Grupo Beneficente, na extremidade leste do bloco Acari. Sua gēnese ē incerta, mas uma hipötese seria de formação por interferência de fraturamentos NE (falha Maracanã-Urucu) e NW, prōximo a cuja interseção a bacia se encontra. Isso explicaria o porque de sua direção E-W, diversa das demais grandes estruturas da região.

VI.1.3. Bloco Aripuanã

0 bloco Aripuanã dispõe-se no sentido geral NW- 
SE e constitui-se na feição geomörfico-tectônica individual de major extensão.Seus limites para sul e oeste não foram determinados, mas a E-NE é limitado claramente peio falhamento do Aripuanã, entrando em contato com os blocos Camaiu, Acari, Matrin chão ebloco Juruena. Formado principalmente por rochas do Complexo Xingu, acha-se recoberto pela Formação Prosperança a $S W$ e por restos Grupo Uatumã no centro e a leste. Sua individualização como bioco tectônico, parece ter-se dado durante épocas de reativação, com a separação do bloco Acari, e o adernamento para SW ou S do bloco Aripuanã. Restos da Formação Prosperança es parsos na sua porção SW, prōximo ao rio Aripuanã, parecem comprovar esta tese, visto que a inclinação mencionada possibilita ria a erosão a NE das unidades a ele sobrejacentes (Uatumã, Beneficente (?), Prosperança).

As feições estruturais mais marcantes do bloco Aripuanã tem direção NW-SE, contrastando com a anteriormente descrita para o bloco Acari. Estas feições compreendem grandes falhas, fraturas e lineamentos paralelos ao rio Aripuanã que não penetram nos outros componentes tectōnicos da região. Incluem tambēm, sobretudo na porção SE, falhamentos expressivos de direção NE-SW, que se estendem nas unidades vizinhas, bloco Aca ri e bloco Juruena.

Tais Tineamentos são tanto mais evidentes quando situados em zonas tectónicas, como ao sul da confluência dos rios Guariba com o Aripuanã, e entre esse e o rio Roosevelt, a NW de Araras e Nova Vida, a oeste e fora da ärea aqui considera da.

Embora não existam dados suficientes para. de. monstrá-10, os falhamentos NW-SE parecem do tipo de deslocamento longitudinal, enquanto os $N E-S W$ adquirem feições de falhas normais. E de se notar, no entanto, que a falha do Aripuanã, em sua porção SE na altura do alto rio Moreru, ao se bifurcar no seu ramo W-E (falha do Cachimbo) aparenta ser francamente inver sa, atestando a presença de esforços compressivos em al guma ēpo ca da evolução geolögica regional. 


\section{VI.1.4. B10co Matrinchão}

O bloco Matrinchão ocupa a porção sudeste da regiāo. Desenvolve-se com sentido geral NW-SE. A norte $\bar{e}$ limitado pela faliha do Cachimbo,onde entra em contato com o bloco Juruena. A sudoeste este bloco faz limite com o bloco Aripuanã atravēs do falhamento do Aripuanã. Seus limites a leste não foram determina dos.Constitui-se predominantemente de rochas vulcānicas e plutōnicas do Grupo Vatumã que se dispõem èm uma larga faixa continua de direção $W-E$ abaixo da falha do Cachimbo, secundariamente por rochas do Complexo Xingu na sua porção sul e esparsos remanescen tes' do Grupo Beneficente. 0 seu contato com os sedimentos do Grupo Benficente situados a norte se faz atravēs da falha do Cachimbo que é de natureza inversa, onde o bloco $\mathrm{N}$ subiu sobre o bloco S, provocando a formação no Grupo Beneficente de amplos sinclinais e anticlinais com eixos de dobramento de direção WNWESE, como os que aparecem nas cabeceiras dos rios são Tomé e Moreru:Aparecem ainda, no bloco Matrinchão falhas e fraturas de direçäo NW-SE e NE-SW que adentram naş outras feições tectōnicas da região, portanto mais novas, que por vezes alojam extensos diques de rochas bäsicas.

\section{VI.1.5. Bloco Juruena}

o bloco Juruena ē a principal feição tectōnica da área, que se destaca dos demais pelas suas particularidades lito -estruturais. Apresenta unidades estratigräficas como o Grupo Beneficente, Formação Prosperança e a Suite Intrusiva Cinco Ilhas parcial ou totalmente circunscritas nele. Estruturalmente o bloco se ressalta pela presença de grandes ondulações,que configuram domos e anticlinais, com sinclinais intermediärios de fundo chato,bem como por dobras prōximas a fallhas:São eles, domo do Sucunduri,anticlinal do Juruena, sinclinal do Sucunduri-Bararati,sin clinal do São Tomé, domo do Juruena, domo do Anil, anticlinal Pedra Branca,braquianticlinal Cangucū e branquianticlinal Munduru cus,esses dois $\vec{u} 1$ timos aparecem alojados no anticlinal Munduru cus que è uma estrutura de la.ordem. Destaca-se ainda, com estrutu ra tafrogenética o graben do Maracanã.

Alēm dessas outras feiçōes tectōnicas menores mos tram-se marcantes no bloco como o anticlinal do Urucu, sinclinal 
do Urucu,braquissinclinal Apiacas e uma série de sinclinais e an ticlinais conjugados nas cabeceiras do rio Moreru.

A NW limita-se com o bloco Acari pela falha Maracanä-Urucu,a sudoeste com o bloco Aripuanã atravēs do falhamento Aripuanã e ao sul atravēs da falha do Cachimbo com o bloco Matrinchão.Seus limites a norte e Teste não foram reconhecidos.

\section{VI.1.5.1. Domo do Sucunduri}

0 domo do Sucunduri è a feição estrutural mais marcante do bloco Juruena.Possui uma forma circular quase perfei ta e conspícua em mais de $2 / 3$ de sua dimensão, achando-se inter rompida a NW pela Falha Maracanã-Urucu,atravēs da qual entra em contato com o bloco Acari.

Constituīdo dominantemente por rochas vulcānicas do Grupo Vatumã, apresenta-se recoberto em parte a NW por sedi mentos de Formação Prosperança. Na estrutura aparecem vārios tipos de rochas alcalinas, aflorantes em pelo menos 8 locais, os dois maiores corpos constituem corpos isolados, ou um único corpo não totalmente exposto atravēs das vulcānicas.Afora a ocorrēncia do rio São Tomē, atẻ o presente não hä outras ocorrēncias conhecidas de intrusivas alcalinas, na região em apreço.

Ao redor da estrutura dómica e recobrindo-a parcialmente em mais de $2 / 3$ de sua extensão, dispöem-se, à maneira de "cascas-de-cebola",os sedimentos arenosos, argilosos, conglomeräticos e calcíferos do Grupo Beneficente.

As principais estruturas disruptivas nesse domo são os falhamentos NW-SE e NE-SW, entre os Ü7timos destacam-se, a 1ëm da citada falha Maracanã-Urucu, as falhas preliminarmente denominadas de Paneiro e Cinco Ilhas. As duas primeiras balizam o graben do Maracanã.

Os 1 imites desse domo são bem determinados a NW, como se disse, bem como a SW, $S, S E$ e $E$. No entanto,a $N$ e NE, Ca so se considerar os sedimentos do Grupo Beneficente locais co- 
mo parte integrante da estrutura, estes limites se tornam obscuros, devido a existēncia de vārios paleoaltos (janelas estrutu rais).

\section{VI.1.5.2. Sinctinal Sucunduri-Bararati}

0. sinclinal Sucunduri-Bararati situa-se na parte central do bloco. Trata-se de um dobramento com mais de $100 \mathrm{~km}$ de extensão no sentido geral NE, ao sul, infletindo para $N$, ao norte, desenvolvendo-se principalmente ao longo do curso do rio Bararati. O dobramento afeta sedimentos do Grupo Beneficente (e com toda certeza as vulcānicas do Grupo Uatumã). Sua conformação em essência paralela ao contorno do domo do Sucunduri,faz pensar num dobramento condicionado a estrutura dômica, pelo menos na porção a ele prōxima. Na ärea, são frequentes os diques de rochas bāsicas com direção NE e NW, diques estes com mais de 10 $\mathrm{km}$ de extensão visível nas imagens de radar.

\section{VI.1.5.3. Anticlinal do Juruena}

0 anticlinal do Juruena dispõe-se na porção centro-leste da ärea. Constitui uma estrutura que apresenta direção geral $\mathrm{N}-\mathrm{S}$, que se estende por mais de $35 \mathrm{~km}$, desde a encosta sul da chapada do Cachimbo, na altura do baixo rio são João da Barra (Matrinchão) atē a porção sul do domo do Juruena. No seu segmento meridional alcança cerca de $25 \mathrm{~km}$ de largura e acha -se truncado pela falha do Cachimbo, e no setentrional forma um periclinio que constitui a sua parte terminal. Esta estrutura afeta sedimentos do Grupo Beneficente, expondo as suas camadas in feriores do longo do curso do rio Juruena,que o secciona grosso modo na parte axial e terminal ao norte.

\section{VI.1,5.4. Sinclinal do São Tomê}

Localiza-se no leste da ārea, constitui uma estru tura não compensada dobrada de fundo chato, com mais de $170 \mathrm{~km}$ de extensão, que tem forma grosso modo de um bumerangue, cuja con cavidade acha-se voltada para NE. Seus limites orientais situam- 
- se nas redondezas da ilha Guandu no rio Teles Pires, fora da ārea considerada, de onde segue inicialmente com sentido WNW atêe o trecho inferior do alto rio São Tomé, a $\bar{\imath}$ inflete para NWN, acompanhando todo seu médio curso,para depois cruzā-lo no seu baixo curso e seguir até as proximidades da ilha do vapor no baixo rio Juruena. Aparentemente a sua conformação é devida a dois sistemas de dobramentos, o primeiro de direção geral NWNSSE que originou o anticlinōrio Mundurucus $\bar{e}$ devido provavelmen te a um cordão de corpos igneos, que não protrudiram. o Grupo Bene ficente e que geraram o domo do Juruena, braquianticlinal Cangu ç, e domo Mundurucus no seu flanco esquerdo e bem como o domo do Anit eo anticlinal Pedra Branca: pelo seu flanco NE, e o segundo de direção WNW-ESE paralelo ao eixo do anticlinal e sin clinal dos Apiacas, que são estruturas aparentemente formadas pe 10 movimento inverso da falha do Cachimbo.

\section{VI.1.5.5. Anticlinal Mundurucus}

E uma estrutura de dobramento de primeira ordem que foi reconhecida pela Mineração Itaiba $S / A$ na qual se incluem outras duas estruturas de segunda ordem os braquianticli nais Canguçu e Mundurucus, o üttimo abriga o maciço alcalino homônimo.Sua direção geral é NWN-SSE, quase paralela ao sincli nal do São Tomê, estende-se por cerca de $90 \mathrm{~km}$, desde o trecho inferior do alto rio são Tomé, ate o interflüvio dos rios Bararati e Juruena, na altura do paralelo do lugarejo Esperança. 
VII. CONSIDERAÇOES FINAIS E CONCLUSÖES

Com base nos dados apresentados nos capjutuios pre cedentes pode ser admitida para a região em foco a coluna estrat $\underline{j}$ gräfica que aparece na Figura 12, bem como a seguinte evolução geolögica, esquematizada dentro da forma sequencial:

\section{Reconhece-se radiometricamente como}

rochas mais antigas da região, os granitos e granodioritos que afloram no bloco Matrinchão cuja idade $\mathrm{Rb} / \mathrm{Sr}$ em rocha total em isōcrona dè referència è de $1977 \pm 67 \mathrm{~m} . \mathrm{a}$., e para cujo embasamento consti tuído de gnaisses tonaliticos, dioriticos e metanoritos não se dispōe de dados geocronolögicos. Assim sendo, admite-se que esse segmento da ārea representa a porção SW da Provincia Amazōnia Central de Cordani et al (op.cit.) ou um nücleo crustal antigo consolidado no fim do ciclo Transamazōnico.

2. No bloco Aripuanã, os gnaisses e migmatitos que aparecem entre a extremidade sul da i Tha Comprida e Ariel, acusaram em isōcrona de referéncia $\mathrm{Rb} / \mathrm{Sr}$ idade de $1760 \pm 42 \mathrm{~m} . \mathrm{a}$.. Esta idade $\bar{e}$ considerada por Cordani et al (op.cit.) e Tassinari (op.cit.) como representativa da principal fase de metamorfismo (sintectōnico)regional da faixa mōvel Juruena-Rio Negro na qual se insere o bloco Aripuanã. Ainda, segundo o $\bar{u} 1$ timo autor essa fái xa teria se formado através de um super evento de acreção crustal.

3. Posteriormente, na região oeste da ārea, na faixa compreendida entre o baixo rio Maracanã e alto rio Buiuçu,ocor reram intrusões de biotita granitos röseos, por vezes estaniferos, sotopostos as rochas vulcānicas mais antigas, e que aparecem pröximo ao cruzamento de grandes sistemas de falhas, Maracanã-Urucu e Aripuanã, ou entre fathas sub-paralelas como as de Samaúma e Buiuçū.

4. Segue-se uma intensa erup̧ão de lavas ācidas e intermediārias de carāter continental na região dos rios AcariUrucu e Juruena, representadas respectivamente por riólitos, lati tos e andesitos, e por riölitos, dacitos, ignimbritos e brechas 
vulcănicas, cujas idades obtidas pelo mëtodo Rb/Sr em isōcronas de referéncia acusaram valores em torno de $1680 \mathrm{~m} . \mathrm{a}$.. Sendo suce dida por uma fase magmätica intrusiva mais tardia, representada principalmente por albita-microclinio granitos e granitos porfir $\underline{i}$ ticos no rio Juruena, e por granitos alasquiticos e granófiros na região do rio Acari.

5. Recorréncia da ativiodade vulcânica ácida-inter mediāria continental, na região hoje compreendida pela parte interna do domo do Sucunduri, cuja idade em isōcrona Rb/Sr de referência acusou $1641 \pm 14 \mathrm{~m}$. a., caracterizada litologicamente por riolitos, riolitos pōrfiros subvulcānicos, riodacitos, dacitos, andesitos, ignimbritos, brechas e aglomerados vulcānicos, tufos e tufitos, e por produtos de retrabalhamento hidrotermal pós-magmático das vulcānicas como quartzitos secundārios e por veeiros de quartzo hidrotermal de uma fase mais tardia.

6. Intrusão de rochas granīticas subvulcānicas no domo do sucunduri. Processo de greisenização tardi-subsequente dos granitos e vulcānicas da região do Acari.

7. Magmatismo básico expresso principalmente por corpos filonares de diabäsio e secundariamente por pequenos derrames de basaltos, cujas melhores exposiçóes situam-se no rio Aca ri a jusante da cachoeira das Andorinhas. A idade radiométrica $K /$ Ar indicou $1649 \pm 30 \mathrm{~m} . \mathrm{a}$. para essas rochas.

8. Deposição do Grupo Beneficente em mar epiconti nental, que transgrediu de leste para oeste. os dados obtidos atē agora em termos de características litolögicas, biolögicas, sedimentares (estruturas, tipos e dimensões), persistēncia geogräfica dos tipos litolögicos indicam um ambiente plataformal de sedimentação do Grupo Beneficente. No entanto, Basei (op.cit.), Cordani et al. (op.cit.), Tassinari et al (op.cit.) e Tassinari (op.cit.) consideram que o Grúpo Beneficente representa sedimentos molassōi des,formados durante a fase de inversão da faixa mōvel Juruena -Rio Negro. Torna-se portanto, necessārio um estudo mais detalhado do Grupo Beneficente para caracterizar o seu ambiente tectón co de sedimentação. 
9. Intrusão de rochas bäsicas fitonares com dire ção predominante $\mathrm{NE}-\mathrm{SW}$ na parte interna do domo do Sucunduri, e que cortam 0 Grupo Beneficente e cujas idades radiomëtricas K/Ar acusam $1493 \pm 22$ m.a..

10. Intrusão de rochas alcalinas da suite Intrus va Cinco I Thas na parte central e SW do domo do Sucunduri (com idade radiomētrica $\mathrm{Rb} / \mathrm{Sr}$ em isöcrona de referēncia de $1447 \pm 15$ m.a..) bem como no médio rio São Tomé, provocando o dobramento das rochas sedimentares do bloco Juruena, atravēs de soerguimen tos isolados na forma de domos e braquianticlinais,entre as quais aparecem sinclinais de fundo chato (com camadas horizon tais), tipificando um dobramento descontīnuo ou idiomōrfico.

11. Sedimentação do Grupo Prosperança em ambiente continental, em blocos tectonicamente deprimidos (graben do Maracanã) e em paleobaixos.

12. Recorrência do magmatismo básico na parte interna do domo do Sucunduri em diques de diabāsios finos, com fäcies basältico, datado em $1289 \pm 27 \mathrm{~m} . \mathrm{a}$.

13. Intrusão de rochas bäsicas ao longo e nas proximidades da falha Maracanã-Urucu, representadas no rio Urucu por um cordão de diques alinhados de diabāsio com idade radiomëtrica de $909 \pm 10 \mathrm{~m} . \mathrm{a}$., e no rio Maracanã por diques de olivina diabāsios e pequenos "stocks" de olivina gabro e gabro com idade K/Ar de $890 \pm 15 \mathrm{~m} . \mathrm{a}$.

14. Movimento inverso da falha do Cachimbo, com o bloco Juruena subindo sobre os blocos situados a sul (Aripuanã e Matrinchãol provocando o dobramento das litologias do Grupo Beneficente. No entanto, os blocos meridionais, aparentemente estiveram em posição mais alta anteriormente, como se infere pe los residuais do Grupo Beneficente neles encontrados.

15. Sedimentação da Formação Bararati,cuja jdade é desconhecida, sendo admitida como fanerozóica. 
16. Intrusão de diques paralelos de diabásio com direção aproximada NE-SW, na região do igarapē Assunção com ida de situado no limite do triássico-jurāssico (205 $\pm 8 \mathrm{m.a.})$. 


\begin{tabular}{|c|c|c|c|c|c|}
\hline Era & Periodo & $\begin{array}{l}\text { Unidade Estratiaräfica } \\
\text { Grupo Formação }\end{array}$ & Simboio & $L i t \circ 1 \circ g i a^{\prime}$ & $\begin{array}{l}\text { Idade Absoluta } \\
\text { m.a. }\end{array}$ \\
\hline Mesozōico & $\begin{array}{l}\text { Jurässico } \\
\text { Triāssico }\end{array}$ & Diabās io Assunçāo & $\tau: J$ as & Diabäsios finos e më́dios em diques & $205 \pm$ \\
\hline \multirow[t]{2}{*}{ Paleozöico } & $?$ & Bararati & Fzb & $\begin{array}{l}\text { Conglomerados de metarenitos em matriz arenosa qrossei- } \\
\text { ra, arenitos bem classificados com cimento caulînitico }\end{array}$ & \\
\hline & Cambriano & Diabás jo Labirinto & $\varepsilon_{1}$ is & Diabāsios finos a grosseiros en diques & $565 \pm 6$ \\
\hline \multirow{14}{*}{$\begin{array}{l}0 \\
0 \\
\sim \\
0 \\
N \\
0 \\
\alpha \\
w \\
\sim \\
0 \\
\propto \\
a \\
a\end{array}$} & \multirow{6}{*}{ Superior. } & Diabāsio Urueu & $\mathrm{Pr}_{3}$ us & $\begin{array}{l}\text { Diques de diabäsios, olivina diabäsios, pequenos stocks } \\
\text { de gabros e olivina gabros }\end{array}$ & $909 \pm 10$ \\
\hline & & Diabăs io Bacaba & $\mathrm{Pr}_{3} \mathrm{bB}$ & Diabāsios finos em dique, com fäcies basāltico & $1289 \pm 27$ \\
\hline & & Prosperança & $\mathrm{Pr}_{3} \mathrm{P}$ & $\begin{array}{l}\text { Arenitos lito-feldspáticos finos a médios, às vezes con } \\
\text { glomeràticos, intercalados por silteitos a argititos ver } \\
\text { meihos. Na base conglomerado polimitico }\end{array}$ & \\
\hline & & Suite Intrusiva Cinco I thas & $\operatorname{Pr}_{3} \mathrm{C}$ & $\begin{array}{l}\text { Litchfielditos, mariupolitos, umptekitos, nordmarkitos, } \\
\text { pulaskitos, larvikitos, fonolitos, traquitos, microsie- } \\
\text { nitos, lus itanitos, latitos e bostonitos }\end{array}$ & $1447 \pm 15$ \\
\hline & & Otabāsio Sucunduri & $\mathrm{Pr}_{3} \mathrm{sB}$ & Diabãsios finos em diques & $1493 \pm 22$ \\
\hline & & Beneficente & $\operatorname{Pr}_{2: 3^{b}}$ & 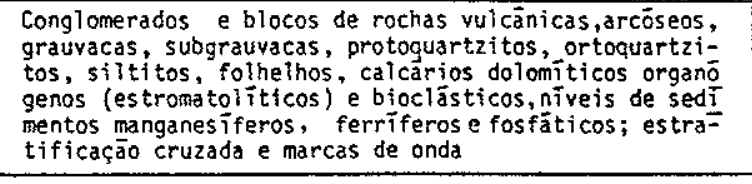 & \\
\hline & \multirow{7}{*}{ Med to } & \multirow[t]{2}{*}{ Diahäs lo Ancorinhas } & $\mathrm{Pr}_{2} \mathrm{aB}$ & $\begin{array}{l}\text { Diabäs fos finos a grosseiros em diques, basaltos em pe- } \\
\text { quenos derrames }\end{array}$ & $1649 \pm 30$ \\
\hline & & & $\operatorname{Pr}_{2}{ }^{u_{5}}$ & $\begin{array}{l}\text { Granitos pörfiros, greisens, peraciditos, granitos gra- } \\
\text { nofiricos e microgranitos }\end{array}$ & \\
\hline & & \multirow{4}{*}{$\stackrel{i 00}{\stackrel{100}{J}}$} & $\operatorname{Pr}_{2}{ }^{4}$ & $\begin{array}{l}\text { Riolitos, riälitos pörfiros, riodacitos, dacitos, ande- } \\
\text { sitos, ignimbritos, agiomerados e brechas vuicánicas, } \\
\text { tufos e tuf itos, quartzitos secundärios, atividade hi- } \\
\text { drotermal }\end{array}$ & $1641 \pm 14$ \\
\hline & & & $\operatorname{Pr}_{2}{ }^{4} 3$ & $\begin{array}{l}\text { Granitos, granitos alasquiticos, granitos pörfiros ou } \\
\text { porfiriticos, granitos greisenizados }\end{array}$ & $1679 \pm 19$ \\
\hline & & & $\operatorname{Pr} 2$ & $\begin{array}{l}\text { Riolitos, metarióistos, dacitos, metalatitos, latitos, } \\
\text { andesitos porfiros }\end{array}$ & $1688 \pm 23$ \\
\hline & & & $\operatorname{Pr} 21 y^{b} Y$ & Biotita granitos de granulação mëdia. & \\
\hline & & \multirow{2}{*}{ Complexo Xingu } & $\operatorname{Pr}_{2}^{x}$ & $\begin{array}{l}\text { Biotila e nuscovita anaisses, migmatitos, anfibolitos, } \\
\text { mi lonitos e rochas afins }\end{array}$ & $1760 \pm 42$ \\
\hline & Inferior & & $\operatorname{Pr}_{1}^{x}$ & $\begin{array}{l}\text { Grani tos, granodioritos, dioritos, metanoritos e gnais } \\
\text { ses tonaliticos }\end{array}$ & $1977 \pm 67$ \\
\hline
\end{tabular}


AGRADECIMENTOS

Durante a realização do presente trabalho contamos com a colaboração de diversas pessoas e entidades, aos quais o autor expressa seus mais sinceros agradecimentos.

o Prof.Dr. Umberto Giuseppe Cordani, empenhou- se pessoalmente acompanhando e discutindo com o autor todos proble mas relativos a presente dissertação.

o Prof.Dr. Koji Kawashita, do Centro de Pesquisas Geocronolögicas colaborou nos trabalhos de obtenção das idades radiomëtricas.

A Companhia Administradora Morro Vermelho do Grupo Camargo Corrēa, colocou a disposição do autor inümeras amostras de rochas para estudo geocronológico e dados de geologia re gional.

A Mineração Itaiba S/A do Grupo Icomi, forneceu dados e amostras referentes ao Maciço Alcalino Mundurucus.

Os Profs.Drs. Josê Moacyr Vianna Coutinho e Vicen te Antonio Girardi auxiliaram na descrição e exame petrográfico de Täminas delgadas.

A equipe administrativa e técnico-laboratorial do Centro de Pesquisas Geocronolögicas, constituĩda peios Srs. Clau dio Comerlatti, Claudio dos Santos, Jose Roberto Medeiros, Jos $\overline{\mathrm{e}}$ Elmano de Gouveia, Jorge Gouveia de Almeida e Key Sato, e pelas Srtas. Ivone Sonoki, Helen Sonoki e Margarida Martins, colaboraram durante as diferentes fases de obtenção dos dados analîticos.

A Sra. Melanie Thereza Isauk e o Sr. Claudio Hopp colaboraram com a jä costumeira eficiência, preparando todas as lāminas delgadas descritas neste trabalho.

A Sra. Claudete Salinas Franzosi que realizou os trabalhos de datilografia. 
A equipe do setor gräfico do Instituto de Geociēn cias da USP, especialmente em nome do Sr. Jaime Alves da Silva,pe la impressão e individualização dos exemplares. 


\section{BIBLIOGRAFIA CITADA}

ALMEIDA, F.F.M.de \& NOGUEIRA FILHO, J.V. - 1959.-Reconhecimento geolögico do rio Aripuanã. DNPM, Div.Geol. Miner., Bol.199, 43 pp. ilust.Rio de Janeiro.

ALMEIDA, F.F.M.de - 1974 - Evolução tectōnjca do Cräton do Guapọ re comparada coma do Escudo Bältico. Rev.Bras.Geoc., 4 (3): 197-204, São PauTo.

ALMEIDA, F.F.M.de; HASUI, Y. \& BRITO NEVES, B.B.de - 1976 - The Upper Precambrian of South America. Inst.Geoc. USP. BoT.IG. v.7: 48-80; São Paulo.

ALMEIDA, F.F.M.de - 1976 - A evolução dos crātons Amazónico e do São Francisco comparada com a de seus homōlogos do hemisfërio norte. Anais do XXX Cong:Bras.Geol. Vol.6, p. 2393-2407 Recife.

AMARAL, G.; CORDANI, U.G.; KAWASHITA, K. \& REYNOLDS, J.H.- 1966Potassium-argon dates of basaltic rocks from Southern Brazil. Geoch. et Cosmoch. Acta, 30 (2): 159-189.

AMARAL, G. - 1974 - Geologia prë-Cambrianá da região Amazōnica. Tese de Livre-Docência. Instituto de Geociências da Universidade de São Paulo. 2.12 p.

ARAUJ0. J.F.V.; DREHER, A.M. - 1974 - Rochas vulcānicas äcidas e subvulcānicas no leste da Amazonia. Anais do XXVIII Congr. Bras.Geol. 5: 161-170.

BASEI, M.A.S. - 1977 - Idade do vulcanismo ācido-intermediārio na região Amazōnica. Dissertação de Mestrado, Instituto de Geo ciēncias da Unịversidade de São Paulo. $133 p$.

BASEI, M.A.S. - 1978 - o Vulcanismo ācido-intermediārio na re gião Amazōnica. Anais do XXVIII Congr.Soc.Bras.Geol. Vol.6, pp.2408-2417, Recife. 
CAPUT0, M.V.; RODRIGUES, R.; VASCONCELOS, D.N.N.de - 1972 - Nomen clatura Estratigráfica da Bacia do Amazonas, Histörico e Atualização. Anais XXVI Congr.Bras.Geol. 3:35-46. Belēm.

CHANDLES; $W$. - 1862 - Notes on the rivers Arinos, Juruena and Tapajös. Geogr.Soc. J. London, 32: 268-280.

CORDANI, U.G. - 1970 - Idade do vulcanismo no Oceano Atlântico Sul. Bo1. IGA, 1: 9-75.

CORDANI, U.G.; KAWASHITA, K. e THOMAZ FILHO, A. - 1978 -

The applicability of the $\mathrm{Rb}-\mathrm{Sr}$ method to shales and related rocks. Am.Assoc.Pet.Geol. Studies in Geology no 6, "Contri butions to the Geologic Time Scale": 93-117.

CORDANI, U.G.; TASSINARI, C.C.G.; TEIXEIRA, W.; BASEI; M.A.S. \& KAWASHITA, K. - 1979 - Evolução Tectōnica da Amazōnia com Ba se nos Dados Geocronológicos. Actas do II Congr.Geol. Chileno J. 137-148. Arica, Chile.

CORDANI, U.G. - 1980 - Fundamentos de interpretação geocronolōgica. In:Interpretação de dados geocronolögicos. XXXI Cong. Bras.Geo1. Bol. ne 6:3-22.

COUTINHO, J.M.V. e SVISERO, D.P. - 1975 - Nota sobre algumas ocor rências de variscitas brasileiras. Gemologia, Vol.21, 41/42: $52 \div 56$.

COUDREAU, H.A. - 1977 - Viagem ao Tapajōs. Editora da Universidade de São Paulo, Livraria Itatiaia Editora Ltda. Belo Hori zonte. $162 \mathrm{p}$.

DALRYMPLE; G.B. e LAMPHERE, M. - 1969 - Potassium Argon Dating.W. H. Freeman and Co., San Francisco. 188p:

DAPPLES, E.C. - 1962 - Stages of diagenesis in the devolopment of sandstones. Geol. Soc.Am. Bul1. V. 73, p. 913-933.

EYSINGA; F.M. B.VAN - 1975 - Geological time table. Elsevier Scientific Publishing Company Amsterdam. 
FAURE, G. e POWELL, J.L. - 1972 - Strontium isotope geology Springer, Berlin, $188 \mathrm{p}$.

FAURE, G. - 1977 - Principles of Isotope Geology. John Wiley \& Sons, New York, $464 \mathrm{p}$.

FLORENCE, H. - 1875 - Esboço da viagem fejta pelo Sr. de Langs dorff no interior do Brasil, desde setembro de 1825 atē março de 1829. Inst.Hist.Geogr. Ethnogr Brasi1., Rev. Trimensa1; t. XXXVIII, Parte 1, p. 355-441; Parte II, p. 231-250. Rio de Janeiro.

FOLK, R.L. - 1959 - Practical petrographic classification of 1 i mestones. Am. Assoc. Pet. Geo1. Bu11., v.43, p. 1-38.

GARY, M.; MCAFEE JR., R. e WOLF, C.L. ed. - 1972 - GTossary of geology. American Geological Institute Washington, D.C. $805 p$.

GEBAUER, D. e GRUNENFELDER, M. - 1974 - Rb-Sr whole-rock dating of late diagenetic to anchimetamorphic, paleozoic sedimentsin southern France (Montaigne Noire). Contrib. Mineral. Pe trol. $47,113-130$.

HIGGINS, M.W. - 1971. - Cataclastic Rocks. U.S.Geol..Surv. Prof. Pap. 687. Washington 67p.

HURLEY, P.M. - 1959 - Authigenic versus detrital illite in sediments. Geo1. Soc.Amer. Bu11., V.70, no 12, p. 1622.

HURLEY,P.M., HEEZEN, B.C., PINSON, W.H., FAIRBAIRN, H.W. -1963 K-Ar values in pelagic sediments of the North Atlantic.Geo chim.Cosmochim. Acta v.27, no 4, p. 393-400.

HURLEY, P.M.; MELCHER, G.C.; PINSON, W.H.Jr. E FAIRBAIRN, H.W.1968 - Some orogenic episodes in South America by K-Ar and whole rock Rb-Sr dating. Can. J.Earth Sci., 5: 633-638.

IBGE - 1972 - "Novo" Paisagens do Brasit 2a.edição, Rio de Janei ro, $286 \dot{p}$. 
IBGE - 1977 - Geografia do Brasil. Região Norte, Vol.1, Rio de Janeiro, $466 \mathrm{p}$.

IBGE - 1977 - Geografia do Brasi1. Região Centro-0este, Vo1. 4, Rio de Janeiro, $364 \mathrm{p}$.

ISSLER, R.S.; ANDRADE, A.R.F.de; MONTALVAO,R.M.G.de; GUIMARAES, G.; SILVA, G.G.da \& LIMA, M.I.C. de - 1974 - Geologia. In: Brasil. D.N.P.M. Projeto RADAM. Folha SA.22 Belēm. Belēm (Levantamento de Recursos Naturais, 5).

ISSLER, R.S. - 1977 - Esboço Geolōgico - Tectōnico do Cráton do Guaporē. Rev. Bras.Geoc., 7(3): 177-211, São Paulo.

IWANUCH, W. - 1976 - Idades Rb/Sr das alcalinas do "Domo do Sucunduri", AM. XXIX Congr.Bras. Geologia, Resumos dos Traba Thos, p. 196. Ouro Preto.

JOHANNSEN, A. - 1931 - A descriptive petrography of the igneous rocks. Vol.I: Introduction, textures, classification and glossary. Univ. Chicago Press, Chicago, $318 \mathrm{p}$.

JOHANNSEN, A. - 1938 - A descriptive petrography of the igneous rocks. Vol. IV.: Feldspathoidal rocks and peridotites and perknites. Univ. Chicago Press, Chicago, $523 \mathrm{p}$.

KAWASHITA, K. - 1972 - 0 mëtodo $\mathrm{Rb}-\mathrm{Sr}$ em rochas sedimentares. Aplicação para as bacias do Paranä e Amazonas. Tese de Doutoramento, Instituto de Geociencias da Universidade de São Paulo, $111 \mathrm{p}$.

KUMPAN, A.S. ed. - 1974 - Manual metodolōgico para mapeamento geolögico na escala de 1:50.000. Tomo I. Nedra. 519 p.

LEAL, J.W.L.; SILVA, G.H.; SANTOS, D.B.dOS; TEIXETRA, W.; LIMA, M.I.C.de; FERNANDES, C.A.C. e PINTO, A.do C. - 1978 - Geolo gia. In: Brasil. Departamento Nacional da Produção Mirieral . Projeto Radambrasil. Folha SC.20 Porto Velho. Rio de Janeiro. (Levantamento de Recursos Naturais, 16). 
LIBERATORE, G.; ALECRIM, J.D.; MEDEIROS, J.B. de; MALUF, R.F.; PINHEIRO, S.da S.; ACHAO, S.M. \& SANTOS, J.0.S: - 1972 - Pro jeto Aripuanã-Sucunduri; relatōrio final, Manaus, DNPM/CPRM, 8 vols.

MANIZER, G.G. - 1967 - A Expedição do Acadēmico G.I. Langsdorff ao Brasil. Companhia Editora Nacional, Brasiliana. 329, São Paulo. 244 p.

MEHNERT, K.R. - 1971 - Migmatites and the Origin of Granitic Rocks. ELSEVIER PUBL. CO. Amsterdam. $405 \mathrm{p}$.

MONTALVAO, R.M.G. de, BEZERRA, P.E.L.; FERNANDES, C.A.C.; SILVA, G.H. \& PIMENTA, 0.N.S. - 1979 - Granitos pös-cinemäticos das folhas SB:20 - Purus, SC:20-Porto Velho e SC.21 - Juruena (Plataforma Amazōnica). In: Sociedade Brasileira de Geologia -Nūcleo Centro-0este. Bol. Informativo, 9: 73-147.

MONTALVAO, R.M.G.de \& BEZERRA, P.E.L. - 1980 - Geologìa e Tectōnica da Plataforma (Crāton) Amazônica (Parte da Amazónia Legal Brasileira) Rev. Bras.Geoc. 10 (1): 1-27.

MOORBATH, S. - 1975 - Geological interpretation of whole rock isochron dates from high grade gneiss terrains. Nature (Lon don), $255: 391$.

MOURA, P. de A. - 1932 - Reconhecimentos Geolögicos no Vale do Tapajōs. MA. Serv.Geol. Min., Bo1.67.53pp. Ilust. Rio de Janeiro.

MOURA, U.F. - 1980 - Projeto sulfetos na Serra do Urucu. Relatório Final. DNPM/CPRM. 01 . vol.

NICOLAYSEN, L.0. - 1961 - Graphic interpretation of discordant age measurements on metamorphic rocks - "Ann.N.Y. Acad.Scj" v.91, Art. 2: 198-206.

PETRI, S. - 1975 - Estratigrafia - Centro Paulista de Estudos Geolōgicos. São Paulo. $405 \mathrm{p}$. 
PETTIJOHN, F.J.; POTTER, P.E. e SIEVER, R. - 1972 - Sand and Sand stone. Springer-Verlag, Berlin-Heidelberg - New York.618p.

ROSA, H.;-PEREIRA, I.S.; DAMIANIK, R. \& ARAUJO JR, N. - 1966 - Ma nual de Geologia de Superfície.Ciēncia-Técnica-petrōleo. Seção: Exploração de petrōleo.Publicação nọ 2 ,CENPES-PETROBRAS, $126 p$.

SANTIAGO, A.F.; SANTOS, J.0.S. e MAIA, R.G.N. - 1981 - Estratigra fia preliminar da bacia sedimentar do Alto Tapajös. Anais do $X X X$ Congr.Soc.Bras.Geol. Vol.2, p: 786-797.

SANTOS, D.B.dOS; FERNANDES, P.E.C.A.; DREHER, A.M.; CUNHA, F.M.B. da; BASEI, M.A.S. \& TEIXEIRA, J.B.G. - 1975 - Geologia. In: Brasil. Depärtamento Nacional da Produção Mineral. F Projeto RADAMBRASIL Folha SB.21 Tapajōs. Rio de Janeiro (Levantamento de Recursos Naturais, 7).

SILVA, H.G.; LEAL, J.W.L.; SALUM, O.A.L.; DALL.AGNOL, R. \& BASEI, M.A.S. - 1974 - Esboço geolögico de parte da Folha SC.21 Juruena. Anais do XXVIII Congr.Bras.Geol., Vol. 4, p. 309-320.Porto Alegre.

SILVA, G.G.da; LIMA, M.I.C. de; ANDRADE, A.R.F.de, ISSLER, R.S. \& GUIMARAES, G. - 1974 - Geologia. In: Brasil.DNPM - Projeto RA DAM Folha SB.22 Araguaia e parte da Folha SC.22 Tocantins, Rio de Janeiro (Levantamento de Recursos Naturais, 4 ).

SORENSEN, H., ed. - 1974 - The Alkaline Rocks, JOHN WILEY \& SONS, NEW YORK - 622p.

SOUZA, A.M.M.; FARIA, C.A.S., LANDIM, J.do P.P. \& LEAL, J.W.L. 1979 - Reconhecimento Geolōgico no Limite Parā - Mato Grosso Projeto São Manuel. Brasil. DNPM. Geologia 9, Seção Geologia Bäsica, 6. 25p. Ilust. Mapas. Brasīia.

STEIGER, R.H. \& JAGER, E. - 1978 - Subcomission on Geochronology Convention on the Use of Decay Constants in Geochronology and Cosmochronology. Am. Assoc. Pet.Geol. Contributions to the Geologic Time Scale; Studies in Geology no 6: 67-72. Mi chigan, USA. 
STRECKEISEN, A. - 1967 - Classification and nomenclature of igneous rocks N.J.B. Mineral. Abh. 107, 144-240.

STRECKEISEN, A. - 1976 - To each plutonic rock its proper name. Earth-Science Reviews, 12:1-33, Amsterdam.

SUSZCZINSKI, E. - 1970 - La geologie et la tectonique de la Plataforme Amazonienne. Geo1. Rundsch. 59 (3): 1232-1253.

TASSINARI, C.C.G.; TEIXEIRA, W. \& SIGA JR. 0. - 1978 - Considera ções crono-estratigräficas da região das Chapadas do Cachim- bo e Dardanelos, Anais XXX Cong.Soc.Bras.Geo1. Vo1.1, p.477490. Recife.

TASSINARI, C.C.G. - 1981 - Evolução geotectōnica da provĩncia rio Negro-Juruena na região amazōnica. Dissertação de mestrado. Instituto de Geociências da Universidade de São Paulo. 99 p. (inēdito).

TEIXEIRA, W. - 1978 - Significação Tectōnica do Magmatismo Anorogēnico prē-Cambriano Bāsico e Alcalino na Região Amazônica, Anais XXX Congr. Soc. Bras. Geol. Vo1.1, p. 491-505. Recife.

TEREZO, E.F.de M.; GOES FILHO, L.; FERREIRA, H.de C.; VELOSO, H. P.; FONSECA, W.N. da \& SILVA, S.B. - 1975 - Vegetação. In: Brasil. DNPM. Projeto RADAM. Folha SB.21. Tapajōs, Rio de Janeiro (Levantamento de Recursos Naturais, 7).

TORquAT0, J.R. - 1974 - Geologia do Sudoeste de Moçamedes e Suas Relações com a Evolução Tectōnica de Angola. Tese de Doutoramento, Instituto de Geociēncias da Universidade de São Paulo $243 \mathrm{p}$.

VENTURA, L.M.; D'AVILA, L.M.; BARBOSA, G.V. - 1975 - Geomorfolo gie. In: Brasil.. DNPM. Projeto RADAM. Folha SB.21 Tapajós,Rio de Janeiro (Levantamento de Recursos Naturais,7).

WANLESS, R.K. - 1969 - Isotopic Age Map of Canada. Scale 1:5.000000 Can. Geol. Surv. Dep. Energy, Mines Resour, 1256A. 
YORK, D. - 1966 - Least-squares fitting of a straigh 1ine: Can. J.Phys. 44(5): 1079-1086.

BIBLIOGRAFI A CONSULTADA

BELOUSSOV, V. - 1968 - Structural Geology.Mir Publishers Moscow $179 p$.

BLACKADAR, R.G.; DUMYCH, H. \& GRIFFIN, P.J. - 1975 - Guide to au thors Can.Geol.Surv.Miscellaneous Report 16. $199 p$.

CAMV - CIA.ADM.MORRO VERMELHO - 1980 - Geologia da região compreendida entre a rodovia Transamazōnica e o segmento sul dachapada do Cachimbo, e os rios Roosevelt e Bararati. Rela törio Interno. Inëdito.

GEBRAUER, D.;GRUNENFELDER, M. - 1971 - Comparative Rb/Sr and $U / P b$ studies of migmatic ortho-and paragneisses. Ann. Soc. Geo1. Belgique. 94(2):14.

HENDERSON, J.B.; CALDWELL, W.G.E. \& HARRISON, J.E. - 1980 -North American Commission on Stratigraphic Nomenclature Report 8 Amendment of code concerning terminology for igneous and high-grade metamorphic rocks. Geol.Soc.Am.Bul1., Part I, v. 91 , p. 374-376.

IUGS Subcommission on the systematics of igneous rocks - 1973 plutonic rocks. Geotimes, $18,26-30$.

JAGER, E.; ZWART, H.J. - 1968 - Rb-Sr age determinations of some gneiss and granites of the Aston Hospitalet Massif (Pyre nees) Geol.Mijnbouw, 47, no 5, 349-357.

MONTOT0, M. - 1973 - Petrographic transformations in granitic rocks under tectonic stress. In:Lister, L. A. Symposium on gra nites, gneisses and related rocks.Geol.Soc.S.Afr. Johannesbourg, $509 \mathrm{p}$.

TUGARINOV, A.I. - 1966 - Causes of the formation of metallogenic provinces.in: Vinogradov A.P... ed.Chemistry of the earth's crust. Israel program for Scientific translations. $458 \mathrm{p}$. 


\section{ANEXOS - DESCRIÇOES PETROGRAFICAS}

$\cdot 1$

$W I-J-43$

Granodiorito

Gran. 0,5-3,0 mm

Plagiocläsio $A n_{20}(50)$, quartzo (30). microcli nio (15). Acessōrios e secundārios: biotita, sericita, epidoto, titanita (pardo rōsea), apatita e zircão (5).

Textura hipidiomōrfica levemente cataclasada. Apresenta granulação variāvel, predominando a grosseira constituída por plagioclāsio, quart zo e microciśnio em cujos intersticios ocorre biotita, sericita, epidoto e etc, ao lado de uma outra semi-porfirītica com" fenocristais de plagioclāsio em matriz grañ̄tica fane rítica fina.

2

$$
W I-J-44
$$

\section{Granito}

Gran. 0,5-2,0 mm

Plagioclāsio An 10-20 (35), microclínio (30), quartzo (30). Acessōrios e secundārios: bioti tita, opacos, zircão, titanita, muscovita, sericita e epidoto.

Textura hipidiomörfica pouco fraturada.

- Plagioclásio e microclínio em cristais mais ou menos retangulares em matriz granular pou co fraturada localmente micropegmatítica.

$3 \quad W I-J-53$

Granito

Gran. 0,2-1,0 mm

Microclīnio pertītico (30), plagiocläsio $\mathrm{An}_{20}$ (30) e quartzo (30). Acessōrios e secundārios biotita, opacos, titanita, apatita, muscovita -sericita e epidoto (10).

Textura hipidiomōrfica

$4 \quad W I-J-55$

Metanorito

Gran. 1,0-2,0 mm

ortopiroxênio, hornblenda, plagioclásio, bio- 
tita e quartzo secundārio.

Textura granoblästica mëdia.

0 piroxênio ocorre normalmente coroado por horn blenda, que se interpenetra com a biotita.Local mente aparecem cristais inalterados de piroxê nio.plagioclásio aparece constituindo cristais ripiformes.

5 $W I-J-57$

Tonalito

Gran. 0,5-03, mm Plagioclásio (50), quartzo (30), microcī́nio (5) e biotita (6). Acessōrios e secundārios:opa cos, apatita, epidoto, muscovita-sericita e etc.

Textura hipidiomörfica inequigranular.

Plagiocläsio com zoneamento normal An $40-20$ tende a formar cristais maiores em matriz granular de quartzo, plagioclásio e raro microclinio. os acessōrios tendem a se acumular intersticialmen te como em grauvacas.

$6 \quad W I-J-63$

Granodiorito (granito) porfiritico

Gran. 0,5-2,0 mm

Plagioclásio $\mathrm{An}_{20-5}$ (40), quartzo e microciinio (52). Acessōrios e secundārios: titanita., granada, biotita (verde), opacos, allanita, mus covita, epidoto e agregados saussurîticos.

Textura granular micro-porfiritica localmente micropegmatítica.

Plagiocläsio dos fenocristais com zoneamento normal $\mathrm{An}_{20-5}$, pouco fraturado, enquanto 0 da matriz sem zoneamento.

$7 \quad W I-J-64$
Granito (granodiorito) porfiritico-granofirico. Gran. 1,0-3 $\mathrm{mm}$ Plagioclásio, quartzo, microciōnio.

Acessōrios e secundārios: biotita, zircão, opa cos, apatita e epidoto.

Textura porfiritica e micropegmatitica. plagiocläsio dos fenocristais bem formado e zo- 
8 $W I-J-65$ $W I-J-66$

nado oscilatoriamente $A n_{30-10}(40)$ em matriz de quartzo, microclínio e plagiocläsio sem zoneamento. Biotita na forma de agregados.

Granodiorito (granito) porfiritico

Gran. 0,05-0,2 e 0,5-1,5 mm

Plagiocläsio, quartzoe microciínio (90)

Acessōrios e secundärios: biotita (pardo a ver de), titanita, opacos, apatita e epidoto (10). Textura porfiritica em matriz fina.

Plagiociásio An $40-20(40)$ na forma de fenocristais xenomorfos(ou quebrados e recristalizados) com zoneamento normal em massa fundamental de granulação fina, constituīda por quartzo e feldspatos (especialmente microclinio).

Granodiorito porfiritico

Gran. 0,05-0,1 e 0,5-3,0 mm

Plagioclásio, quartzo, microcīnio, biotjta, hornblenda. Acessōrios e secundārios: apatita, zircão, titanita e epidoto.

Textura porfiritica.

Plagioclāsio $\mathrm{An}_{35-10}$ forma fenocristais zonados oscilatoriamente, por vezes levemente manchado por albita.A matriz é granular fina de quartzo, microclïnio, plagiocläsio sem zoneamento, biotita (pleocroismo pardo a esverdea do) e epidoto.

Aparecem ainda com cristais maiores opacos, hornblenda (pleocroismo verde a azulado claro) e biotita.

10 WI-68 Granodiorito porfiritico

Gran. $0,1-0,2$ e $0,5-3,0$

Plagiocläsio $A_{30-15}$ (35), quartzo (30), micro clínio (20), biotita (10) e epidoto (5). Acessōrios: titanita, apacos, apatita.

Textura porfiritica com matriz fina.0 plagioclāsio aparece na forma de fenocristais ripiformes. A matriz é bem recristalizada poligo 
nal, constituỉda por plagiocläsio,quartzo, mi-· croclinnio, biotita, epidoto além dos acessōrios.

$11 \quad$ PT -07

Muscovita-epidoto-biotita gnaisse

Quartzo (20), plagiocläsio (20), microclínio(25), biotita (15), epidoto (10), sericita-mus covita (9).

Acessōrios: opacos, esfeno, apatita, zircão, turmalina (?).

Textura granolepidoblästica fina.

0 quartzo forma agregados de cristais com extinção ondulante entremeados aos feldspatos e mäficos ou ocorre em crescimentos mirmequiti cos e microgräficos com feldspatos. Plagioclá sio substituído por epīdoto, sericita-muscovita e micropegmatitos. Microclīnio anēdrico homogeneamente distribuĩdo. Biotita constituindo lamelas subédricas isoorientadas. Os opacos aparecem coroados pelo esfeno, zircão, apatita e por raros grãos de um mineral pleocrōico (azul a marrom clarol, possivelmente turmalina.

$12 W I-J-70$

Biotita gnaisse

Gran. 0,1-0,5 mm

Plagioclásio $\operatorname{An}_{20}(30)$, quartzo (30), microcī̄nio (30), biotita $( \pm 5)$. Acessōrios:titanita, a patita, opacos, muscovita, granada (poiquilo b]ästica).

Textura granoblástica, localmente granolepidoblästica.

Agregado granular de plagioclāsio, quartzo, mi crociinio e de biotita (com pleocroismo pardo a verde) lamelar isoorientada constituindo le tos localmente mais ou menos continuos.

$13 W I-J-71$

Muscovita gnaisse

Microclínio (45), plagioclāsio (15), quartzo (32), muscovita (5) e biotita (3). Acessōrios: opacos, apatita e titanita. 
Textura granocataclāstica com faixas grano-. blästicas.

Microclinio levemente pertïtico, frequente mente com geminação em grade. Plagioclàsio parcialmente sericitizado e localmente epido tizado. Biotita e muscovita em fiapos estira dos, discretamente orientados.

opacos irregulares (esquelēticos) concentram -se junto a biotita. Aparecem ainda intercrescimentos microscōpicos de quartzo vermicular com a muscovita.

$14 \quad W I-J-73$

Muscovita gnaisse milonitico

Gran. 0,1-0,3 mm

Microclínio (25), plagioclásio $\mathrm{An}_{20}$

e sericita-muscovita (10). Acessörios: bioti ta, clorita, titanita, epidoto e opacos.

Textura granolepidoblästica cataclasada. Quartzo, plagioclásio.e microclīnio formam um agregado bastante deformado de grãos arre dondados ou lenticulares. Intersticialmente a parecem fiapos bem orientados e estirados de muscovita (sericita), biotita e epidoto.

$15 \quad W I-J-75$

Biotita gnaisse cataciástico.

Gran. 0,2-2 mm

Quartzo, plagiociāsio $A n_{20}$ e microclīnio per tîtico (90); biotita (7). Acessōrios:opacos;. magnetita, muscovita e titanita (3).

Textura granoblästica a granolepidoblästica, cataclástica.

o quartzo, plagioclásio e microclīnio estão deformados e lenticularizados.

0 quartzo tende a um maior arredondamento que os demais minerais.

16 WI $-\mathrm{J}-77$

Biotita gnaisse porfiroblästico

Gran. 0,05-0,8 mm

Microclinio (39), quartzo (30) plagioclásio (20), biotita (8) e muscovita (3). 
Acessórios: opacos, zircão e apatita (2).

Textura: granoblástica cataclasada poligonal a interlobada.

Agregados de quartzo-feldspatos em pelo menos duas granulações destacadas, uma de ilho tas ou lentes na outra mais fina.

Augen-gnaisse (milonitico) leucocrātico

Gran. $<15 \mathrm{~mm}$

Plagioclāsio (antipertítico), microclínio, pertitico e quartzo (98). Acessörios:biotita, limonita e sericita (2)

Textura cataclástica augen ou flaser. Grandes porfiroclastos de plagioclásio (por vezes antipertitico) e microclinio pertitico rodeados por fitas de quartzo muito deformado e por faixas finas miloniticas.

18 WI-J-79 Biotita gnaisse cataclasado Gran. 0,5-2 mm Microclínio, quartzo, plagioclásio $\mathrm{An}_{20}(88)$, biotita (10). Acessórios: opacos, apatita,ti tanita (pardo rósea), zircão, granada e muscovita secundāria (2).

Textura granoblástica cataclasada.

Pequenos grãos,idiomōrficos de plagioclāsio nas bordas de cristais maiores de plagioclāsio desenvolvendo pontos triplos.

Intercrescimentos mirmequiticos no contato de plagioclásio e microclínio.

Biotita na forma de fiapos, homogeneamente espalhada e isoorientada.

Rocha mais bem recristalizada que as anterio res.

19 WI-J-80 Gnaisse granodioritico

Gran. 0,2-3 mm

01 igoclásio, quartzo e microclinnio pertítico (90); biotita (7). Acessōrios: opacos, titanita (pardo rósea), zircão, epidoto e serici 
ta (3).

Textura: granoblāstica interlobada.

Intersticialmente entre grãos maiores de oli goclásio e microclínio aparecem pequenos grãos idiomorfos de plagioclasio. Intercrescimentos mirmequiticos no contato do oligocläsio com o microclīnio, frequente quartzo deformado com extinção ondulante. Desenvolvi mento incipiente de sericita no plagioclásio.

Gnaisse granitico cataclasado

Gran. $0,2-0,3 \mathrm{~m}$

01 igocläsio (15), quartzo (35), microclīnio pouco pertitico (45) e biotita (3).

Acessōrios: opacos, titanita, apatita (pardo rōsea) e zircão (2).

Textura granoblästica cataclasada, mais deformada que a anterior.

Quartzo e plagioclásio com extinção ondulante. Grãos intersticiais de feldspato alcalino com pontos trïplices em volta de grãos majores de oligoclásio e microclinio. Intercrescimentos mirmequiticos entre oligocläsio e microciónio.

$21 W I-J-81 A$

Leuco-gnaisse granītico cataclasado

Gran. 0,5-0,3 mm

Microclínio (45), oligoclásio (18), quartzo (35). Acessōrios: biotita, titanita.

Textura granoblästica cataclasada, localmente com leitos exibindo textura mortar.

Quartzo e plagioclásio com extinção ondulan te. 0 plagiociásio com cristais corroìdos. Biotita deformada. Grãos intersticiais de -plagioclásio e feldspato alcalino com pontos triplos. Intercrescimentos mirmequiticos entre grãos maiores de oligoclásio e microclīnio. 
Leuco-gnaisse

Gran. 0,5-2 mm

Plagioclásio $\mathrm{An}_{20}$, quartzo e microclínio (90); biotita (6). Acessörios: titanita (pardo róseo) apatita, hornblenda (verde), zircão, epidoto, clorita e muscovita (2).

Textura granuloblāstica interlobada. Alguns cristais maiores de microclinnio incluem plagioclásio e glöbulos de quartzo.

Por vezes aparece glöbulos de quartzo e cristais de zircão inclusos no plagioclásio. Grãos maiores de quartzo zonado (envolvidos por faixas de quartzo). Intercrescimentos mirmequiticos no contato do oligoclásio e microciōnio.

Restos de plagioclásio mirméquitizado dentro do microciinio. Intersticialmente diminutos grãos de microclīnio e plagiocläsio.

$23 W I-J-84$

Granodiorito (granito) porfiritico

Gran. $0,05-3 \mathrm{~mm}$

Quartzo, plagioclāsio e microclínio (85); biotita (10). Acessōrios: titanita (pardo rōsea), epidoto, opacos, apatita e zircão (?).

Textura porfirîtica com matriz granuloblástica mëdia.

Fenocristais de plagioclásio $\mathrm{An}_{30-20}$ recristalizados imersos em matriz granitica (quartzo, plagiociásio, microciinio e biotita parda) de granulação heterogēnea e aparência metamōrfica.

24 PT-04A

Migmatito (melanossoma)

Hornblenda (39), plagioclāsio (60), piroxēnio esfeno, apatita, opacos, biotita, quartzo, ura lita, sericita.e argilo-minerais.

Textura granoblästica média

Plagioclásios anēdricos, raramente subēdricos, com maclas complexas predominando as polissintéticas (Albita e Albita-Periclina) nem sempre bem marcadas, devido a extinção ondulante e en 
curvamento dos planos de geminação. Em fraturas apresenta inclusões de anfibólio. Como produtos de sua alteração aparecem sericita e argilo-minerais. Hornblenda em cristais prismáticos, subëdricos com certa orientação, 10calmente envolve e substitui parcialmente cristais de piroxênio (diopsidio-augita). Este $\bar{e}$ levemente esverdeado sem pleocroīsmo,sub édrico, algo uralitizado. Esfeno associado ou incluído nos anfibólios. Apatita, opacos,biotita e quartzo como acessōrios.

25 PT-2IAA Riolito pörfiro

Plagiociāsio, feldspato potāssico, quartzo, apatita, zircão opacos. Secundários: clorita, óxidos de ferro, sericita.

Textura porfiritica.

os fenocristais são constituidos por plagioclāsio sericitizado imerso numa matriz quartzo-feldspätica bastante recristalizada.

29 WI-J-01 Brecha riolitica

Gran. 0,05-0,08 e 1,0-2,0 mm

Microclinio, plagioclásio e quartzo.

Textura pirociástica

Fragmentos de quartzo vulcânico, feldspato po tāssico (microclīnio de baixa triclinicidade) e raro plagioclásio albitico imersos em massa fundamental fina heterogênea e fluidal, em parte esferulitica.

Brecha (ou tufo vulcānico) latito-dacitica. Plagioclásio, feldspato potássico, clorita,epidoto e opacos

Textura piroclāstica-vitrofírica

Fragmentos de plagioclásio albitizado,subordi nadamente feldspato potássico em massa fundamental finissima, fluidal, leucocrätica e heterogênea. Raros clorita, epidoto e opacos. 
Tufo riolitico

Gran. 0,01-0,1

e $0,5-1,5 \mathrm{~mm}$

Quartzo, feldspato (?) argilo-mineral

Textura pirociástica

Fragmentos de quartzo bipiramidal (vulcānico) ao lado de outros quebrados e agregados em matriz finĩssima quartzo-feldspātica(?)argilosa.

Apresenta vênutas quartzosos.

32 .

$W I-J-60$

Dacito pörfiro

Gran. $<0,2$ e $0,5-3,0 \mathrm{~mm}$

Plagioclāsio, biotita, quartzo, opacos,epidoto, sericita, leucoxēnio

Textura granular fina porfiritica

Fenocristais constituĩdos de plagioclāsio algo sericitizados e por mäficos epidotizados e biotitizados. A matriz è muito fina leucocrätica com algum epidoto, biotita, le u coxênio e acha-se maculada com crescimento abundante de quartzo granuloblástico.

Gran. <0,3 e 0,5-1,0 mm

Microciänio, plagioclásio, quartzo. Acessórios: biotita, titanita, granada e epidoto Textura granular fina porfiritica

Fenocristais de microclinio de geminação muito fina, plagioclāsio albitizado e quart zo (vulcânico) em geral todos com aparência fragmentada; envoltos por massa fina quartzo-feldspātica, bem orientada fluxionarmente.

Granito

Gran $0,5-4,0 \mathrm{~mm}$

Albita $\mathrm{An}_{5}(30)$, microclīnio pertítico (40) quartzo (28). Acessōrios clorita, epidoto, muscovita, allanita (2).

Textura hipidiomörfica cataclasada. 
A albita é idiomorfa e epidotizada; microcitinio mais ou menos retangular a arredondado, ambos bastante fraturados e imersos em massa de quart zo mais fina poligonal.

35 WI-12 Microgranito

Gran 0,1-05 e 1,0-1,5 mm

Albita $\mathrm{An}_{5}(40)$, microclinio de baixa triclinici dade (20), quartzo (28). Acessörios:biotita e apatita.

Textura hipidiomórfica

A albita $\bar{e}$ mais ou menos retangular, de bordas irregulares (raramente em cristais milimétricos); quartzo irregular.

o epidoto, sericita e clorita aparecem na forma de aglomerações e saussuritizações.

35A WI-14 Microgranito (granito porfiritico) milonitizado Gran. 0,1-0,5 mm.

Albita, microclínio pertitico, quartzo, bioti ta, clorita, epidoto e opacos.

Textura xenomōrfica cataciástica

Predomina albita sobre o quartzo e o microcli nio. Tanto os cristais de albita quanto os de microclinio encontram-se sob forma anédrica.clo rita ocorre como produto de alteração da biotita.

Gran. 0,05-0,1 e 0,5-2,0 mm

Albita $\mathrm{An}_{5}$, microclínio, quartzo,allanita, bioti ta (verde), sericita, clorita, epidoto e aglomerados saussuriticos ( 80$)$

Textura porfiritica com matriz hipidiomörfica fina.

Fenocristais alterados (saussuritizados e recristalizados de albita ao lado do microclinio em massa fina de quartzo, feldspatos e concentrações saussuriticas. 
Granito porfiritico

Gran. matriz $<0,4$ e $2,0-4,0 \mathrm{~mm}$

Plagiocläsio, microclínio, quartzo e bioti ta

Acessōrios: titanita, zircão, apatita, alla nita, muscovita, opacos, clorita e mine rais do grupo do epidoto.

Textura porfiritica

Fenocristais de plagioclāsio subëdrico e a nëdrico, na maioria das vezes com gemina ção polissintética, por vezes com inclusões de quartzo; localmente acham-se substituĩdos por clorita e cristais enēdricos e subēdricos de epidoto.

A matriz è constituída por plagioclásio, quartzo e microclinnio. Este aparece em cristais límpidos com frequente geminação em grade. Biotita em cristais subëdricos a anēdricos junto a qual ocorrem associados zircão, apatita, titanita, opacos, epidoto e clinozoizita.

Granito porfirítico

Gran. 0,1-0,2 e 0,5-1,5 mm Albita $\mathrm{An}_{5}(50)$, quartzo (30), microclinio (10).

Acessōrios e secundārios:biotita,titanita, apatita,opacos e epidoto (10).

Textura porfirītica com matriz hipidiomōrfica fina.

A albita aparece em parte epidotizada e se ricitizada, tendo a forma retangular imersa em massa granular mais fina de quartzo, microciinnio e concentrações de biotita(com inclusões de titanita), apatita, opacos e epidoto. Aparentemente $\bar{e}$ um quartzo-diorito ou granodiorito albitizado. 
Plagioclásio An $30-10$, quartzo, microclínio, hornblenda, biotita, apatita, zircão, titanita e epidoto.

Textura porfiritica com matriz hipidiomörfi ca.

Fenocristais de plagioclásio $\mathrm{An}_{30-10}$ com zo neamento normal, aparentemente foram recris talizados em parte, junto com a matriz granoblāstica de quartzo, plagioclásio,microclinio, biotita (pardo esverdeada) e epidoto. Hā tambēm cristais maiores de opacos (magnetita) e hornblenda (verde azulado cla ro).

40 WI $-J-48$

Granito pórfiro

Plagioclásio, microclinio, quartzo e biotita

Acessōrios: zircão, titanita, apatita e opa $\cos$

Secundärios: epidoto, clinozoizita, zoizita e clorita.

Textura porfiritica

Fenocristais de plagioclásio parcialmente alterados e substituídos por minerais do grupo do epidoto (euedral a anédrico), seri cita e quartzo, que the conferem aspecto poiquilitico. A matriz è xenomōrfica de gra nulação fina constituída por quartzo, micro clínio (com extinção ondulante), plagioclāsio, biotita e etc. A apatita ocorre na for ma de bastonetes. Junto a biotita concen tram-se os opacos, e por vezes junto aos opacos os minerais acessörios. A rocha mos tra indicios de deformação pela presença de cristais fragmentados, planos de geminação acurvados nos plagioclásios.

41 WI-J-49 Granito porfiritico

Gran. $0,02-0,5$ a $0,5-3,0 \mathrm{~mm}$ 
Plagioclásio An $10-20$, quartzo, microciínio, biotita, muscovita.

Textura porfiritica com matriz hipiomōrfica Plagiociásio An $10-20$ com zoneamento inverso forma cristais retangulares na massa fundamental de quartzo, microclinio, biotita(par do a verde) que aparece localmente concentrada e muscovita. Na massa fundamental hä $\bar{a}-$ reas mais grossas de $0,2-0,5 \mathrm{~mm}$ de quartzo e microclinio.

\section{Granito porfiritico}

Gran. 0,02-1,0 e 1,0-3,0 mm

Plagioclásio $A n_{40-20}(30)$, quartzo (30), microclinio (30). Acessörios e secundārios: biotita, opacos, titanita, apatita, zircão, muscovita e epidoto (10).

Textura porfiritica em matriz hipidiomōrfica:

43 WI-J-GA Granito leucocrätico

Plagioclásio (oligoclásio), microclínio per títico e quartzo. Acessörios. biotita, zircão e opacos. Secundārios: epidoto e serici ta.

Textura hipidiomórfica inequidimensional. Plagiociásio subēdrico com zoneamento normal, quase totalmente substituído por sericita e por vezes pelo epidoto. Microclínio. pertitico sem geminação em grade, com pontos de argilo-minerais. Biotita muito cloritizada, por vezes totalmente. 0 quartzo $\bar{e}$ anēdrico pobre de inclusões.

\section{Granito}

Gran. 4-6,0 mm

Plagioclásio, feldspato alcalino, quartzo. Acessōrios: apatita, zircão, opacos e fluorita. 
Secundärios: leucoxēnio, clorita e saussuri-. ta.

Textura granular-alotriomörfica

Feldspato alcalino em cristais anédricos comumente pertítico; albita-oligoclásio em geral com o nūcleo mais saussuritizado que a borda. Quartzo em grãos tambēm equigranuia res com extinção ondulante frequente. Fluori ta em massas menores que $0,1 \mathrm{~mm}$, geralmente inclusa no feldspato.

\section{Granito}

Gran. 3,0-10,0 mm

Plagioclásio, feldspato alcalino,quartzo bio tita (marrom), apatita, titanita, zircão,anfibōlio (hornblenda), leucoxênio, pirita e outros opacos.

Textura alotriomōrfica.

Feldspato alcalino geralmente pertitico em cristais de até $10,0 \mathrm{~mm}$, por vezes envolto por plagiocläsio, numa textura rapakivi.plagioclásio (albita-oligoclásio) saussuritizado segundo o zoneamento do cristal. Quartzo em grãos anēdricos, atingindo as vezes quase $10,0 \mathrm{~mm}$, com forte extinção ondulante.

Granito-granöfiro

Gran. 0,5-1,5 mm e 2,0-2,5 mm Microclínio e quartzo (65), plagiocläsio(20) muscovita (10), opacos (5). Acessōrios:grana da e pirita e leucoxênio.

Textura porfiritica e microgrāfica Quartzo por vezes ocorre na forma de fenocristais arredondados. Muscovita em palhetas muito bem desenvolvidas.

Abundantes intercrescimentos microgräficos (granofiricos) embora existam cristais independentes de quartzo e microclinio. Rocha metassomatisada e recristalizada. 
Riolito (microgranito) pörfiro greisenizado Gran. 0,01-0,03

Microclinio, quartzo, muscovita, biotita e opacos.

Textura microporfiritica

Raros microfenocristais de microciinnio em matriz quartzo-feldspätica finissima, sem dūvida recristalizada.

Opacos, biotita e muscovita (em palhetas $1 \mathbf{i}$ ir pidas, bem desenvolvidas, tardias) espalhados.

47a $\quad P-3479$ Granōfiro-granito fino

Microclínio e quartzo (75), plagioclásio (1015), muscovita (10). Acessōrios: opacos

Textura microgrāfica

Rocha constituida por abundantes intercrescimentos microgräficos (granofiricos) ao lado de cristais independentes de quartzo e microclínio. Muscovita aparentemente primāria.

47b L-342 Granito

Gran. $0,3-1,0 \mathrm{~mm}$ e 2,0-8,0 $\mathrm{mm}$

Microclínio (45), quartzo (30), plagioclásio (15), biotita (8). Acessōrios: zircão, apatita, allanita e magnetita. Secundärios: serici ta, clinozoizita, leucoxênio e ōxidos de ferro.

Textura hipidiomörfica granular

Tendendo a porfiritica e granofirica

Grandes cristais de microclinio, intensamente pertitico, englobando ou associado a plagio clásio (oligociásio) alterado, retangular e quartzo, este tendendo a bipirämides. Externa mente aos microciinnios formam-se zonas micropegmatíticas. Massa fundamental fina de micro clínio, oligocläsio e quartzo. Biotita em cristais grandes cinza esverdeados, manchados de pardo. Apatita e zircão são acessōrios nor mais. Máfico alterado em öxidos de ferro pare ce ter sido allanita. 
47c VM-5 Biotita granito

Gran. 0,5-0,7 mm e 10,0-20,0 mm

Microclänio (50), plagiocläsio $\mathrm{An}_{20-5}(20)$, quart zo (15), biotita (7-10). Acessōrios: zircão,esfeno, apatita e opacos.

Secundärios: clorita (penina), argilo-mineral e agregados saussuriticos.

Textura porfiritica.

Microciinio em cristais muito grandes (porfiroblastos) e na matriz anēdrica-subēdrica, com a bundantes pertitas (patch ou string). Plagiocláa sio euëdrico e subëdrico, zonado oscilatoriamen te (ritmicamente), bastante saussuritizado, maclado segundo lei da Albita e Albita-Periclinio ocorrem cristais positivos e negativos. Quartzo anēdrico.

$47 d$

P-4303 Granito, alasquitico

Gran. 3,0-5,0 mm

Quartzo (25), plagiocläsio (20), microclínio (50), biotita (5). Acessōrios: esfeno, apatita, opacos.

Secundärios: saussurita

Textura granular hipidiomōrfica

o microclínio ē pertitico, bem maclado segundo Albita-Periclinio, Carlsbad e Baveno; substitui o plagioclāsio (oligoclāsio), o qual se apresen ta em cristais corroidos, as vezes bem saussuri tizados exibindo geminação polissintētica, zona ção pouco acentuada. 0 quartzo è anëdrico com extinção ondulante as vezes intercrescido com o microciinio. o opaco presente exibe coroas de esfeno.

47e P-7445 Riolito pörfiro cornubianitizado, greisenizado Quartzo e microclīnio (65), muscovita (20), biotita (5), opacos (10). Secundārios: leucoxēnio e argilo-mineral.

Textura pōrfira, orientada. 
A rocha sofreu ação metassomática,expressa pe la muscovitização. Apresenta como indícios de ação termal (textura de metamorfismo de contato)aureolas de teucoxēnio nos opacos.

$47 f$

$47 \mathrm{~g}$

$L-352$

Gran. mēdia 1,2-1,8 mm

Quartzo (60), topāzio (25), pirita (1), magne tita (1) e mica litinifera (3)

Textura granoblästica-xenoblästica

Quartzo e topäzio xenobiásticos em textura pa vimentosa engrenada e placas menores de mica branca, possivelmente litinïfera (zinnwaldita) Um.grão de mineral acessōrio cinza pardacento, de altīssimo relevo, uniaxial positivo, pode ser zircão ou cassiterita.

Limonita preenche fissuras, fraturas. linhas de clivagem e espaços intergranulares.

$47 \mathrm{~h}$ $S-807$
-Greisen quartzoso

Gran. $0,2-4,0 \mathrm{~mm}$

Quartzo (95). Acessōrios: muscovita, fluorita (roxa), albita e opacos. Secundārio:anatásio. Textura inequigranular xenoblästica Quartzo em cristais xenomorfos,alongados com 
extinção ondulante, ao que parece devido a fenōmenos tectōnicos. Fluorita e o acessōrio mais abundante em pequenos cristais com $3 \mathrm{cl} \underline{i}$ vagens octaēdricas. Rara muscovita em peque nas placas.

Greisen quartzoso

Gran. $0,10-0,20$ e $0,8-1,5 \mathrm{~mm}$

Quartzo (95). Acessōrios: fluorita, muscovita, plagiocläsio (albita?), zircão,molibdenita, ru tilo.

Textura inequigranuiar.

Quartzo anëdrico, suborientado, com extinção ondulante. Muscovita em pequenos e esparsos cristais. Plagioclásio (albita?) em pequenos e raros cristais bem geminados.

Rutilo acicular incluso no quartzo. Fluorita roxa, ocorre em cavidades e exibe muito bem suas clivagens octaēdricas. Zircão em cristais euëdricos. Värios cristais opacos peque nos com häbito lamelar provavelmente de molib denita.

47j VW-0/A Tufo äcido greisenizado, cornubianitizado (ro cha de contato)

Gran. $0,13 \mathrm{~mm}, 1,0-2,0$ e $10,0 \mathrm{~mm}$ Quartzo e microclínio (79), muscovita (5), bio tita (10), opacos (10). Acessōrios e secundārios: zircão, esfeno, cordierita (?), sericita, leucoxênio e argilo-mineral (1).

Textura porfiritica "fenoclästica"

Rocha bem estratificada, sendo o acamamento conferido pela diferença de composição e tamanho de grão. Alternam-se finos leitos mais guartzosos com leitos mais feldspäticos. Alguns fenoclastos atingem $2 \mathrm{~mm}$ de tamanho, en quanto fragmentos de rocha atingem quase 1,0 $\mathrm{cm}$. A rocha $\bar{e}$ muito recristalizada, apresen.tando alguns cristais bem desenvolvidos de biotita, microclinio e quartzo, os quais em. 
uma ültima fase foram substituidos por muscovita. Localmente feldspatos sericitizados e argilitizados. Opacos leucoxenizados. Em algumas camadas quase certamente cordierita poiquiloblāstica (fenoblasto).

$471 \quad V M-2$

Cornubianito

Quartzo, plagioclásio e microclínio (85),opacos (10). Acessōrios: muscovita (1itinîfe ra?) e granada. (5)

Textura granular fina xenomōrfica

Rocha de composição dacittica, predominando o plagiocläsio sobre o microclínio. Opacos como "poeira" espalhados por toda rocha. A granada $\vec{e}$ pecilitica, tardia e bem desenvol vida. 0 mesmo se dá com a muscovita. A asso ciação paragenētica bem como as relações de campo permitem formular a hipōtese que esta rocha tenha evoluído de uma vulcānica, que sofreu ação metassomātica (muscovitização) incipiente e um choque térmico responsāvel pela recristalização e formação da granada.

$47 m$

$\operatorname{MCS} / 488$

\section{Peracidito}

Gran. $0,5-1,5 \mathrm{~mm}$

Quartzo, topāzio, muscovita, opacos e .. óxidos de ferro.

Textura granular

Rocha formada por um mosäico granular de quartzo (mais abundante) e topázio de tamanho e forma bastante variäveis, com bordas reentrantes e por vezes intercrescidos, peIícula de ōxido de ferro, limita os grãos.0 quartzo apresenta-se sem deformação e sem ou muito pouca extinção ondulante. Muscovi ta ocorre em quantidade subordinada na forma de palhetas pouco desenvolvidas, por vezes reunidas em pequenos aglomerados. Os opacos são constituidos por ilmenita e magnetita (identificados por difração de raios $-X$ ). 
Plagioclásio $\mathrm{An}_{20}$, ortoclásio, quartzo, opacos e zircão.

Textura porfiritica (?) granofirica (?)

Cristais de plagiocläsio e de quartzo intersticial (em aglomerados) são rodeados por massa fina de quartzo-ortociásio, com evidente recristalizaçäo do quartzo e incipientes, intercrescimentos microgräficos (granofíricos). Possivel interpretação: brecha riolâtica recristalizada tendendo a riolito pörfiro.

Dacito pörfiro

Gran. 0,05-0,09 mm e 0,7-2,5 mm

Plagiociāsio, feldspato potássico, quartzo, pacos, pistacita, clorita, carbonatos, 1eucoxênio, argilo-mineral

Textura porfiritica fluidal

plagiocläsio e feldspato potässico formam fenocristais euédricos alterados em sericita,ar gilo-mineral, carbonato e epidoto. São comuns massas de esferulitos que podem atingir värios milimetros de tamanho, junto as quais aparecem intercrescimentos gräficos de quartzo e feldspato potássico. os opacos encontram-se bastante leucoxenizados.

50 $A M-18$

Tufo

Gran. $0,2-0,4$ e $1,0-2,0 \mathrm{~mm}$

Quartzo, plagiociásio, fragmentos lïticos(tra quito e vitröfirol, feldspato, potássico,pistacita, opacos e esfeno.

Textura pirociāstica

A rocha é constituīda por fragmentos de cristais e de rochas vulcānicas diversas, relati vamente bem classificadas $(0,2-0,4 \mathrm{~mm} \mathrm{em} \mathrm{me}-$ dia), com os fragmentos 17 ticos alcançado 1,0 $-2,0 \mathrm{~mm}$ no mäximo. Os grãos apresentam certo arredondamento o que parece indicar que se trata de material vulcânico com certo retraba 
1hamento. Os grãos de plagioclásio predominam amplamente sobre os de feldspato potássico.

51

$C-651$

Ignimbrito

Gran. $<0,05$ e $0,1-0,3 \mathrm{~mm}$

Quartzo, lascas de vidro, feldspato, fragmentos 1 îticos, opacos, sericita, argilo- mineral Textura pirociāstica fluidal

A rocha $\bar{e}$ composta de fragmentos de quartzo, las cas de vidro ("glass shards") e fragmentos 1it $\underline{i}$ cos (riōlito?) ambos sericitizados, com dimensões aproximadas de 0,1 a $0,3 \mathrm{~mm}$ imersos em massa finissima formada pelos mesmos componentes aglutinados. Limonita empresta à massa colo ração creme, na qual a textura fluidal e muito nîtida.

52

Riolito silicificado

Gran. $<0,1$ e $1,0-4,0 \mathrm{~mm}$

Quartzo, feldspatos, opacos, sericita, caulim. Textura porfiritica feltrosa (pilotaxitica)

Rocha contèm numerosos fenocristais $(1,0-4,0 \mathrm{~mm})$ de:feldspatos totalmente sericitizados. Os mäficos foram substituídos por opacos, sericita e caulim. Quartzo exibe corrosão magmātica.Mas sa fundamental feltrosa, porēm silicificada re sultando mosāico de grãos de quartzo imbricados por silicificação ou recristalização.

53

$K-1359$

Riolito pōrfiro (Brecha riolitica?)

Gran. 0,5-0,3 mm

Plagiocläsio; ortoclásio e quartzo

Textura porfiritica ou fragmental

A rocha é constituída por fenocristais ou frag mentos de plagioclásio e ortocläsio,e por agre gados lenticulares de plagioclāsio, ortoclásio e quartzo recristalizado em matriz de ortoclásio e quartzo esquelético, que tende a granofí rico. Apresenta sinais de recristalização pela presença de máculas quartzosas na matriz. 
54

$M-286$ $M-336$

55

56

Riolito

Gran. $<0,1$ e $3,0 \mathrm{~mm}$

Quartzo, feldspato, opacos, apatita, fluorita, clorita, epidoto, sericita e óxidos de ferro.

Textura porfiritica

Fenocristais anēdricos e subëdricos de felds pato atingem värios $\mathrm{mm}$, com contornos arredondados e corroidos, na grande maioria totalmente alterados deutericamente. A matriz é microcristalina de quartzo-feldspato, sem orientação, com sericita, grãos de ōxidos de ferro e abundante mineral opaco, clorita na forma de pequenos aglomerados.

Riolito pörfiro (brecha riolitica)

Gran. <0,1 e 0,5-3,0 mm

Plagioclásio, ortoclásio e quartzo. Secundā-. rios: epidoto e clorita

Textura porfiritica-fragmental

Plagiocläsio ocorre na forma de fenocristais ou fragmentos ou constitui agregados lenticu lares com o quartzo recristalizado em matriz rica de ortociāsio e quartzo esquelētico que tendem a exibir intercrescimento granofirico. Mostra sinais evidentes de recristalização (mäculas quartzosas na matriz).

Dacito cataciasado

Gran. $<0,1$ e $1,0-5 \mathrm{~mm}$

Plagiociásio, microclínio e quartzo.

secundārios: sericita, clorita, öxidos de ferro e argilo-mineral

Textura porfirîtica cataclāstica

os fenocristais de plagioclāsio podem alcançar atē $5 \mathrm{~mm}$, aparecem por vezes substituí dos pelo microciinio. Massa fundamental fina mente cristalina bastante orientada. 
57

$S-603$

$S-642$

58

59

$S-683$

$W I-S-21$

61
Andesito pörfiro

Gran. 0,1-0,4 e 3,0-15,0 mm

Plagioclāsio e ortociásio (50), apatita (3), biotita (2), magnetita (10), clorita (20), carbonatos (13) e quartzo (2\%).

Textura feltrosa porfiritica

Grandes fenocristais de plagiocläsio $A_{50}$ al terado em sericita compacta e com ortociásio nas bordas. Massa fundamental pilotaxitica de plagiociásio e ortoclāsio (ferruginoso) pontilhada de clorita, carbonatos e magnetita.

Brecha andesītica (?)

Gran. $0,2-2,0 \mathrm{~mm}$

Ortoclāsio e plagiocläsio. Acessōrios titani ta, apatita, opacos, quartzo.sécundärios:clo rita e hematita.

Textura fragmental

Fragmentos sericitizados e hematitizados de ortocläsio e plagiocläsio em massa fundamental fina feldspātica hematítica.

Brecha riolitica

Gran. $0,2-2,0 \mathrm{~mm}$

Feldspato, quartzo e quartzito.

Textura fragmental

Aparecem fragmentos de feldspato. (microcli nio?) e grãos redondos de quartzo e quartzito em massa finissima com quartzo recristal zado em mosáico.

\section{Riolito}

Gran. $0,05-0,08$ e $0,2-2,5 \mathrm{~mm}$

Quartzo (35), feldspato potássico (54), muscovita (1), magnetita (3). Secundärios:sericita, carbonato, limonita e hematita

Textura porfiritica

Os fenocristais são de quartzo,parcialmente corroído com coroas feldspäticas e de felds.- 
patos (provavelmente potässicos) substituỉdos em grande parte por agregados de sericita,car bonato e hematita fina. Muscovita impregnada de limonita fina nos clivagens. A massa funda mental é constituĩda por quartzo e feldspatos finos, tendendo a intercrescimentos micropegmatîticos em pseudo indivíduos maiores. Magne tita e sericita na matriz fina.

Quartzito secundārio (riolito silicificado)

Gran. 0,01 mm e menor

Quartzo (80), sericita (15), ōxidos de ferro

Textura afanītica

Agregado finissimo de quartzo.com inúmeros de agregados sericiticos e pigmentos vermelhos de hematita fina.

observa-se em um 1 ado da lämina fragmento de rocha vulcânica porfirîtica, clara, com fragmentos ou fenocristais de feldspato totalmente sericitizado e silicificado.

WI-S-157 Quartzito secundārio (tufo riolitico silicifi cado)

Gran. $0,02-0,2 \mathrm{~mm}$

Quartzo (70), sericita (25), feldspato (2), fragmentos 1 iticos (3).

Textura piroclästica

A massa principal aparenta ser de natureza clástica (piroclāstica). Essencialmente constituida de quartzo e sericita finos. Lentes alongadas tem a mesma composição conservando no entanto estruturas fluidais so visiveis em nicōis descruzados, jā que estão substituĩdos por mosáico de quartzo fino. Aparecem numero sos corpos irregulares as vezes estrelados, com evidéncias de preenchimento original do tipo colomörfico, agora tambēm substituidos por mosāico de quartzo mais grosso. Raros fenocristais e fragmentos de feldspato sericiti zado. 
64

WI $-S-192$

65

$W I-S-25 I$
Quartzito secundärio (tufo riolitico silicîficado)

Gran. $0,05-0,1$ e $0,5-2,0 \mathrm{~mm}$

Quartzo (70), sericita (25) e opacos (5).

Textura piroclästica

Massa principal brechada e fraturada essen cialmente constituída de quartzo. Os grãos maiores de quartzo $(0,1 \mathrm{~mm})$ com inclusōes de partículas sericiticas. Corpos maiores $(0,5-2,0 \mathrm{~mm})$ sericiticos aparentemente substituem feldspatos. Cubos ( secções quadradas) vazios ou parcialmente preenchi dos por limonita vermelha (hematita?). Fra turas limonitizadas e espaços preenchidos com quartzo turvo ou 1 împido e sericita.

Riolito pōrfiro

Gran. 0,02-0,04 e 0,5-3,0 mm

Quartzo (36), feldspato potāssico (25), pla gioclásio (13), muscovita (1). Secundārios sericita (20), limonita, leucoxēnio e carbonatos (5).

Acessōrios:zircão, apatita, magnetita

Textura porfirîtica fluidal

os fenocristais são de: quartzo bipiramida do as vezes tendendo a prismätico com corrosão magmática; plagioclásio albītico algo alterado em zonas sericíticas e carboná ticas, feldspato potássico compertita gros: sa e de muscovita às vezes euedral, totalmente opacificada nas partes internas. Mas sa fina ( $7.0 \%$ da rocha) quartzosa ou quartzo-feldspātica rica de sericita fina, limo nita e carbonatos, recristalizada em mosäi co na qual se vēem vestígios de textura fluidal convulcionada original.

Tufo riolitico

Gran. $0,005-0,3$ e $0,5-3,0 \mathrm{~mm}$

Quartzo, feldspato. opaco: magnetita 
Secundārios: sericita, carbonatos,

oxidos de ferro.

Textura porfirîtica ou piroclāstica

Fenocristais ou fragmentos de fenocristais de quartzo e de feldspato (pertita grosseira) o ültimo parcial ou totalmente substi tuĩdo por quartzo, sericita e carbonatos. Massa fina quartzo-sericîtica granulomētrica e texturalmente heterogēnea. Fragmentos rioliticos agrupados (aglomerados). Em tre chos a matriz é mais grosseira constituida de quartzo pavimentoso ou intercrescimentos quartzo-feldspāticos criptopegmatíticos ou esferuliticos.

Ignimbrito riolītico silicificado ("Welded Tuff")

Gran. $0,005-0,02$

Quartzo (65), sericita (30), limonita (4) e feldspato (1).

Textura pirociāstica modificada

Agregados finos quartzo-sericiticos com raros feldspatos primärios quebrados.

Pigmentos ferruginosos abundantes.

A origem pirociāstica è determinada pela presença de lascas de vidro ("glass shards") totalmente substituidas por sericita, pouco quartzo e limonita, esta segregada nas bordas. Matriz essencialmente quartzosa. Raros feldspatos clāsticos preservados, no geral totalmente sericitizados.

Dacito pōrfiro (brecha dacītica)

Gran, 0,01-0,1 e 0,5-4,0 mm

Plagioclásio (albítico)e quartzo

Acessōrios: apatita e magnetita.secundārios: clorita, epidoto, biotita verde e agregados saussuriticos.

Textura porfiritica ou fragmental 
Massa fina quartzo-feldspätica algo flujdal. e esferulitica, rodeia fragmentos e cristais eudrais de plagiocläsio albitico mais ou menos saussuritizado: Epidoto, biotita verde e quartzo são localmente abundantes na $\because$ forma de vênulas e pseudomorfos.

$68 a$

$D-217$

Andesito pōrfiro (metandesito)

Gran. 0,01-0,1 e 1-3 mm

Plagioclásio (oligoclāsio a albita)

feldspato potässico (8), quartzo (5), biotita (8), epidoto (7), magnetita (2). Acessó rios apatita, zircão, allanita. Secundārios: leucoxênio, limonita e clorita

Textura porfiritica

Mais da metade da rocha $\vec{e}$ constituida por fenocristais de pragioclásio em parte albiti zado, sericitizado e epidotizado.

Raras manchas de feldspato pertitico.

Quartzo na forma de micro e fenocristais bipiramidados

Magnetita limonitizada e leucoxenizada em planos octaédricos. Concentrações de epidoto e biotita verde em parte cloritizada. Massa fina essencialmente feldspätica ( plagjociāsio?) com muscovita, biotita, quartzo e epidoto,este em goticulas.

$68 b$

Metadacito

Gran. massa fina $0,1 \mathrm{~mm}$. Augen $1-2,5 \mathrm{~mm}$ Plagiocläsio albitico (40), feldspato potässico (15), quartzo (25), muscovita e sericita (10), magnetita (3), biotita e titanita (3), carbonatos (4)

Acessōrios e secundários: zircão, apatita e clorita

Textura blastoporfiritica (micro-augen) Plagioclásio na forma de raros cristais idio mörficos e numerosos augens, bastante serici tizados, granulados e deformados. Concentra- 
ções de biotita e magnetita. Massa fina quart zo-feldspática com faixas ramificadas de muscovita, biotita, carbonato, bem orientadas co mo em gnaisse ou mica-xisto fino. Magnetita fragmentada e leucoxenizada em planos reticulares. Rocha deformada, cataclasada e metamor foseada em baixo grau.

$68 \mathrm{c}$

$D-223$

Metadacito pórfiro

Gran. $0,04 \mathrm{~mm}$ e $1,0-3,0 \mathrm{~mm}$

Plagioclásio albítico (65), feldspato potássi co (15) quartzo (8), biotita (5), magnetita (2), epidoto (5). Acessōrios e secundārios: zircão, muscovita (sericita) apatita, limonita, leucoxénio e clorita.

Textura blastoporfiritica. Plagioclāsio recristalizado idiomōrfico com geminação comum fina e sericitização intensa ou em cristais com corrosão magmätica preservada,ou em cristais quebrados e arredondados por fricção tectōnica

Massa fundamental fina essencialmente feldpätica com algum quartzo, sericita e biotita verde, esta com nîtida isoorientação ao redor de fenociristais. Epidoto e biotita verde (mais clorita) em agregados majores pseudomör ficos de máficos.

Rocha submetida a metamorfismo brando.

Gran. fragmentos $0,2-2,0 \mathrm{~mm}$

plagioclásio, microciónio, quartzo (?), opacos, titanita, apatita, biotita verde e epidoto.

Textura porfiritica fragmental

Fenocristais fragmentados de plagioclásio albitizado e epidotizado; microclinio tambēm a terado. Massa fundamental finissima a fina de feldspato e quartzo (?) salpicada de epidoto e biotita verde. Concentrações maiores de epi doto na forma de veios. 
Siltito a arenito fino cataclástico Quartzo, feldspato, argilo-minerais, muscovi ta-sericita, opacos, żircão e leucoxēnio.

Rocha siltosa a arenosa fina, com intercalações irregulares de grãos de diferentes tamanhos (silte a areia fina), cimentados por sĩlica antigenica, com raros niveis argilosos e micáceos associados a estilólitos com opacos, veios de quartzo recristalizado e ca vidades com argilo-minerais.

$7 i$

$A M-711$

Dololutito

Carbonato (90), quartzo, opacos, muscovita sericita, colofana e feldspato (10)

Rocha carbonática, microcristalina, com grãos de quartzo, feldspato e colofana de granulação tamanho silte e areia $(0,01$ a $0,1 \mathrm{~mm})$, flutuantes na matriz carbonätica.Li thas subparalelas, delgadas de opacos.

Arenito subarcósio cataclástico

Gran. 0,1-0,5 mm

Quartzo, feldspato, fragmentos de rocha, argilo-minerais, opacos (10-15), muscovita-sericita e zircão.

Rocha arenosa, constituîda principalmente por grãos de quartzo e secundariamente de fragmentos de rocha vulcânica, opacos e sile xito, cimentados por sîlica autigênica, opa cos e argilo-minerais. Apresenta niveis, intercalações e veios cataclasados.

$74 \cdot \mathrm{JU}-02$

Arenito protoquartzitico

Gran. 0,5-0,6 mm

Quartzo (90), opacos e limonita (2), sericita (1), quartzito (7).

os contatos granulares prē-cimentação eram planos, indicando compactação mediana A cimentação ê promovida por capas de sîlica autigênica. 
75

JU-03

$N-9747-A$

77

78

NTR -13

79

NTR- 168

NTR -290

Subarcósio

Gran, 0,2-0,6 mm

Quartzo (85), quartzito e siltito (12), opacos (2), argilo-minerais (caulinita e montmorilonita) (1).

Rocha sedimentar psamitica, constituída por grãos de quartzo de 0,2-0,6 $\mathrm{mm}$ e fragmentos de quartzito e siltito, cimentados por silica autigēnica e ōxido de ferro.

\section{Cálcārio silicificado}

Quartzo, calcedōnia, opacos, limonita, carbo nato (restos)

Houve total substituição da rocha original por quartzo e calcedónia, preservando-se no entanto a estrutura sedimentar original. Tem aspecto estratificado microondulado.

\section{Calcarenito (?) silicificado}

Quartzo, żircão, carbonato, chert e sericita. Rocha muito silicificada, mas estando ainda preservados inúmeros grãos arenosos de quart zo, bem como são relativamente $\because$ abundantes restos carbonāticos na matriz. A : proporção de clásticos originalmente era elevada $( \pm 30 \%)$.

Metargilito siltoso

Quartzo, argilo-mineral, sericita, microclínio, oxidos de ferro, fragmentos liticos: Grãos de quartzo e feldspato sîticos, imersos em matriz argilosa, encontrando-se 0 conjunto todo impregnado por óxidos de fer ro. A sericita é muito abundante.

Silexito

Quartzo, calcedōnia, turmalina, sericita e argilo-mineral.

Rocha sedimentar completamente silicificada, tendo sido substituída por calcedónia e quartzo, este em vênulas. Pequenos grãos bi.r 
refringentes, com distinta diferença entre os indices extremos parecem ser restos de carbonato.

Siltito arcosiano, brechado e silicificado Gran. 0,01-0,3 mm e 0,4-0,8 mm

Maior parte da rocha $\bar{e}$ constituĩda de grânulos de quartzo envoltos por fina poeira limonitica. Disseminados na massa ocorrem grãos de feldspato sericitizado de :0,4$0,8 \mathrm{~mm}$. Esta rocha foi completamente fratu rada e brechada em fragmentos desde sub-mi 1 imëtricos a centimētricos e cimentada por quartzo secundārio.

Siltito

Gran. 0,01-0,1 mm

Fragmentos de quartzo, feldspato em grãos finos, sericita, limonita e outros,em camadas deformadas e interrompidos por material arenoso um pouco mais grosso.

Textura psamitica.

Dolomito impuro

$0,015:-0,1 \mathrm{~mm}$

Carbonato (85), quartzo, microciínio (10). Acessörios: opacos, zircão e sericita (5). 0 carbonato apresenta-se com grãos finos $(0,015 \mathrm{~mm})$ num mosáico que não preserva as estruturas originais. Os clastos são areno sos (até $0,1 \mathrm{~mm}$ ), siltosos de quartzo. e feldspato geralmente com contatos flutuantès

Estilöjitos estão presentes, assim como niveis especialmente mais quartzo-feldspäticos. 
constituĩda por grăos de carbonato tamanho silte/areia muito fina cimentados por carbo nato microcristalino, argilo-minerais e öxi dos de ferro.

Arenito ortoquartzītico

Gran. 0;13-0,26 mm

Quartzo (90), opacos (5), quartzito

observa-se intenso crescimento autigênico ao redor dos grãos de quartzo, cimentando a rocha. Quanto a textura original os grãos eram sub-arredondados e a esfericidade variava de boa a média.

Metassiltito feldspätico

Gran. 0,25-0,35 mm

Microclínio (60), quartzo (20), sericita (19)

Acessörios: turmalina, opacos, anatäsio e zircão (1).

0 feldspato e turvo devido a .impregnação por öxido de ferro; sericita é bem desenvol vida e isoorientada. 0 acomodamento gradacional coincide com a orientação das palhetas de sericita. Grau de diagēnese muito elevado. Estägio filomörfico de E.C. Dapples

Arenito ortoquartzītico

Quartzo com aguihas de rutilo (90)

opacos e limonita (5). Acessōrios: zircão e quartzito. Abundante crescimento autigēnico de quartzo, preenchendo os interstícios dos grãos.

Cimento ferruginoso,principalmente limoniti co. Os grãos originalmente eram : arredonda dos e de boa esfericidade.

Arenito ortoquartzitico

Quartzo (90), barita (2), opacos e limonita (7). Acessōrios: zircão, turmalina e quart.- 
zito (1)

Quartzo com crescimento autigēnico.

Cimento ferruginoso ( 1 imonitico) abundante

Quanto a textura original, os grãos eram arre dondados e com boa esfericidade.

WI-15A Arenito (ortoquartzito)

Gran 0,5-0,8 mm

Quartzo (90). Outros: grânuios de rochas efusi vas, feldspato (?), opacos (em acamamento), mi nerais pesados e etc. 0 quartzo apresenta crescimento autigênico

Textura psamitica

90

W I -33

Quartzito fino

Gran 0,1-0,3 (atē 0,8$) \mathrm{mm}$

Quartzo pavimentoso (98), feldspato, opacos, chert, mica alterada, 1 imonita ( $2 \%$ )

Textura granoblāstica poligonal

91

$W I-34$

Quartzito fino

Gran 0,01-0,05 mm

Quartzo (60), feldspato (grãos redondos), opa cos, limonita e etc (40)

Textura granoblāstica muito fina (meta-chert)

92

WI -35

Siltito a arenito fino

Gran 0,01-0,1 mm

Quartzo com grãos imbricados (80), feldspato (?), argilas (illita?), wavellita fibro radiada, minerais pesados, 1 imonita. Com camadas muito deformadas

Textura pelitica e psamitica

$W I-39$

\section{Arenito (ortoquartzito)}

Gran 0,2-0,4 mm

Quartzo (80). Outros: chert, Timonita, illita, minerais pesados, quartzo de crescimento secundārio (20)

Textura psamitica 
94

C -558

C -582

96

C -588

c-588

97
Mariupolito

Gran. 0,2-0,8 e 1,0-10,0 mm

Albita $A n_{5}(40)$, egirina (15) e nefelina (45). Textura traquitica, fanerítica inequigranular. A albita aparece em ripas sub-alinhadas, envoltas por cristais de egirina verde e egirina-augita, bem como por cristais milimetricocentimëtricos de nefelina.

Egirina sienito (alcali sienito)

Gran. 1,0-4,0 mm

ortoclásio pertítico, oligocläsio, egirina, riebeckita, apatita, opacos e limonita.

Textura hipidiomōrfica.

Ortoclásio pert̄̄tico e o oligocläsio aparecem intercrescidos na forma de cristais hipidio mörficos a xenomörficos. Limonita disposta preferencialmente na pertita. Egirina prismātica ou xenomōrfica, com inclusões de apatita e opacos. Riebeckita ocorre subordinada em prismas com inclusões de egirina e apatita.

Egirina sienito

Gran. 1,0-6,0 mm

Ortoclāsio (80), egirina-augita, riebéckita, magnetita e opacos (20).

Textura, "sub-ofitica"

o ortociāsio mesopertítico com forma mais ou menos retangular, tipo "tigrado", perifericamente mais albitico. Intersticialmente aparecem egirina-augita (verde vivo), fresca ou alterada em riebeckita (verde azulada).

Egirina-nefelina sienito

Gran. 1,0-5,0 mm 
Ortoclāsio pertítico (35), nefelina (35), oligoclā sio (15), egirina (10). Acessōrios:egirina-augita, biotita, titanomagnetita, ilmenita e cancrinita e apatita (5)

Textura hipidiomōrfica

o ortoclásio pertỉtico aparece geralmente intercrescido poiquiliticamente com pequenos prismas de oligoclāsio. Desenvolve-se cancrinita sobre a nefelina. Egirina forma agregados de até $3 \mathrm{~mm}$.

$98 \cdot K-1304$

Augita sienito (larvikito)

Gran. $0,5-10 \mathrm{~mm}$

Feldspato alcalino (75), augita diopsidica (10), olivina (5), biotita verde (5). Acessōrios: magnetita, apatita e serpentina secundária (5)

Textura hipidiomōrfica

Grandes cristais retangulares de feldspato alcalino um pouco pertiticos e geminados Carlsbad. Prismas algo alongados de augita diopsídica verde clara, frequentemente rodeando cristais subidiomōrficos de olivina faialītica $\left(2 v_{x}=60^{\circ}\right.$ : aprox.) levemente serpentinizada. Biotita pardo avermelhada poiquilitica,engloba total ou parcialmente mäficos, magnetita e apatita.

$98 A \quad K-1307$

Egirina sienito

Albita e ortocläsio (85), egirina (12).

Acessōrios: biotita e opacos alterados (3).

Textura "diabasōide" ofitica

Grandes cristais ripiformes de albita bastante manchados de ortociāsio turvo.

A egirina verde clara granular ocupa espaços. intersticiais nos cruzamentos das traves. A biotita $\bar{e}$ rara.

$99 \quad k-1309$

Egirina-nefelina sienito (egirina litchfieldito) Gran. $0,2-3,0 \mathrm{~mm}$

Albita (35), microclinio (15), egirina (20), nefelina (25), analcita ou sodalita (3), esfalerita e calamina (2). Acessōrios: cancrinita e hema 
tita secundāria.

Textura foiaitica (traquitōide) poiquilitica Albita em pequenas ripas geminadas em arranjo decussado, com espaços intersticiais ocupados por analcita ou sodalita, nefelina e cancrinita, microclínio capeado de albita tambēm em cristais maiores. Egirina verde e nefelina formam grandes cristais poiquiliticos. Intersticialmente aparecem esfalerita e calamina.

$100 \quad K-1312$

Microsienito alcalino

Gran. $0,1-1,0 \mathrm{~mm}$

Microclínio, quartzo, anfibōlio sōdico. (rie beckita?), egirina (?) e limonita.

Textura panxenomörfica.

Grãos equidimensionais de diāmetros variados de microclinio mesopertitico e algum quartzo. Anfibōlio sōdico presente provavelmente $\bar{e}$ a riebeckita, a qual frequentemente se associa a pseudomorfos limonitizados, possivelmente a partir da egirina.

$101 \quad k-1442$ Quartzo sienito alcalino

Gran. 2,0-10,0 mm

Feldspato alcalino (78), quartzo (5), égirina (5), arfuedsonita e riebeckita (10), magnetita (1) e zircão (1).

Textura fanerītica foia itica (traquitōide) Grandes cristais ripiformes de mesopertita, geminada segundo Carlsbad. Individualizações de microclinio e albita; o ültimo, especialmente nas bordas do feldspato alcalino e em pequenos cristais isolados. Nos espaços tri angulares forma-se quartzo equidimensional. A egirina, arfuedsonita e riebeckita associamse ofiticamente com os feldspatos. Incluidos nos mäficos aparecem magnetita e zircão. 
Egirina sienito

Gran. 1,0-3,0 mm

Feldspato alcalino (70), egirina e biotita

(28). Acessórios: fluorita, hematita, clorita e anfibölio sōdico.

Textura traquitōide

Ripas largas de feldspato alcalino sub-orien tado, geminado Carlsbad, geralmente mesopertítico (60\% Ab limpido e 40\% Or turvo), tambëm como anortocläsio ou feldspato criptopertiti co $1 \tilde{i} \mathrm{mpido}$.

Entre os máficos, biotita predomina sobre a egirina verde claro, ambos intercrescidos ou em agregados finos suborientados ou ainda in tersticiajs substituindo feldspatos nas bordas.

Agregados de clorita clara, muito fina, coro adas por hematita. Alguma fluorita intersticial.

Gran. $0,2-0,5$ e $0,5-1,5 \mathrm{~mm}$ Albita (65), nefelina (12), ortoclāsio (7), natrolita (1), egirina (15). Acessōrios:biotita, melanita, anfibōlio (?) e um mineral não identificado, pardo laranja $\left(N_{X}\right)$ e pardo verde $\left(N_{Z}\right) . N_{Z}-N_{X} \sim 0,030 ; 2 v \sim 80^{\circ} ; v>r$.

Textura "diabasōide" ou "ofítica".

Ripas ou placas de albita limpa retangular de 0,6-0,8 mm com geminação fina e um pouco irregular. Fenocristais poiquiliticos e maio res de egirina. Nefelina em cristais poiquilīticos e intersticiais. Ortocläsio intersti cial com alteração.

Anfibōlio verde laranja. Opacos raros ou escondidos em alterações pardo claras não reconhecidas e outros pardo escuros combiotita e melanita. 
Mariupolito e eudialita pegmatito

Granulação; Parte fina (feldspato e egirina) 0,5-0,8 mm; Parte grossa; albita 0,5-1,0 mm outros 2-4 mm, ègirina atē $10 \mathrm{~mm}$

Parte fina: ripas ou placas de albita limpa, retangular, geminação fina e um pouco irregular, egirina (23) xenomorfa, nefelina (10) poiquilitica e intersticial. Anfibolio pardo verde laranja (?) e opaco raro ou escondido em alterações pardo claros não re conhecidas e outros pardo escuros. (2). Ace sōrios: biotita, melanita, eudialita-eucolita.

Parte grosseira: grandes cristais poiquiliti cos de nefelina (20) sericitizada, egirina clara (30), albita (20) e eudialita-eucolita rosa (15), buchos de minerais granulares poligonais incolores (não identificados) associados a eudialita ou nefelina.

Latito (mela-sienito pörfiro) - Tusitanito Gran. $0,2-0,6$ e $3,0-10,0 \mathrm{~mm}$ Plagiocläsio e ortoclāsio (60) augita biotita (5) magnetita (10). Acessōrios e secundārios, apatita, clorita e nontronita. Textura "diabāsica" porfirītica Grandes e raros fenocristais de plagioclasio $A_{50-20}$ em massa intersticial rica em ripas e retāngulos de oligoclāsio $\left(2 v \times-40^{\circ}\right)$ e feldspato alcalino em textura diabásica com augita incolor granular idiomörfica,bio tita (verde-vermelha)e magnetita granular.

Latito-jusitanito

Gran. 0,25-0,50

01 igocläsio, ortocläsio, clinopiroxénioldiop sídio), opacos, argilo-mineral (nontronitamontmorilonita) e apatita.

Textura sub-ofïtica (diabäsica) 
0 oligoclásio e o ortoclásio formam ripas e retāngulos.

0 diopsidio se altera formando biotita, argi10-minerais e carbonatos.

Latito

Gran. 0,25-0,50 e 4-5 mm

Ortoclāsio, clinopiroxēnio, plagioclāsio e opacos. Acessōrio: apatita.

Secundārios: biotita, argilo-mineral (montmorilonita?), carbonatos, quartzo e zeolitas.

Textura granular idiomōrfica.

Feldspato predominante é o oligoclásio com häbito tabular. Plagioclāsio é mal maclado, 0 piroxēnio (diopsīdio?) ē abundante e apresenta-se bastante alterado em biotita, argilo-mi nerais e carbonatos. A rocha apresenta intensa e generalizada alteração hidrotermal manifesta pela formação de argilo-minerais, ōxidos de ferro, quartzo, carbonatos, e zeolita sobre mäficos e feldspatos.

Gran. 01-0,3 mm

Ortoclāsio, albita, nefelina, egirina, arfvedsonita e biotita. Acessōrios e secundārios:opacos e natrolita.

Textura traquitica.

Ortoclāsio e albita ripiformes, sub-orienta dos, por vezes intercrescidos.

Intersticial e poiquiliticamente. nefelina em parte substituida por analcita ou sodalita.

Egirina verde amarelo claro, arfvedsonita ver de escura, biotita parda rara, natrolita secundāria em veios.

110 WI-132. Traquito pörfiro (microsienito)

Gran. 0,1-0,5 e 2,0-3,0 mm

Feldspato (70) e biotita (restos). Secundários: clorita (20), opacos, hematita e magnetita e 
etc (10)

Textura feltrosa porfiritica.

Raros fenocristais de feldspato com poeira he matitica. A massa da rocha e constituida por feldspato "enferrujado" em ripas desorientadas, (oligoclāsio ou ortocläsio), opacos, além da hematita e magnetita, clorita comum intersticial, provēm da biotita verde.

111

WI-418 Fonōlito

Gran.0,05-0,2 mm

Ortoclāsio e albjta (50); nefelina e sodalita (20), egirina-augita (20), biotita, fersmanita

e enigmatita (rara) (8)

Secundārios: ōxido de ferro (2)

Textura traquĩtica

Ripas formadas por fibras intercaladas de ortocläsio e albita,que se sub-orientam em feixes rodeando a nefelina e sodalita alterada parcialmente, egirinamaugita capeada por egirina intersticial. Areas poiquiliticas de biotita fibrosa e oxido de ferro, rodeiam a fersmanita.

Gran.

Feldspato-k, plagioclásio, piroxênio (augita egirinica e augita), quartzo, opacos, carbonatos, apatita, argilo-mineral (montmoriloni ta?)

Textura porfiritica

Fenocristais anēdricos de feldspato potássico, plagioclásio e piroxênio alterados e quartzo imersos em matriz fina holocristalina. A matriz e composta essencialmente de feldspato e micrōlitos de opacos e piroxênio, possuindo textura traquitica. 0 quartzo e pouco abundante.' 
$112 a$ Quartzo latito porfiritico

Gran massa fundamental $0,005 \mathrm{~mm}$, fenocristais: 1-2 mm

Plagiociásio: (28), quartzo (2), feldspato potássico (10).

Massa fundamental quartzo feldspätica (60) Acessōrios: biotita e magnetita. Secundärios: sericita e leucoxênio.

Textura porfiritica afanitica.

os fenocristais são constituídos por: 1 . plagioclásio algo sericitizado, bem gemina do em grãos idiomorfos ou quebrados e arre dondados. 2. Feldspato potässico (muito sō dico) mesopertîtico, em grãos tambēm quebrados. 3. Quartzo em raros cristais bipiramidados algo arredondados e deformados. Biotita pardo suja com corrosão magmätica evidente em alguns fenocristais. Massa fun damental formada por manchas irregulares de intercrescimentos finissimos de quartzo e feldspatos e por lentes quartzosas.

$112 b$

$D-283$

Arfuedsonita-quartzo latito

Gran. 0,02-0,1 mm e 0,5-2,0 mm Feldspato potássico (30), plagioclásio (al bitico) (30), quartzo (30), arfvedsonita, (8). Acessōrios: biotita, apatita, zircão

(?) titanita, magnetita. Secundärio: leuco xênio

Textura porfiritica cataclasada

Feldspato potássico, microciinnio fortemente pertitico (em manchas irregulares) cons titui os fenocristais maiores. Enquanto os médios são de plagioclásio mais ou menos sericitizados.os fenocristais menores cons tituidos por quartzo estão muito quebrados e deformados. A massa fundamental quartzofeldspätica está fortemente lineada por agulhas de arfvedsonita (pleocroismo em azul celeste e violeta). Grumo de quartzo 
arfvedsonita e algumas biotitas pardas

$112 \mathrm{c}$

$D-289$

Metalatito pōrfiro

Gran.0,04-0,1 e 1,0-5,0 mm

Plagiociāsio albỉtico (50), feldspato potássico (20), quartzo (10), biotita (10). Acessörios apatita e magnetita. Secundārio: epidoto e zeolita (10), leucoxēnio e sericita. Textura porfiritica afantica

Cerca de $30 \%$ da rocha são constituĩdos por fenocristais de plagiocläsio albitico idiomorfo ou fragmentado, isolado ou aglomerado e subdividido, sericitizado e epidotizado. Feldspato potāssico em leques divergentes (a tē $1 \mathrm{~mm}$ ) na matriz. Matriz com trama complexa fina, quartzo-feldspätica e zeolïtica,com textura fluidal e xistosa. 0 quartzo ocorre disseminado. A biotita e parda, bem orientada, dā leve xiștificação ao conjunto. Epidoto disseminado, substitui mäficos em pseudomorfos. Rocha com evidentes sinais de ...metamorfismo brando.

$113 \quad L-1274 \quad$ Metadiabäsio

Gran. $0,5-3,0 \mathrm{~mm}$

Plagioclásio (50), augita (30), olivina (10), magnetita $(10)$. Secundārios: nontronita

Textura ofitica.

Plagioclásio ripiforme sericitizado, envolto por augita. 0livina alterada isolada e in tersticial. Nontronita substitui olivina.

114 MV-05 Olivina diabāsio alcalino

Gran. $0,2-0,3$ e 2,0-3,0 mm

Plagiociásio $A n_{40}$ e ortoclásio (40), augita (30), magnetita (15) olivina e nontronita (15).

Textura ofitica.

Ripas de plagioclásio mais ou menos manchado englobados por grandes cristais esqueliticos, 
115

MV -06

Gabro

Gran. 0,5-1,5 mm

Plagioclāsio $A n_{50}(50)$, augita diopsīdica(30), hiperstēnio (10), opacos (10).

Textura Intergranutar a sub-ofitica.

Muita uralita nos piroxênios, evidenciando hi drotermalismo ou autometamorfismo.

$115 a$ HEP-95 Piroxēnio-anfibolito feldspätico Microclinnio (40) hornblenda (40), plagiocläsio $\mathrm{An}_{30}$ (10) esfeno (2), clinopiraxēnio(5), quartzo ( $\leq 5)$. Acessōrio: allanita.

Textura granoblästica-hipidiomōrfica.

os cristais de hornblenda comum são hipidiomörficos, prismäticos e curtos. o microci $\vec{i}$ nio ocorre em cristais bem maclados, extrema mente irregulares, poiquiliticos englobando as demais fases minerais. Plagioclāsio $\bar{e}$ idio-hipidiomórfico. o clinopiroxēnio aparece como nücleo e restos dentro da hornblenda, raramente em cristais isolados. 0 quartzo $\bar{e}$ anēdrico, intersticial e com extinção normal.

$175 b$ HEP-104 Gabromelanocrätico (piroxenito)

Gran. 0,05-0,1 mm

Plagiocläsio e saussurita,hornblenda, tremolita e actinolita, esfeno, clinopiroxênio, pistacita e quartzo variāveis.

Rocha constituida fundamentalmente por uma massa de cristais de piroxēnio e anfibólio,e por quantidades subordinadas de plagioclásio, alēm da pistacita e quartzo. 0 plagioclásio é mal maclado, zonado e em parte saussuritizado. 
116

NP36 Diabäsio

Gran. 0,3 - 1,2 mm

Plagioclásio An $40-60$ (45), augita .titanifera (30), olivina (5), opacos (10). Mesōstase com uralita, feldspato, piroxēnio e apatita (10).

Textura intergranular.

Plagiocläsios idiomórficos ripiformes.

A olivina alterada em filossilicato verde. No concentrado mesostático piroxēnio na forma de grãos e a apatita na de aguihas.

$12 \dot{0}$ S-685 Gabro

Gran. $1,0-3,0 \mathrm{~mm}$

Augita, plagioclásio (andesina-labradorita), serpentina, clorita, sericita, quartzo, epidoto, apatita e opacos.

Textura intergranular localmente glomeroporfiritica

Augita ocorre em.cristais isolados de $1,0 \mathrm{~mm} e$ agregados de atē $3,0 \mathrm{~mm}$. Os plagioclásios estão em geral transformados em epidoto e serici ta. A apatita forma prismas alongados de at $\overrightarrow{\mathrm{e}}$ $1,0 \mathrm{~mm}$. 0 restante da rocha è constituído de agregados irregulares de clorita serpentina,epidoto formados por alteração deutērica de olj vina e hiperstênio (?), ou da mesostases intersticial. A ilmenomagnetita foi parcialmente alterado para leucoxēnio, conservando lamelas de magnetita. 0 quartzo aparece intersticia 1 mente em porcentagem inferior a $2 \%$.

$121 \quad S-753 \quad 01$ ivina gabro

Gran. $0,5-10$

Plagioclāsio $\mathrm{An}_{50}$ (60), titanoaugita (20), oli vina (7), magnetita (10), nontronita, mesōstases feldspātica ou zeolitica (3).

Textura ofitica.

Plagiocläsio ripiforme envolto por grandes cristais ofiticos de titanangita. 01ivina fres ca isolada, intersticial ou inclusa em titanau gita. 
Gabro (hidrotermalizado)

Gran. $0,5-3,0 \mathrm{~mm}$

Hornblenda (40), clinozoizita (37), plagioclásio (5), microclínio-pertita (15) e quartzo (3).

Textura blastogranular

A hornblenda é verde, a clinozoizita forma agregados que substituem o plagioclásio em āreas retangulares.

Aparecem restos de plagiociásio e microclīnio pertita.

$122 a$

$W I-J-8 A$

Gabro milonitico

Gran. 0,5-2,0 mm

Plagioclásio (50), hornblenda verde (48).

Acessórios: titanita, biotita, epidoto e quartzo (2).

Textura mortar

o plagioclāsio (oligoclāsio?) e a hornblenda formam um agregado de cristais deformados e arredondados, contornados por massa milonitica fina.

123

WI-S-237 01ivina basalto (mugearito?)

Gran. 0,05-0,2 e 0,2-0,6 mm

Plagioclásio (65), clinopiroxênio 25, magne tita (5), olivina alterada (2), mesostasis, (2).

Textura pilotaxitica porfiritica.

0 plagiociásio (oligoclásio) aparece na for ma de ripas isoorientadas, o clinopiroxénio limpido, incolor em grãos equidimensionais, que tendem a se aglomerar. Fenocristais de clinopiroxênio e olivina; esta ūitima está totalmente alterada em carbonatos e clorita.

124

WI-S-306 Basalto

Gran. 0,02 - 0,05 mm

Plagioclāsio (45), clinopiroxênio (40), oli- 
vina (2), magnetita (6). Secundārios: siderita, limonita e carbonatos.

Textura pilotaxitica.

A rocha è essencialmente uma massa homogê nea muito fina, composta de plagioclásio alterado(andesina-labradorita) em ripas sub-orientadas, grânulos de magnetita e clinopiroxēnio augitico, raros fenocris tais de olivina magnetitizada, carbonatizada e serpentinizada e por pequenos corpos de material pardo (1imonita e siderita?) resultantes de alteração de algum má fico (pigeonita? olivina?).

\section{Diabāsio}

Gran. $<0,5$ e $1,0-3,0 \mathrm{~mm}$ Plagioclásio (55), clinopiroxēnio (20). , magnetita (8), apatita (1), quartzo (1). Secundärios: sericita, clorita e leucoxênio.

Textura intergranular.

Ripas de plagioclásio albitizado muito al terado em sericita e clorita. Grānulos e alguns prismas maiores de clinopiroxēnio augitico incolor, por vezes muito fratura dos e alterados em substância fibrosa parda. Magnetita em grānulos pequenos,por vezes leucoxenizados. Intersticialmente e substituindo minerais primários aparece clorita verde clara, associada a algum quartzo, apatita e leucoxēnio. 
127

128

129

WI $-S-471$

130

$W I-S-481$

$W I-S-469$
Olivina diabásio

Plagioclásio, clinopiroxênio, olivina,clo rita e opacos.

Textura ofitica e intergranular Plagioclāsio ocorre em ripas jnclusas no clinopiroxentio, bem como, em cristais bem desenvolvidos e zonados junto com clinopi roxēnio intersticial

0livina serpentinizada, por vezes envolta por clorita.

Diabāsio glomeroporfirítico

Clinopiroxênio, plagioclásio, olivina (serpentinizada), opacos e sericita

Textura glomeroporfiritica

Piroxênios grandes poiquiliticos com inclusões de plagioclásio em ripas, levemen te sericitizados formam agregados em matriz subofitica mais fina.

Basalto porfiritico (glomeroporfíritico) Gran. 0,5-0,6 mm

Plagioclásio, clinopiroxênio, olivinalser pentinizada), opacos carbonato, $:$ vidro (criptocristalino)

Textura glomeroporfiritica

Fenocristais de plagioclásio zonado e oli vina formam agregados em massa : fundamen tal com textura intersectal constituida de ripas de plagioclásio, clinopiroxênio, vidro (criptocristalino) opacos e carbona to:

0livina basalto

Plagioclásio, clinopiroxênio, olivina, opacos, feldspato potássico (?), feldspatóide (?), perovskita, opacos argilo-mine rais e clorita.

Textura intergranular em parte pilotaxiti ca. 
131

$W I-S-493$

WI -S -511

132

133

YRN -2339

$D-273$
Plagioclásio ripiforme por vezes isoorien tado apresenta albitização nas bordas.01 i vinas frescas, ao lado de outras envoltas por anëis de serpentina.

Basalto

Plagioclásio, clinopiroxênio, olivina, mag netita, vidro e opacos.

Textura pilotaxitica

Plagioclásio em ripas finas orientadas, sub-paralelos em matriz.

Dìabāsio

Plagioclásio, clinopiroxēnio, olivina,opa cos e clorita

Textura subofitica

Ripas de plagiociāsio parcialmente inclü das no clinopiroxēnio. olivina em cristais subëdricos inalterados.

Metadiabäsio

Gran. 0,2-0,8 mm

Plagioclásio (40), uralita (40), epidoto (10), quartzo e biotita (10)

Textura blasto-subof $\overline{t i c a}$.

plagioclásio (01igociäsio) ripiforme, mais ou menos epidotizado. Agregados uraliticos de hornblenda capeados por actinolita e algum epidoto. Quartzo e biotita em con centrações.

Metabasito

Gran.

Plagioclāsio An 46 (50), hornblenda (35), biotita (10), epidoto (2), magnetita e 1eucoxênio (3). Acessōrios: apatita,quart zo e pirita. Secundärios: sericita e clori ta.

Textura blastofitica 
Plagioclásio turvo em parte albitizado, sericl tizado e albitizado, em ripas com geminação complexa. Piroxēnios originais totatimente transformados em agregados de cristais de dimensões variadas de hornblenda verde (mais cla ra no centro).

Biotita em plaquetas pardas, associa-se a horn blenda. Magnetita totalmente transformada em leucoxēnio granular. Epidoto espalhado. Apatita em agulhas. Rocha derivada de metamorfismo brando sobre diabāsio.

\section{Metabasito}

Gran. 0,5-1,0 mm

Plagiocläsio $\mathrm{An}_{35}(40)$, hornblenda (40), quartzo (5), biotita (5), magnetita (5) e epidoto (5). Textura blastofitica.

Plagioclásio (andesina) levemente turvo, em ripas por vezes contornadas de plagiociäsio mais sōdico e quartzo em interstîcios. Os mäfí cos originais foram substituidos : totalmente por hornblenda heterogēnea em termos de cor e granulação; os cristais maiores são verde páli dos ou pardacentos coroados por hornblenda mais verde (Y) e azul (Z). A hornblenda ocorre tambēm em agulhas e corpos informes.Concentrações de biotita fina, parda. Cristais esparsos de epidoto e magnetita.

136a TRN-F5(15) Arenito 1itico mosqueado (manchas de arenito) Gran. 0,07-0,5 mm e $1,0-1,5 \mathrm{~mm}$

Quartzo, fragmentos de rocha vulcānica e de silexito, feldspato, opacos, turmalina, muscovita-sericita, leucoxênio e material limonitico

Textura psamītica-ciàstica

Rocha arenosa, constituĩda de grānulos de quartzo, fragmentos de rocha vulcānica e sile$x$ ito de granulação variada $(0,07$ a $0,5 \mathrm{~mm})$; sub angulosos a subarredondados com contatos pla- 
nos o cimento $\bar{e}$ autigēnico limonitizado, com manchas claras de arenito em grānulos $(1,0-1,5 \mathrm{~mm})$ mesma composição, menos alterados e com cimento micáceo (não $1 \underline{j}$ monĩtico). 0 pacos não forma de grãos dis seminados nos fragmentos de rochas vulcânicas.

TRN-F5(89) Arenito protoquartzitico

Gran. 0,2-0,6 mm

Quartzo, muscovita-sericita, opacos,zir cão, fragmentos lîticos e feldspato. Textura psamītica clästica.

Rocha arenosa, constituîda de grãos, principalmente de quartzo e secundariamente por fragmentos de arenito e de ro cha vulcānica alterada, cimentados por crescimento autigēnico, ou por material fino micāçeo. Observam-se antigos contornos sub-arredondados dos grãos.Raros opacos, em gräos ou disseminados...nos fragmentos de rocha ou ainda no cimento siljcoso autigênico.

Gran. 2,0-20 $\mathrm{mm}$

Quartzo, feldspato, opacos, muscovita.sericita, silica microcristalina e argi 10-minerais.

Textura clástíca

Rocha constituĩda de seixos e grãos mi limétricos a centimétricos de arenito fragmentos de rochas vulcānicas ācidas, siltito, arenito de granulação mëdia e silexito, com contatos planos e raramen te soldados por grãos de quartzo de ta manho areia. 
$136 \mathrm{~d}$

TPN-F5(56)

$T R N-F 5(30)$

$136 \mathrm{e}$
Arenito conglomerätico

Gran. 0,1-0,5 e 5,0-20,0 mm

Quartzo, feldspato, carbonato, opacos,

fragmentos 17 ticos, leucoxēnio, argilo -mineral verde.

Textura clàstica

Rocha constituĩda de grãos submilimē tricos $(0,1-0,5 \mathrm{~mm})$ de quartzo,feldspa to fragmentos de rocha vulcânica e are nito, com contatos planos ou com cimento micáceo e carbonātico, e por grãos majores milimētricos a centimētricos de mesma constituição anterior, subanguiosos a subarredondados.
Brecha arentica

Quartzo, feldspatos, fragmentos 1 iticos, opacos, turmalina, zircão leucoxê nio, argi1o-minerais, muscovita-serici ta, argilo-mineral verde

Textura clästica

Rocha brechōide constituída de arenito com grãos de tamanho variado de quartzo e secundariamente por feldspatos e fragmentos de rocha vulcānica. Matriz carbonätica e argilosa (sub-grauvaca fina a mëdia), com fragmentos cjaros de arenito 13 tico carbonātico (fragmen tos de rocha vulcānica). Manchas de arenito lítico micäceo ocorrem nos 


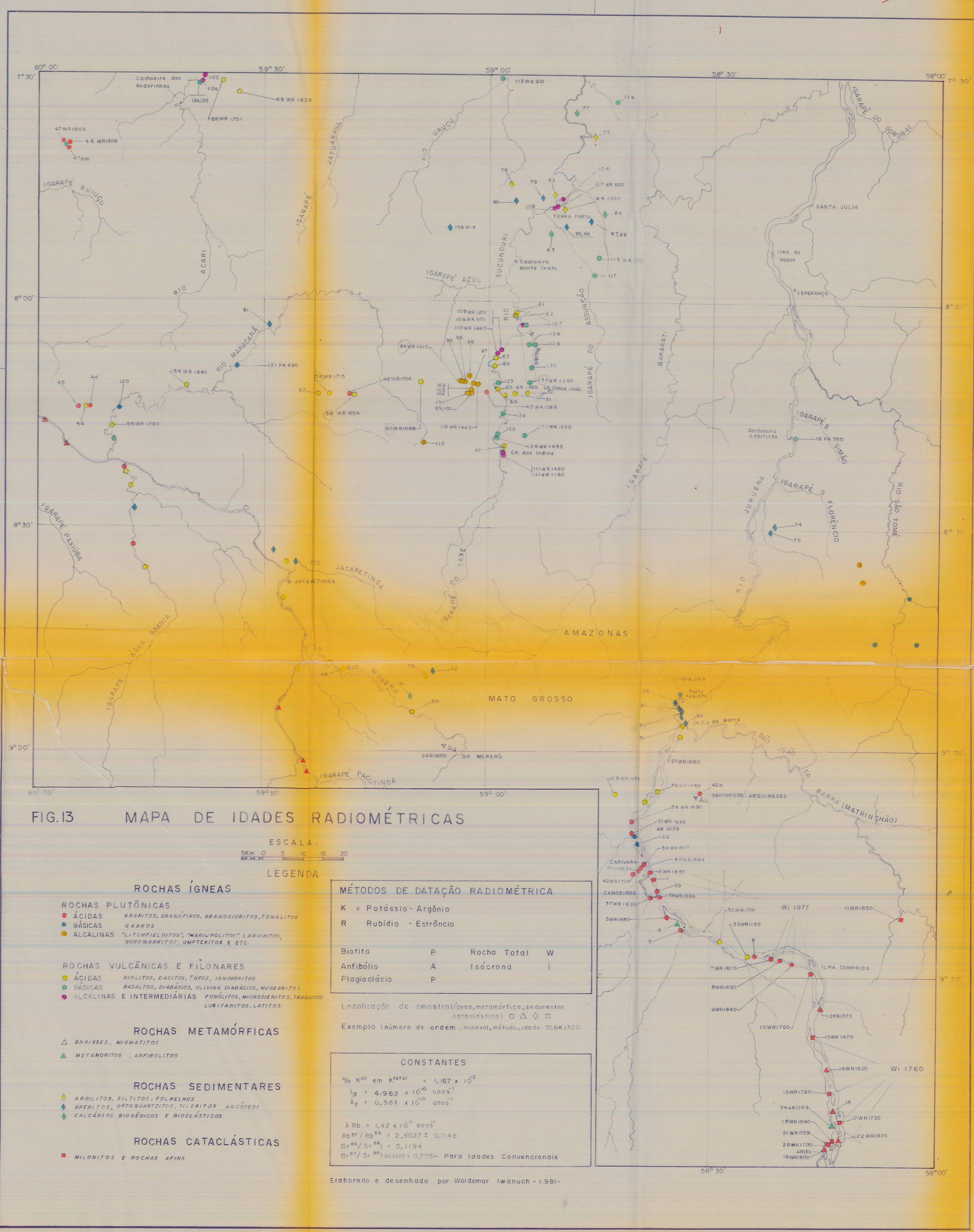




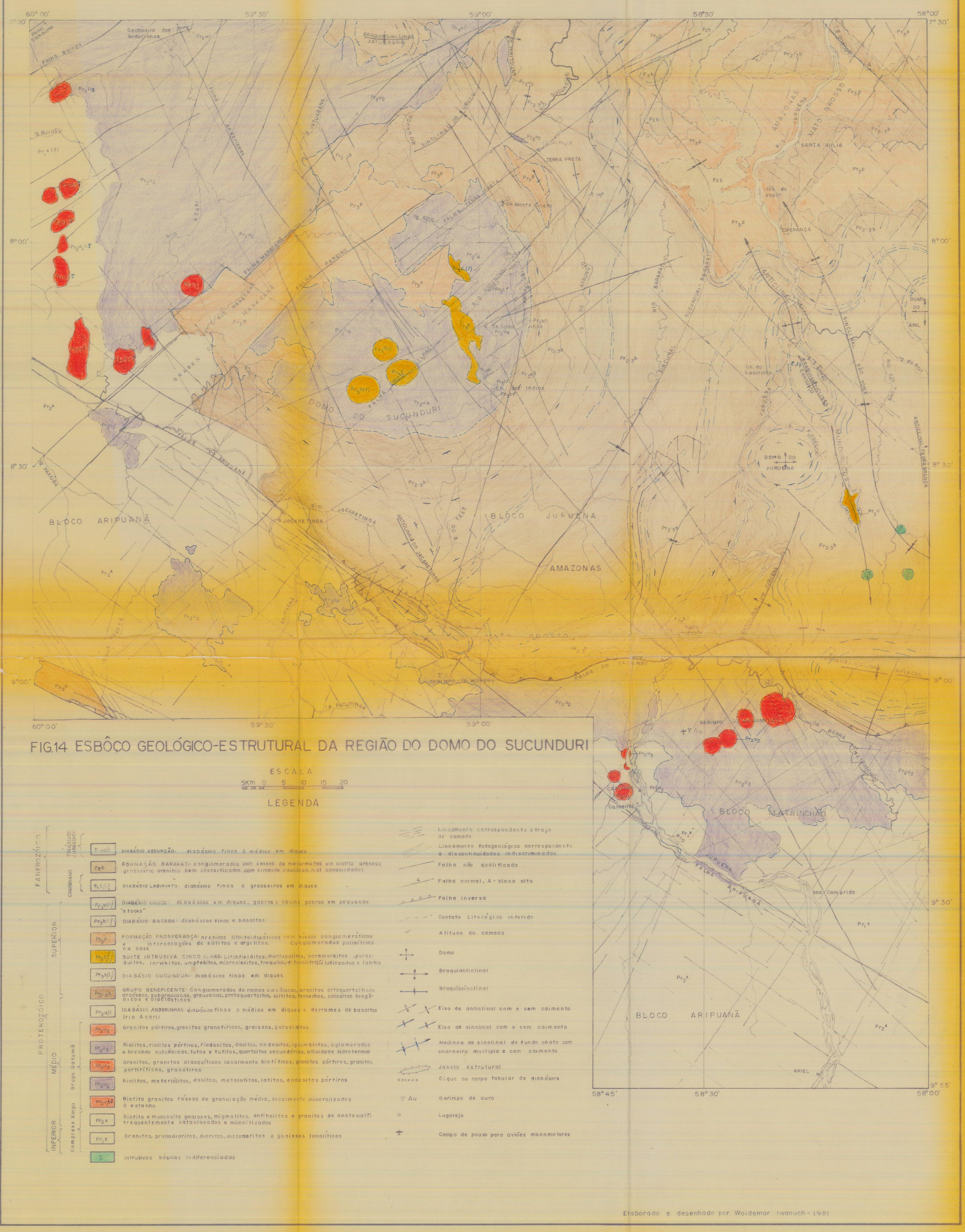

